\title{
SAZONALIDADE, REFRIGERAÇÃO E DIFERENTES TIPOS DE RECOBRIMENTO NA CONSERVAÇÃO PÓS-COLHEITA DE ESTACAS DE CORDILINE (Cordyline rubra Hügel)
}

\author{
NELSON MAMORU SAKAMOTO
}

\author{
Dissertação apresentada à Escola Superior de \\ Agricultura "Luiz de Queiroz", Universidade de São \\ Paulo, para obtenção do título de Mestre em \\ Agronomia, Área de Concentração: Fitotecnia.
}

P I R A C I C A B A

Estado de São Paulo - Brasil

Abril - 2005 


\title{
SAZONALIDADE, REFRIGERAÇÃO E DIFERENTES TIPOS DE RECOBRIMENTO NA CONSERVAÇÃO PÓS-COLHEITA DE ESTACAS DE CORDILINE (Cordyline rubra Hügel)
}

\author{
NELSON MAMORU SAKAMOTO \\ Engenheiro Agrônomo
}

Orientador: Prof. Dr. ROBERVAL DE CÁSSIA SALVADOR RIBEIRO

\begin{abstract}
Dissertação apresentada à Escola Superior de Agricultura “Luiz de Queiroz”, Universidade de São Paulo, para obtenção do título de Mestre em Agronomia, Área de Concentração: Fitotecnia.
\end{abstract}

P I R A C I C A B A

Estado de São Paulo - Brasil

Abril - 2005 
Dados Internacionais de Catalogação na Publicação (CIP) DIVISÃO DE BIBLIOTECA E DOCUMENTAÇÃO - ESALQ/USP

Sakamoto, Nelson Mamoru

Sazonidade, refrigeração e diferentes tipos de recobrimento na conservação póscolheita de estacas de cordiline (Cordyline rubra Hügel) / Nelson Mamoru Sakamoto. - Piracicaba, 2005.

63 p. : il.

Dissertação (Mestrado) - - Escola Superior de Agricultura Luiz de Queiroz, 2005. Bibliografia.

1. Ambiente protegido (Plantas) 2. Comércio exterior 3. Estacas (Plantas) 4. Fisiologia pós colheita 5. Liliaceae 6. Planta ornamental 7. Refrigeração I. Título

CDD 635.934324

"Permitida a cópia total ou parcial deste documento, desde que citada a fonte - O autor" 
Ao meu pai, Sizuo Sakamoto (in memoriam).

Dedico

Aos meus avós, Elza e Luiz Fukuda, à minha mãe, Sueli Fukuda, à minha esposa Cristina Sakamoto (que sempre me incentivou), aos meus irmãos Arison e Priscila e outros familiares pela força, ajuda e carinho.

Ofereço 


\section{AGRADECIMENTOS}

Agradeço a todos que contribuíram para a realização deste trabalho, em especial:

- À Gloriosa Escola Superior de Agricultura "Luiz de Queiróz" (ESALQ), Universidade de São Paulo (USP), pela oportunidade concedida;

- Ao Prof. Dr. Roberval de Cássia Salvador Ribeiro, pelo incentivo, orientação e amizade;

- $\quad$ Ao Centro de Raízes e Amidos Tropicais (CERAT) - Universidade Estadual Paulista "Júlio de Mesquita Filho" (UNESP) pelo apoio técnico;

- À Profa. Dra. Marney Pascoli Cereda, pelo fornecimento do amido e apoio técnico;

- À Plantas Exóticas do Brasil Agri Floricultura Ltda. pelo fornecimento do material vegetal e apoio técnico;

- Ao Departamento de Produção Vegetal;

- À Profa. Dra. Sônia Maria De Stefano Piedade, pelo orientação nas análises estatísticas;

- À secretária Luciane A. Lopes Toledo;

- A todos os funcionários do Departamento de Produção Vegetal, pelo auxílio prestado;

- Aos Ex-moradores e moradores da República Pinga Pura, uma grande família;

- À Engenheira agrônoma Helena Emi Kavamura;

- Ao Engenheiro agrônomo Sérgio K. Tanioka;

- Aos amigos e colegas do curso de pós-graduação e;

- A todos, que direta ou indiretamente contribuíram para a conclusão deste trabalho. 


\section{SUMÁRIO}

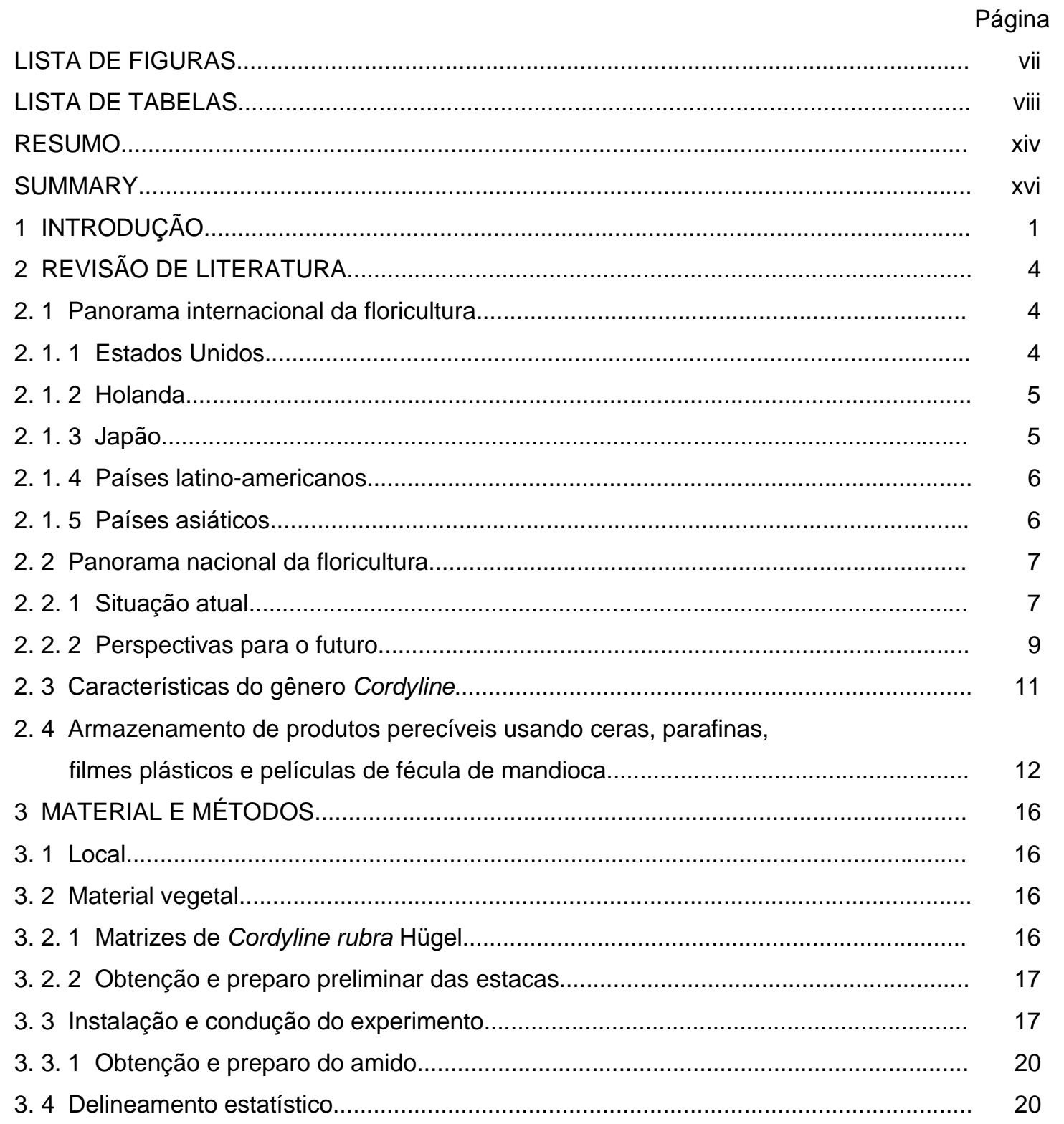




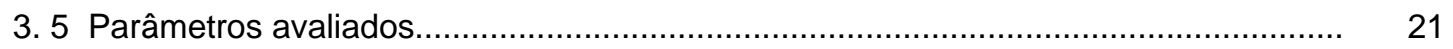

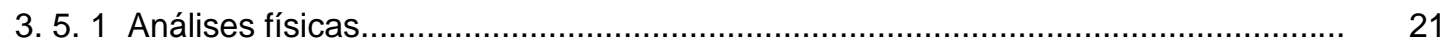

3. 5.2 Análises estatísticas.................................................................................. 22

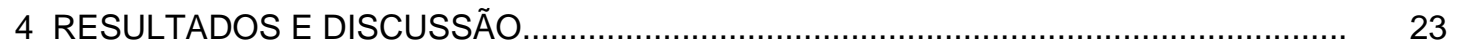

4. 1 Estacas obtidas na primavera ................................................................... 23

4. 1. 1 Desenvolvimento de parte brotos, raízes e formação de rizomas.......................... 23

4. 1. 2 Valores médios de número, massas de matéria fresca e seca de brotos, raízes e rizomas................................................................................ 26

4. 1. 3 Relação entre condições e períodos de armazenamento................................... 33

4. 1. 4 Relação entre condições de armazenamento e tipos de recobrimento.................... 36

4. 1. 5 Relação entre tipos de recobrimento e períodos de armazenamento..................... 38

4. 2 Estacas obtidas no outono........................................................................ 40

4. 2. 1 Desenvolvimento de parte brotos, raízes e formação de rizomas........................... 40

4. 2. 2 Valores médios de número, massas de matéria fresca e seca de brotos, raízes e rizomas.............................................................................. 43

4. 2. 3 Relação entre condições e períodos de armazenamento....................................... 49

4. 2. 4 Relação entre condições de armazenamento e tipos de recobrimento.................... 51

4. 2. 5 Relação entre tipos de recobrimento e períodos de armazenamento.................... 53

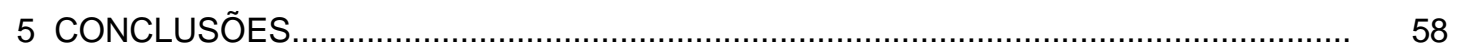

5. 1 Estacas de C. rubra obtidas na primavera.................................................. 58

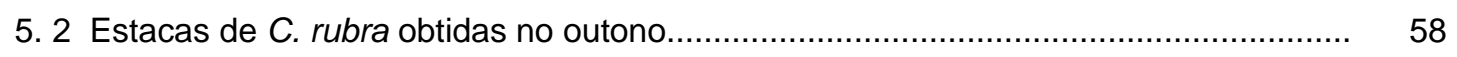

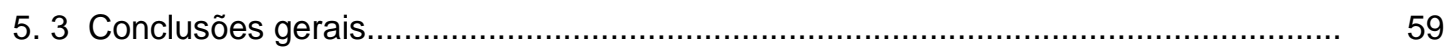

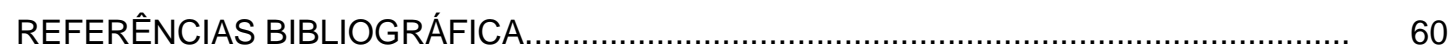




\section{LISTA DE FIGURAS}

Página

1 Exposição de mudas (esq.) e de plantas envasadas (dir.) de dracenas e cordilines na IPM (Internationale Pfanzenmesse) Essen/Alemanha.

2 Aspecto geral do matrizeiro de C. rubra.

3 Tipos de recobrimento de estacas de C. rubra. Da esquerda para a direita; FE-Fécula de mandioca; PV-Parafina no ápice e vermiculita na base; PA-Parafina no ápice; SP-Saco plástico; e SR-Sem recobrimento.

4 Fluxograma de preparo da suspensão e produção de filme amiláceo, a partir do amido natural.

5 Aspecto de plantas de C. rubra, retiradas do leito de enraizamento, após 90 dias, para análises físicas, com detalhe dos rizomas à direita 


\section{LISTA DE TABELAS}

1 Percentual do desenvolvimento de brotos, raízes e rizomas em estacas de primavera de C. rubra, armazenadas por 30, 60, 90 ou 120 dias, em condições de temperatura ambiente ou refrigerada e submetidas aos diferentes tipos de recobrimento

2 Médias do número de brotos desenvolvidos em estacas de primavera de C. rubra, armazenadas por 30, 60, 90 ou 120 dias, em condições de temperatura ambiente ou refrigerada e submetidas aos diferentes tipos de recobrimento.

3 Médias das massas de matéria fresca de brotos, em gramas, desenvolvidos em estacas de primavera de $C$. rubra, armazenadas por 30, 60, 90 ou 120 dias, em condições de temperatura ambiente ou refrigerada e submetidas aos diferentes tipos de recobrimento.

4 Médias das massas de matéria seca de brotos, em gramas, desenvolvidos em estacas de primavera de $C$. rubra, armazenadas por 30, 60, 90 ou 120 dias, em condições de temperatura ambiente ou refrigerada e submetidas aos diferentes tipos de recobrimento

5 Médias dos números de raízes desenvolvidas em estacas de primavera de C. rubra , armazenadas por 30, 60, 90 ou 120 dias, em condições de temperatura ambiente ou refrigerada e submetidas aos diferentes tipos de recobrimento. 
6 Médias das massas de matéria fresca de raízes, em gramas, desenvolvidas em estacas de primavera de C. rubra, armazenadas por 30,60, 90 ou 120 dias, em condições de temperatura ambiente ou refrigerada e submetidas aos diferentes tipos de recobrimento.

7 Médias das massas de matéria seca de raízes, em gramas, desenvolvidas em estacas de primavera de $C$. rubra, armazenadas por 30, 60, 90 ou 120 dias, em condições de temperatura ambiente ou refrigerada e submetidas aos diferentes tipos de recobrimento.

8 Médias dos números de rizomas desenvolvidos em estacas de primavera de C. rubra, armazenadas por 30, 60, 90 ou 120 dias, em condições de temperatura ambiente ou refrigerada e submetidas aos diferentes tipos de recobrimento.

9 Médias das massas de matéria fresca de rizomas, em gramas, desenvolvidos em estacas de primavera de C. rubra, armazenadas por 30, 60, 90 ou 120 dias, em condições de temperatura ambiente ou refrigerada e submetidas aos diferentes tipos de recobrimento.

10 Médias das massas de matéria seca de rizomas, em gramas, desenvolvidos em estacas de primavera de C. rubra, armazenadas por 30, 60, 90 ou 120 dias, em condições de temperatura ambiente ou refrigerada e submetidas aos diferentes tipos de recobrimento.

11 Médias do número de brotos desenvolvidos e suas respectivas massas de matéria fresca e seca, em gramas, em estacas de primavera de C. rubra, armazenadas por 30, 60, 90 ou 120 dias, em condições de temperatura ambiente ou sob refrigeração.

12 Médias do número de raízes desenvolvidas e suas respectivas massas de matéria fresca e seca, em gramas, em estacas de primavera de C. rubra, armazenadas por 30,60, 90 ou 120 dias, em condições de temperatura ambiente ou sob refrigeração. 
13 Médias do número de rizomas desenvolvidos e suas respectivas massas de matéria fresca e seca, em gramas, em estacas de primavera de C. rubra, armazenadas por $30,60,90$ ou 120 dias, em condições de temperatura ambiente ou sob refrigeração.

14 Médias do número de brotos desenvolvidos e suas respectivas massas de matéria fresca e seca, em gramas, observados em estacas de primavera de $C$. rubra, tratadas com 5 tipos de recobrimento e armazenadas em condições de temperatura ambiente ou sob refrigeração.

15 Médias do número de raízes desenvolvidas e suas respectivas massas de matéria fresca e seca, em gramas, observadas em estacas de primavera de $C$. rubra, tratadas com 5 tipos de recobrimento e armazenadas em condições de temperatura ambiente ou sob refrigeração.

16 Médias do número de rizomas desenvolvidos e suas respectivas massas de matéria fresca e seca, em gramas, em estacas de primavera de $C$. rubra, tratadas com 5 tipos de recobrimento e armazenadas em condições de temperatura ambiente ou sob refrigeração.

17 Médias do número de brotos desenvolvidos e suas respectivas massas de matéria fresca e seca, em gramas, observadas em estacas de primavera de C. rubra, tratadas com 5 tipos de recobrimento e armazenadas por 30,60, 90 ou 120 dias.

18 Médias do número de raízes desenvolvidas e suas respectivas massas de matéria fresca e seca, em gramas, observadas em estacas de primavera de $C$. rubra, tratadas com 5 tipos de recobrimento e armazenadas por 30,60,90 ou 120 dias. 
19 Médias do número de rizomas desenvolvidos e suas respectivas massas de matéria fresca e seca, em gramas, observadas em estacas de primavera de $C$. rubra, tratadas com 5 tipos de recobrimento e armazenadas por $30,60,90$ ou 120 dias.

20 Percentual do desenvolvimento de brotos, raízes e rizomas em estacas de outono de C. rubra, armazenadas por $30,60,90$ ou 120 dias, em condições de temperatura ambiente ou refrigerada $e$ submetidas aos diferentes tipos de recobrimento.

21 Médias dos números de brotos desenvolvidos em estacas de outono de C. rubra, armazenadas por 30, 60, 90 ou 120 dias, em condições de temperatura ambiente ou refrigerada e submetidas aos diferentes tipos de recobrimento

22 Médias das massas de matéria fresca de brotos, em gramas, desenvolvidos em estacas de outono de C. rubra, armazenadas por 30, 60, 90 ou 120 dias, em condições de temperatura ambiente ou refrigerada e submetidas aos diferentes tipos de recobrimento.

23 Médias das massas de matéria seca de brotos, em gramas, desenvolvidos em estacas de outono de C. rubra, armazenadas por 30, 60, 90 ou 120 dias, em condições de temperatura ambiente ou refrigerada e submetidas aos diferentes tipos de recobrimento.

24 Médias dos números de raízes desenvolvidas em estacas de outono de C. rubra, armazenadas por 30, 60, 90 ou 120 dias, em condições de temperatura ambiente ou refrigerada e submetidas aos diferentes tipos de recobrimento.

25 Médias das massas de matéria fresca de raízes, em gramas, desenvolvidas em estacas de outono de C. rubra, armazenadas por $30,60,90$ ou 120 dias, em condições de temperatura ambiente ou refrigerada e submetidas aos diferentes tipos de recobrimento. 
26 Médias das massas de matéria seca de raízes, em gramas, desenvolvidas em estacas de outono de $C$. rubra, armazenadas por 30, 60, 90 ou 120 dias, em condições de temperatura ambiente ou refrigerada e submetidas aos diferentes tipos de recobrimento.

27 Médias dos números de rizomas desenvolvidos em estacas de outono de C. rubra, armazenadas por 30, 60, 90 ou 120 dias, em condições de temperatura ambiente ou refrigerada e submetidas aos diferentes tipos de recobrimento

28 Médias das massas de matéria fresca de rizomas, em gramas, desenvolvidos em estacas de outono de C. rubra, armazenadas por 30, 60, 90 ou 120 dias, em condições de temperatura ambiente ou refrigerada e submetidas aos diferentes tipos de recobrimento.

29 Médias das massas de matéria seca de rizomas, em gramas, desenvolvidos em estacas de outono de $C$. rubra, armazenadas por 30, 60, 90 ou 120 dias, em condições de temperatura ambiente ou refrigerada e submetidas aos diferentes tipos de recobrimento.

30 Médias do número de brotos desenvolvidos e suas respectivas massas de matéria fresca e seca, em gramas, observadas em estacas de outono de C. rubra, armazenadas por $30,60,90$ ou 120 dias, em condições de temperatura ambiente ou sob refrigeração.

31 Médias do número de raízes desenvolvidas e suas respectivas massas de matéria fresca e seca, em gramas, observadas em estacas de outono de C. rubra, armazenadas por 30, 60, 90 ou 120 dias, em condições de temperatura ambiente ou sob refrigeração.

32 Médias do número de rizomas desenvolvidos e suas respectivas massas de matéria fresca e seca, em gramas, observadas em estacas de outono de C. rubra, armazenadas por 30, 60, 90 ou 120 dias, em condições de temperatura ambiente ou sob refrigeração. 
33 Médias do número de brotos desenvolvidos e suas respectivas massas de matéria fresca e seca, em gramas, observadas em estacas de outono de $C$. rubra, tratadas com 5 tipos de recobrimento e armazenadas em condições de temperatura ambiente ou sob refrigeração

34 Médias do número de raízes desenvolvidas e suas respectivas massas de matéria fresca e seca, em gramas, observadas em estacas de outono de $C$. rubra, tratadas com 5 tipos de recobrimento e armazenadas em condições de temperatura ambiente ou sob refrigeração.

35 Médias do número de rizomas desenvolvidos e suas respectivas massas de matéria fresca e seca, em gramas, observadas em estacas de outono de $C$. rubra, tratadas com 5 tipos de recobrimento e armazenadas em condições de temperatura ambiente ou sob refrigeração

36 Médias do número de brotos desenvolvidos e suas respectivas massas de matéria fresca e seca, em gramas, observadas em estacas de outono de C. rubra, tratadas com 5 tipos de recobrimento e armazenadas por $30,60,90$ ou 120 dias..

37 Médias do número de raízes desenvolvidas e suas respectivas massas de matéria fresca e seca, em gramas, observadas em estacas de outono de $C$. rubra, tratadas com 5 tipos de recobrimento e armazenadas por $30,60,90$ ou 120 dias

38 Médias do número de rizomas desenvolvidos e suas respectivas massas de matéria fresca e seca, em gramas, observadas em estacas de outono de $C$. rubra, tratadas com 5 tipos de recobrimento e armazenadas por 30,60, 90 ou 120 dias. 


\section{SAZONALIDADE, REFRIGERAÇÃO E DIFERENTES TIPOS DE RECOBRIMENTO NA CONSERVAÇÃO PÓS-COLHEITA DE ESTACAS DE CORDILINE (Cordyline rubra Hügel)}

Autor: NELSON MAMORU SAKAMOTO

Orientador: Prof. Dr. ROBERVAL DE CÁSSIA SALVADOR RIBEIRO

\section{RESUMO}

O mercado mundial de floricultura gera um fluxo de quase US\$7bilhões anuais, atualmente concentrado em países como Holanda, Alemanha, Itália, Colômbia, Costa Rica, Equador, Quênia, Tailândia, Malásia, Israel e EUA. O Brasil ainda contribui pouco, aproximadamente $0,3 \%$ do total, sendo a participação brasileira concentrada na exportação de mudas, bulbos, flores e folhagens tropicais. O Brasil possui grande potencial exportador de flores e plantas ornamentais através da organização dos produtores, profissionalização do setor, apoio governamental e desenvolvimento técnico. O emprego de técnicas simples de armazenamento poderia viabilizar o transporte por modais que não o aéreo, reduzindo custos e podendo prolongar a vida útil dos produtos, criando um diferencial de qualidade em relação aos concorrentes. Este trabalho compara cinco diferentes tipos de recobrimento em estacas de Cordyline rubra Hügel (película amilácea, pasta de parafina no ápice, pasta de parafina no ápice e vermiculita umedecida na base, saco plástico ou sem recobrimento), sazonalidade (estacas coletadas durante primavera ou outono), dois ambientes de armazenamento (ambiente refrigerado a $10^{\circ} \mathrm{C}$ ou temperatura ambiente $22-32^{\circ} \mathrm{C}$ ) e diferentes períodos de armazenamento (30, 60, 90 ou 120 dias), a fim de reduzir sua atividade biológica, perda de água e ataque de patógenos. Foi escolhida esta espécie por ser muito apreciada como planta ornamental devido à beleza de suas folhas, e exportada na forma de estacas de diferentes tamanhos. $O$ experimento foi conduzido nas dependências do Departamento de Produção Vegetal da Escola Superior de Agricultura "Luiz de Queiroz", Universidade de São Paulo, no município de Piracicaba, Estado de São Paulo. Foram utilizadas 615 estacas com $30 \mathrm{~cm}$ de comprimento por 
$3 \mathrm{~cm}$ de diâmetro. Um lote testemunha sem armazenamento de 15 estacas foi colocado em leito de enraizamento. Cada tratamento foi composto por 30 estacas pré-tratadas (tipos de recobrimento), submetidas a diferentes períodos de armazenamento (30, 60, 90 ou 120 dias), sendo divididos em 2 sub-tratamentos de 15 estacas (temperatura ambiente ou refrigerada), totalizando 120 estacas. Após o armazenamento foram cortados $3 \mathrm{~cm}$ da base de cada estaca, em seguida tratadas com IBA a $10.000 \mathrm{mg} / \mathrm{L}$ e colocadas em leito de enraizamento. Após 90 dias foram avaliados os seguintes parâmetros: porcentagem de desenvolvimento, número e massas de matéria fresca e seca de brotos, raízes e rizomas. Observou-se que as estacas colhidas na primavera apresentaram melhor enraizamento e produção de massas secas e frescas. Os menores períodos de armazenamento proporcionam melhor desenvolvimento das estacas, bem como estacas armazenadas em ambiente refrigerado apresentaram melhores resultados do que as mantidas em temperatura ambiente. Os tipos de recobrimento que melhor conservaram as estacas, em ordem decrescente de resultados, foram o saco plástico, parafina no ápice e vermiculita umedecida na base, parafina no ápice, película de amido e sem recobrimento. Conclui-se que o método mais prático foi embalar as estacas em sacos plásticos por não necessitar de fonte de calor para o preparo da película. Quanto maiores os períodos de armazenamento, menores desenvolvimentos de brotos, raízes e rizomas; os melhores resultados foram obtidos com estacas colhidas na primavera e armazenadas em ambiente refrigerado. 


\title{
SEASONALITY, REFRIGERATION AND DIFFERENT TYPES OF COATING ON THE POSTHARVEST CONSERVATION OF Cordyline rubra Hügel CUTTINGS
}

\author{
Author: NELSON MAMORU SAKAMOTO \\ Adviser: Prof. Dr. ROBERVAL DE CÁSSIA SALVADOR RIBEIRO
}

\section{SUMMARY}

The world market of floriculture, generates an annual flow of US\$ 7billion, is currently based on countries like The Netherlands, Germany, Italy, Colombia, Costa Rica, Ecuador, Kenya, Thayland, Malaysia, Israel and the USA. The Brazilian contribution to the total world market is approximately $0.3 \%$, where the mains exports are cuttings, bulbs, tropical fresh cut flowers and foliages. Brazil, however, has a great potential to increase its export of flowers and other ornamental plants through the better organization of producers, professionalization of the sector, government support and technical development. The use of simple storage techniques, would enable the transport through other means than airplanes, consequently reducing costs and adding extra shelf life to the product, creating a quality differentiation in relation to competitors. This work was aimed at comparing five types of coating of Cordyline rubra Hügel cuttings (starch film, paraffin paste at the apex, paraffin past at the apex associated with moist vermiculite at the base of the cuttings, plastic bags or no coating), seasonality (cuttings harvested during spring or autumn), two types of enviromental temperatures (refrigeration under $10^{\circ} \mathrm{C}$ or environmental temperature between $22-32^{\circ} \mathrm{C}$ ) and different lengths of time on storage (30, 60, 90 or 120 days), in order to reduce their biologycal activity, water loss and pathogen attacks. This specie is very appreciated as an ornamental plant due to the beauty of their foliage and is exported as cuttings of different sizes. The experiment was carried out at the Departament of Plant Production at "Luiz de Queiroz" College of Agriculture, University of Sao Paulo, in Piracicaba City, Sao Paulo State, Brazil. A total of 615 cuttings were used, each measuring $30 \mathrm{~cm}$ by $3 \mathrm{~cm}$ diameter. A control group of 15 cuttings without storage was 
planted on rooting bed. Each treatment was comprised of 30 pre-coated cuttings (types of coating), stored at different periods (30.60, 90 or 120 days) and split into 2 sub-treatments of 15 cuttings, either stored at room temperature or under refrigeration, summing up 120 cuttings. After storage, each cutting had $3 \mathrm{~cm}$ excised from its base, prior to being treated with IBA $10.000 \mathrm{mg} / \mathrm{L}$ and placed at rooting beds. After 90 days, the following parameters were assessed: percentage of cuttings showing growth and development, number and fresh and dry matter of the shoots, roots and rhizoms. It was observed that cuttings obtained during the spring, showed better rooting and production of biomass. The shorter the storage periods the better the cutting sprouting. Cuttings stored under refrigeration showed better results than kept under room temperature. The types of coatings which best supported the longevity of the cuttings, in decrease order, were: plastic bag, paraffin paste at the apex and moist vermiculite at the base, paraffin on the apex, starch film and no coating. Such results allow to conclude that the most practical coating technique was found to be the use of plastic bags, which did not need heating for the prepare of the film. The longer the storage time the smallest the number of viable cuttings; best results where observed for cuttings harvested during the spring and kept under refrigeration storage. 


\section{INTRODUÇÃo}

A floricultura pode ser definida como a exploração de plantas para finalidades ornamentais e estéticas. Neste conceito estão inseridas, a cultura de flores e folhagens de corte (para uso em vasos ou arranjos florais), mudas de espécies arbóreas, arbustivas e herbáceas, plantas envasadas, além daquelas destinadas à cobertura do solo, como os gramados e forrações.

O mercado mundial de flores e plantas ornamentais gera um fluxo no comércio internacional da ordem de 6,7 bilhões de dólares anualmente, hoje concentrado em países como Holanda, Colômbia, Itália, Dinamarca, Bélgica, Quênia, Zimbábue, Costa Rica, Equador, Austrália, Malásia, Tailândia, Israel e EUA. A participação nacional é de apenas 0,3\% no fluxo internacional dessas mercadorias (Junqueira \& Peetz, 2002).

A participação brasileira é concentrada principalmente na exportação de mudas de flores e plantas ornamentais $(55 \%)$, bulbos $(26 \%)$, além de rosas, flores tropicais como orquídeas, bromélias, abacaxis ornamentais, zengiberáceas e outros ítens. As folhagens brasileiras também têm muito boa e crescente aceitação no mercado internacional (Junqueira \& Peetz, 2002). As folhagens contribuem com $10 \%$, os bulbos com $9 \%$, outras flores com $5 \%$, orquídeas com 3\% e dracenas e cordilines com 1\% (Almeida \& Aki, 1995; Matsunaga, 1995).

Segundo Walt (2001 citado por Anefalos, 2004), a concorrência internacional está se acirrando, pois as empresas holandesas estão buscando melhorar a sua produtividade com o uso de tecnologias mais avançadas e a instalação de plantações em regiões mais propícias ao cultivo de flores, como é o caso do continente africano (Zimbábue e Quênia) e de Israel.

De acordo com Perosa (2002), para o período de 1992 a 2000, as exportações para os Países Baixos (principalmente bulbos) representaram mais da metade do total exportado. A exportação para esse país bem como para a Itália (principalmente mudas de crisântemo) e Alemanha (sobretudo rosas) são responsáveis por cerca de $10,03 \%$ do total. Os EUA participam com $5,10 \%$ das importações, valor próximo do verificado para a Argentina, $4,40 \%$.

Devido às barreiras de ordem fitossanitárias impostas pela maioria dos países quanto à importação de material vegetal contendo solo, ele é normalmente exportado na forma de flores 
cortadas (rosas), bulbos (gladíolo), mudas com raiz nua (violeta), cultura in vitro (orquídeas) ou ainda na forma de estacas (dracenas). Apesar da maioria das estacas comercializadas ser destinada à produtores de plantas envasadas, grande parte dos varejistas que operam no Mercado Flutuante de Flores em Amsterdã - Holanda, comercializam estacas de Dracaena spp. (dracenas - as mais comercializadas), Bougainvillea spp. (primaveras), Polyscias spp. (árvores da felicidade) e filhotes de Beaucarnea spp. (pata de elefante) e Cycas spp. (palmeira cicas) parcialmente recobertos por parafina. O preço é bem menor quando comparado com plantas envasadas já formadas.
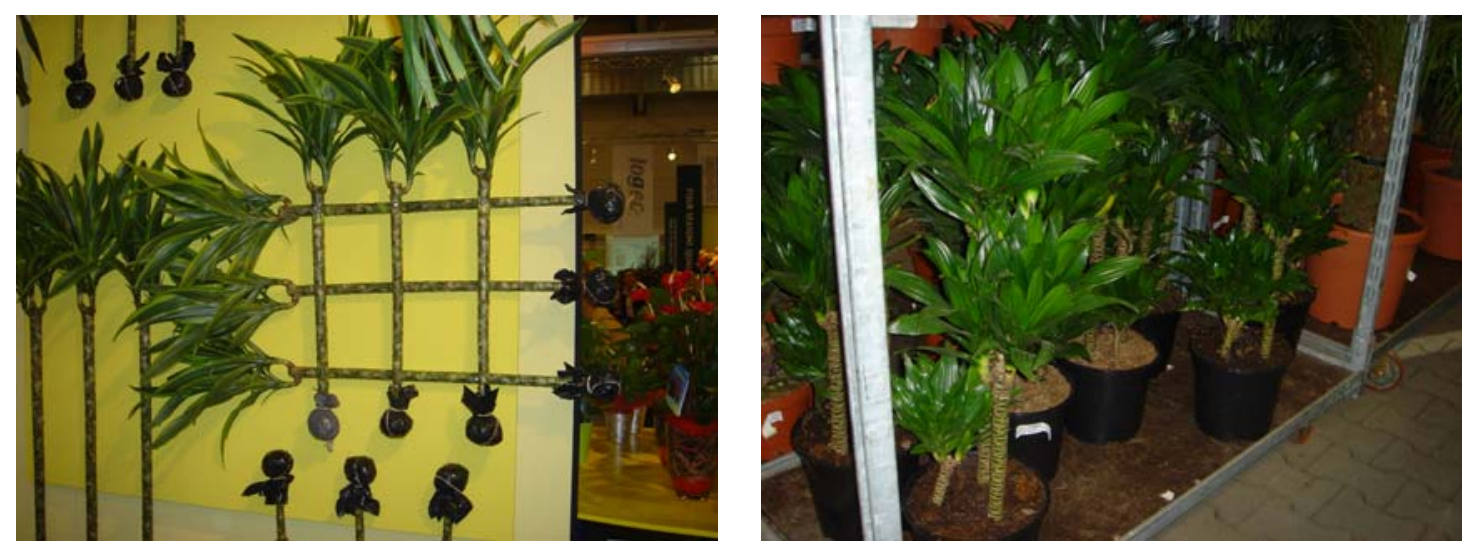

Figura 1 - Exposição de mudas (esq.) e de plantas envasadas (dir.) de dracenas e cordilines na IPM (Internationale Pfanzenmesse) - Essen/Alemanha (Arquivo pessoal, 2005)

A empresa Plantas Exóticas do Brasil Agri Floricultura Ltda, localizada em Juquiá - SP, uma das regiões mais carentes do Estado de São Paulo, vem explorando este mercado. É deles a afirmação que apesar do recente aumento das exportações da empresa para o Mercosul, o Brasil tem sofrido grande concorrência de países como Costa Rica e Guatemala nos mercados norte americano e europeu.

A produção de estacas de plantas ornamentais também constitui-se numa boa alternativa para os produtores de regiões distantes dos grandes centros consumidores no Brasil.

Nestes últimos anos, outros países produtores emergentes, têm se especializado na produção de folhagens tropicais, como Sri Lanka, Tailândia, Malásia e também alguns países do continente africano, Quênia e Zimbábue.

No transporte internacional de flores de corte predominam aviões e caminhões e, por se tratar de um produto perecível, há diversos riscos envolvidos. Se houver qualquer atraso no transporte, podem ocorrer perdas para o exportador, que dificultam ainda mais a entrada do produto em países estrangeiros (Anefalos, 2004). 
O emprego de técnicas simples de armazenamento, dentro da realidade do produtor, poderia viabilizar o transporte via fluvial e marítimo, que apesar de mais barato, exige períodos de armazenamento razoavelmente longos. Além disso, tais técnicas poderiam prolongar a vida de prateleira dessas estacas junto ao mercado varejista, criando um diferencial de qualidade do produto brasileiro em relação aos concorrentes.

Este trabalho tem como objetivo comparar diversos tipos de recobrimento em estacas de Cordyline rubra Hügel, visando reduzir a sua atividade biológica. Espera-se minimizar a perda d'água e ataques de patógenos, estendendo dessa forma o período de armazenamento dessas estacas sob duas condições ambientais: temperatura ambiente e em ambiente refrigerado. Este trabalho também visa verificar o efeito da sazonalidade sobre a longevidade e capacidade de enraizamento dessas estacas após 30, 60, 90 ou 120 dias de armazenamento.

Acima de tudo, este trabalho pretende ser uma contribuição ao esforço da floricultura brasileira em conseguir maior participação no importante mercado internacional. 


\section{REVISÃO DE LITERATURA}

\section{1 Panorama internacional da floricultura}

O mercado mundial de flores e plantas ornamentais gera um fluxo no comércio internacional da ordem de 6,7 bilhões de dólares anualmente, hoje concentrado em países como Holanda, Colômbia, Itália, Dinamarca, Bélgica, Quênia, Zimbábue, Costa Rica, Equador, Austrália, Malásia, Tailândia, Israel, EUA (Hawai) e outros (Junqueira \& Peetz, 2002).

Além da tímida participação do Brasil no mercado mundial, o consumo de plantas ornamentais ainda é baixo no próprio país. Em estudo relativamente recente, o mercado de floricultura foi estimado em US\$3,00-4,00/habitante/ano no Brasil, enquanto na Argentina esse valor subia para US $\$ 25,00$, na Europa Continental oscilava de US\$ 60,00 a US $\$ 90,00$, nos países escandinavos chegava a US\$120,00, culminando com o Japão, onde a cifra de US $\$ 180,00$ se igualava a de consumo de frutas (Almeida \& Aki, 1995). Nos dias de hoje, estima-se que o consumo per capita no Brasil seja em torno de US $\$ 6,00$ (Fernandes, citado por Zafalon, 2003). O Brasil necessita, portanto concentrar esforços em duas estratégias: estimular o consumo interno e a exportação.

Dois países servem como ponto de referência para o Brasil em relação à floricultura. Os Estados Unidos pela perspectiva de marketing e consumo e a Holanda por ser o centro de desenvolvimento em tecnologia de produção e pesquisas de novas espécies e variedades, posteriormente adaptadas para o resto do mundo.

\section{1. 1 Estados Unidos}

Os EUA têm uma produção equilibrada (entre flores de corte, em vaso e folhagens). As principais regiões de produção norte-americana localizam-se na Flórida, Califórnia e Havaí, que competem com os produtos brasileiros devido ao clima tropical ou subtropical. A produção de flores cortadas nos EUA é altamente massificada com pequena diversificação na variedade. As 
vendas de maneira geral estão estáveis, as indústrias têm ganho, principalmente devido à produção de plantas de jardins, que continua em ascensão, porém trata-se de um segmento praticamente esgotado (Laws, 1997; Matsunaga, 1995).

A produção de flores de corte caiu 23\% de 1990 a 1995 (mais da metade das flores de corte consumidas são importadas, em sua grande maioria da Colômbia). Flores de vaso caíram $6 \%$; folhagens e plantas verdes caíram $8 \%$. Em contraste, plantas para jardim cresceram mais de $41 \%$. No entanto, já se faz notar uma diminuição na produção de plantas para jardins, pois o mercado consumidor já está se estabilizando (Laws, 1997; Matsunaga, 1995).

Atualmente, os EUA têm exportado para o Brasil grande quantidade de material na forma de sementes e material de propagação de plantas ornamentais, já que "joint ventures" tem se formado entre empresas brasileiras e americanas.

\section{1. 2 Holanda}

A indústria holandesa tem sido prejudicada pelo alto valor de sua moeda, pela concorrência do Sul e do Leste Europeu (onde a produção está progredindo rapidamente), pelo alto custo para implementação de requerimentos da legislação ambiental holandesa. Enquanto o volume total de vendas (em dinheiro) dos leilões manteve-se estável as quantidades aumentaram. Tal aumento demanda mais pressão no preço unitário causando um declínio do lucro. O preço das flores de corte caiu 1,6\% e o das plantas de vaso 1,3\%. As plantas de jardim tiveram um acréscimo de $13 \%$ no valor da venda (Almeida \& Aki, 1995; Hamrick, 1996; Matsunaga, 1995).

A Holanda perdeu nestes últimos anos um importante mercado, o da Alemanha, que era um grande comprador de flores e plantas ornamentais da Holanda e que agora elaborou uma estrutura de importação e distribuição nos moldes holandeses.

\section{1.3 Japão}

O Japão tem preferência pela flor cortada por influência da tradição do "ikebana" (arranjos florais). A produção de flores e plantas ornamentais totalizou, em 1992, cerca de US\$ 4,6 bilhões, com uma tendência de crescimento da demanda à taxa de 5 a $6 \%$ ao ano, o que levou aquele país a investir nos países próximos do sudeste da Ásia, notadamente Tailândia e Taiwan. O mercado interno japonês é tão grande que a oferta interna não atende à demanda, apesar da crescente participação da Austrália e Nova Zelândia naquele mercado. A produção 
de flores de corte representa mais de $40 \%$ do mercado de flores e plantas ornamentais, com destaque para crisântemo, rosa e cravo (Hamrick, 1996; Matsunaga, 1995). Isto torna o Japão o principal mercado de plantas ornamentais e flores do sudeste da Ásia.

Muitas empresas japonesas têm aproveitado o baixo custo da mão de obra de outros países asiáticos e terceirizado o serviço de produção das plantas. As empresas japonesas fornecem mudas e/ou matrizes de seu interesse e recebem de volta as plantas quando adultas.

\section{1. 4 Países latino-americanos}

A Colômbia é o segundo maior exportador mundial de flores cortadas, com grande penetração no mercado americano. É um país privilegiado por sua localização, clima e altitude. Situa-se acima da linha equatoriana, onde há pouca variação das horas durante o dia, portanto o ciclo de produção é maior do que o nosso. Sua floricultura foi desenvolvida, em grande parte estimulada pelo governo americano, como uma cultura alternativa à plantação de coca (Bongers, 1995; Laws, 1997).

Segundo Matsunaga (1995), a produção de flores do Equador está concentrada próxima a Quito, no platô dos Andes, onde os dias são quentes e as noites frescas. Com uma indústria de floricultura que começou em 1983 o Equador já é o segundo exportador para os EUA, tomando o lugar do México. Em 1993 foram exportadas US\$ 40 milhões em flores entre rosa, gipsofila, flor do campo (estatice, lisianto). O Equador se tornou um país exportador de flores graças ao programa de governo destinado a promover a exportação de produtos não tradicionais como flores, frutas e vegetais. O Equador também está crescendo em importância e se tornou o novo padrão de qualidade para rosas de hastes longas. O mercado interno é praticamente desprezível.

Além do Brasil, o México, a Costa Rica, a Guatemala e a Argentina são os países com a indústria de flores em constante crescimento. Os produtores de folhagens e plantas verdes da Costa Rica e Guatemala suprem uma significativa fatia de mercado de folhagens na Flórida, Estados Unidos e também em algumas partes da Europa, concorrendo diretamente com os exportadores brasileiros (Matsunaga, 1995).

\section{1. 5 Países asiáticos}

Além da Tailândia e Taiwan os demais países que buscam na floricultura uma nova fonte alternativa econômica são Indonésia, Cingapura, Filipinas e Sri - Lanka. Enfrentam, porém 
problemas semelhantes aos produtores brasileiros. Ou seja, produção em pequena escala, baixo valor unitário da flor, comércio de mercado interno, qualidade ainda aquém do desejável para exportação, mão-de-obra não qualificada e escassez de capital (Matsunaga, 1995). A vantagem desses países em relação ao Brasil é representada pela distância do Japão, traduzida em menores custos com frete. Deste modo, as melhores opções para o Brasil, são os mercados dos EUA e da Europa, embora tenha que enfrentar concorrentes competitivos como Colômbia, Equador, México, Costa Rica, cujas distâncias para os mercados americano e europeu são bem menores.

Atualmente, esses países são grandes produtores de orquídeas e folhagens tropicais e também visam os mercados americano, japonês e europeu, tendo como vantagem o seu baixo custo com mão de obra.

\section{2 Panorama nacional da floricultura}

\section{2. 1 Situação atual}

A floricultura no Brasil não é uma atividade nova, porém incrementou suas atividades a partir da década de 30 , quando imigrantes japoneses se estabeleceram na região de São Paulo, mas as maiores empresas surgiram a partir da década de 60 quando imigrantes holandeses trouxeram novas técnicas de produção. Como atividade econômica, passou a ter importância a pouco mais de 20 anos, apresentando uma taxa anual de crescimento por volta de $20 \%$ (Arruda, 1996).

O mercado interno de flores e plantas ornamentais experimentou um fantástico crescimento na década de 90 (média de $25 \%$ ao ano). De acordo com estimativas, o setor movimenta cerca de US\$600 milhões por ano no País como um todo, com o Estado de São Paulo representando cerca de $70 \%$ da produção nacional (Almeida \& Aki, 1995).

O comportamento das exportações brasileiras de plantas vivas e produtos de floricultura oscilou no período de 1992 a 2000, tanto em valores como em quantidade. A taxa de crescimento do total exportado foi de $3,9 \%$ ao ano. Já as importações revelaram um comportamento crescente de $21 \%$ ao ano (Perosa, 2002).

Segundo Perosa (2002), no ano 2000, as exportações de produtos agropecuários representaram 7,6 bilhões de dólares, sendo que o setor de plantas ornamentais figurou com 11,9 milhões de dólares, apenas. Junqueira \& Peetz (2002), revelaram que o país elevou as exportações em cerca de $26 \%$ em 2002, passando a 14,9 milhões de dólares. 
Atualmente, os mercados prioritários para as exportações do Brasil são: Alemanha, Holanda, EUA, Itália, França, Inglaterra, Japão e Argentina. Também é evidente o crescente interesse dos mercados dos países ibéricos (Portugal e Espanha) pelos produtos brasileiros, notadamente para flores e folhagens tropicais. E como mercados opcionais, em fase de prospecção, encontram-se Rússia e Emirados Árabes (Junqueira \& Peetz, 2002).

No Estado de São Paulo o setor de flores e plantas ornamentais congrega cerca de 2.500 produtores abrangendo cerca de 10.000 hectares de produção de diferentes tipos de flores de corte, tais como crisântemo, rosa, gipsofila e mistura de flores; flores em vaso, como a violeta africana, crisântemo e azaléia; folhagens ornamentais em vaso; orquídeas; forragens; grama; mudas em geral e bulbos. Numa estimativa bastante modesta de cinco trabalhadores por propriedade, haveria cerca de 50.000 empregos no setor, dedicados exclusivamente a essa atividade (Matsunaga, 1995).

Os pequenos e grandes produtores coexistem numa produção bastante diversificada, sendo que os maiores, mais especializados, atingem escala de produção compatível com a tecnologia americana, como podem ser observadas nas culturas de violeta africana, crisântemo, rosa, lírio-da-paz, samambaia e orquídea (Matsunaga, 1995).

Atualmente, as fronteiras de produção de flores e plantas ornamentais estão avançando para outras regiões, em busca de climas mais favoráveis e proporcionando produtos de melhor qualidade a um preço competitivo (Groot, 2003). Pode se destacar principalmente o Estado do Ceará, com o incentivo de seu governo aos produtores, mais precisamente na região da Serra do Ibiapaba, devido a seus fatores climáticos.

A tecnologia de produção não é homogênea, sendo melhor aproveitada pelos grandes produtores. $\mathrm{O}$ uso de estufas começa a se disseminar entre os produtores associados com o uso da irrigação controlada, nebulização e fertirrigação. Tecnologias mais sofisticadas, que associam o uso da informática no controle das condições internas da estufa, já estão disponíveis no mercado. Consegue-se assim superar a sazonalidade, também, criando uma demanda permanente de mercado. Antes, o mercado de flores era caracterizado por um comércio bastante forte, principalmente no dia das mães, em finados e no Natal. Hoje têm se oito ou mais datas fortes durante 0 ano. Pretende-se atingir uma expansão ainda maior entrando na linha de supermercados, onde se cria uma demanda quase constante durante 0 ano. Quebra-se a sazonalidade e o produtor passa a investir mais na continuidade (Bongers, 1995; Matsunaga, 1995).

No Brasil as flores são vendidas mais para presentes, portanto o mercado estruturou-se sobre as floriculturas. Considerando-se ainda que pelo menos metade do mercado é constituída por pontos-de-venda tradicionais, a situação do preço para o consumidor e a marca do produtor 
foram sensivelmente prejudicadas. Em termos de agribusiness, talvez esteja aí a maior dificuldade para o setor (Bongers, 1995; Matsunaga, 1995).

A tendência é que as flores deixarão de ser o presente principal de consumidores e passarão a ser utilizados como complementos, acompanhando outros presentes (Aki, $2003^{1}$ ).

No Estado de São Paulo, o setor de floricultura começa a se estruturar em moldes empresariais. A Câmara Setorial de Flores e Plantas Ornamentais consegue reunir todos os segmentos, da produção à comercialização, integrando as preocupações com os setores de serviços e insumos. Compõem esta Câmara os Institutos de Pesquisa das Secretarias de Agricultura e Abastecimento e do Meio Ambiente, Universidades, Serviço de Extensão e o Setor Financeiro. Além da Câmara, existem entidades em defesa do setor representadas pelo Instituto Brasileiro de Floricultura (IBRAFLOR), Associação Brasileira de Floricultura (ABRAFLOR), Sociedade Brasileira de Floricultura e Plantas Ornamentais (SBFPO), Sociedade Brasileira de Arborização Urbana (SBAU), entre outros.

A estrutura de comercialização, representada pela Companhia de Entrepostos e Armazéns Gerais de São Paulo (CEAGESP), Centrais de Abastecimento S/A de Campinas (CEASA-Campinas), leilão do Veiling Holambra e o atacado de plantas ornamentais da Associação Central de Produtores de Flores e Plantas Ornamentais, garante especialmente o suporte da distribuição do atacado das flores e plantas ornamentais no Estado. A produção estrutura-se em moldes cooperativos como a Holambra e associativos como a Central que congrega cinco associações regionais, além de diversas associações isoladas (Almeida \& Aki, 1995).

\section{2. 2 Perspectivas para o futuro}

A floricultura no Brasil deve ser encarada como uma atividade de grande importância econômica e social, capaz de promover o desenvolvimento tecnológico na agricultura e contribuir para melhorar o nível social de uma determinada região.

Contribuindo ao nível orçamentário, as flores e plantas ornamentais brasileiras apresentam excelentes oportunidades a serem exploradas no mercado de exportação. Segundo Olivetti et al. (1994), várias são as causas que favorecem esta atividade: tradição do povo americano e europeu em adquirir flores e plantas; baixo custo de produção, em nosso país, comparado ao custo de casas-de-vegetação e mão-de-obra dos países do hemisfério norte; potencialidade de nossas espécies nativas, ainda mal exploradas; possibilidade de oferta durante todo o ano.

\footnotetext{
${ }^{1}$ AKI, A. Comunicação pessoal, 2003.
} 
$O$ advento do MERCOSUL traz perspectivas ainda melhores para o crescimento das exportações, especialmente para espécies complementares às encontradas em outros países membros e associados. A possibilidade de utilização das Hidrovias Tietê-Paraná e ParanáParaguai também abre novo horizonte na pauta de exportações e uma nova alternativa econômica para o Oeste Paulista.

Entretanto, a qualidade e a uniformidade dos nossos produtos, aliadas ao deficiente sistema de produção, armazenamento, distribuição e comercialização, devem ser encarados de maneira mais séria, a fim de proporcionar a expansão desta área tão promissora. A competição não está acirrada apenas no mercado internacional. O mercado interno brasileiro necessita de maior atenção por parte do setor público e privado, na criação de uma estrutura de produção de nível internacional para enfrentar a concorrência dos importados.

De acordo com Perosa (2002), embora crescentes, as exportações não apontam um aumento da participação relativa do Brasil, uma vez que se observa um aumento ainda maior das importações. Essa evolução é indicativa de uma perda de competitividade dos produtos de floricultura, mostrando a necessidade de ações de médio e de longo prazo para um crescimento ainda maior das exportações. Atentando-se para os três últimos anos, verifica-se um crescimento mais pronunciado da quantidade e do valor exportado, indicativo de ações coordenadas de instituições promotoras de exportação, casos do IBRAFLOR e da APEX.

Com relação à exportação também há o problema tributário, a falta de infra-estrutura portuária, padronização e os problemas fitossanitários (Bongers, 1995). Além disso, até recentemente o Brasil não reconhecia o direito de patentes sobre variedades. Como resultado, empresas e geneticistas que trabalhavam com melhoramento não investiam na multiplicação desses materiais no país, restando ao Brasil variedades já ultrapassadas no mercado internacional. Isto, porém está mudando desde que a lei no. 9456 de Proteção de Cultivares foi aprovada em 25/04/1997.

O Brasil, por sua extensão geográfica, apresenta uma amplitude muito grande de clima e solo, favorecendo a implantação de uma floricultura diversificada e rica, além de possuir uma flora natural extremamente variada e pouco explorada comercialmente. A introdução de espécies mais resistentes às condições tropicais, o aprimoramento das técnicas de cultivo de espécies convencionais e a adequação cultural de outras podem levar o Brasil a um lugar de destaque no cenário mundial de Floricultura (Bongers, 1995).

Para a floricultura brasileira ter participação mais ativa tanto no cenário interno como no cenário externo, deverá ser dada importância a programas de capacitação ao segmento, transformando produtores rurais em empresários rurais, oferecendo produtos de acordo com as exigências dos mercados consumidores a preços competitivos. 
Um bom indicador, que serve como referência para o setor de floricultura, são os eventos especializados realizados para atender profissionais deste setor. Principalmente feiras como Hortitec, Garden Fair, Hort Flor, Fiaflora entre outros, que vem crescendo a cada ano.

\section{3 Características do gênero Cordyline}

Cordyline é um gênero de espécies arbustivas de porte grande, originárias da Índia, Malásia e Polinésia, de 1,0 - 2,5 m de altura, com folhas coriáceas e espessas. Possuem inflorescências longas, terminais com flores não vistosas e pouco significativas. Multiplica-se geralmente por estacas e sementes (Lorenzi \& Souza, 1999).

Foi selecionada a espécie Cordyline rubra Hügel, pela boa aceitação mundial, pela facilidade e rusticidade e cultivo e pela versatilidade das condições de uso. Pode ser utilizada tanto em jardins, como vasos e cultivada em solo, ou mantidas por longos períodos em recipientes com água (hidrocultura). Também são encontradas crescendo a pleno sol ou a meia sombra. Por isso freqüentemente são empregadas como plantas de interior, porém quando cultivadas em pleno sol podem, ser plantadas isoladamente, em conjuntos ou ainda em renques, sendo bastante úteis para cercas vivas. Além disso, suas folhagens podem ser empregadas em arranjos florais.

Pode se dizer ainda que $C$. rubra possui formas recurvadas, folhas vermelhoacobreadas. Formam arbustos delgados, intermediários, entre C. terminalis e C. stricta. Podem crescer até cerca de 5 metros; folhagem continua, ascendente, inseridas próximas umas das outras, oblanceoladas e espessas, normalmente verde escuras, embora possam ser avermelhadas quando novas (Graf, 1986).

Também apresentam fácil multiplicação por estacas e crescimento relativamente rápido. Possuem a peculiaridade de poderem ser propagadas por macroestacas, ou seja, hastes inteiras da planta podem ser retiradas e enraizadas com sucesso, sendo posteriormente transplantada para vaso ou jardim, adicionando volume imediato a este.

Segmentos de caule colocados em recipiente com água brotam e enraízam, motivo pelo qual são popularmente conhecidos por "pau-d'água". São atualmente cultivadas para comercialização tanto na forma de mudas como de estacas (em especial para exportação) e folhagem. Esta por ser muito decorativa é utilizada como pano de fundo em arranjos florais, especialmente os tropicais.

A fórmula mais recomendada para a adubação é a NPK 3-1-2 mais micronutrientes, cerca de $100 \mathrm{~g}$ de $\mathrm{N}$ por 1000 plantas em aplicações mensais, cultivos sujeitos a chuvas pesadas ou irrigações freqüentes, necessitam de adubações mais pesadas. $\mathrm{O} \mathrm{pH}$ do substrato 
deve estar entre $5,5-6,0$, observando se os níveis de fluoretos, que podem ser tóxicos à planta. A exigência em relação a umidade estão na ordem de 60 a $70 \%$. Os principais tratos culturais são irrigação, podas, pulverizações, adubações e capinas (Lamas, 2001).

\section{4 Armazenamento de produtos perecíveis usando ceras, parafinas, filmes plásticos e películas de fécula de mandioca}

O armazenamento tem por objetivo minimizar a intensidade do processo vital dos produtos perecíveis, através de modificações das condições ambientais naturais, permitindo uma redução no metabolismo normal, sem alterações fisiológicas. Assim sendo, evitam-se a brotação, elongação, germinação de sementes, ataque de patógenos, injúrias fisiológicas e desidratação.

O grau de perecibilidade depende de fatores intrínsecos ligados a espécie, tais como genótipo, taxa respiratória e produção de etileno e de fatores externos como temperatura, umidade e fitossanidade.

Entre os processos de armazenamento de estacas existem os naturais (mantê-las em pé com a porção proximal em água e num local fresco e abrigado do vento e luz, por exemplo), que são geralmente de curto prazo ou os processos tecnológicos mais avançados, que promovem um tempo maior de armazenamento, como a refrigeração, o controle atmosférico ou o uso de produtos químicos para evitar desidratação e ataque de patógenos. $O$ uso de ceras e parafinas, com ou sem fungicidas, vai de encontro a essa finalidade e constitui-se numa opção relativamente barata. Outra opção de baixo custo é o uso de filmes plásticos.

Embora várias publicações já existam no Brasil e exterior a respeito do uso de ceras para preservação das qualidades e prolongamento do armazenamento de frutos e hortaliças, a literatura a esse respeito em estacas de plantas ornamentais é muito escassa.

Ceras ou emulsões de ceras quando usadas como cobertura superficial em certos produtos perecíveis, reduzem a perda de umidade e retardam o enrugamento, bem como podem conferir ao produto maior brilho superficial, o que em muitos casos é apreciado pelo consumidor (Chitarra \& Chitarra, 1990). As ceras disponíveis no comércio são normalmente formulações contendo misturas de ceras derivadas de petróleo ou de vegetais. Algumas delas contém parafina em sua composição, pela boa proteção que oferecem contra a perda d'água. $A$ parafina porém não confere o brilho adequado que outras formulações, por exemplo, contendo cera de carnaúba oferecem (Chitarra \& Chitarra, 1990). A espessura dessa cobertura é crítica, pois se muito fina não apresenta efeito contra a perda de umidade. Do contrário, se muito espessa, pode favorecer o aparecimento de doenças e o colapso interno do produto devido à 
anaerobiose como no caso de melões honeydew (Cucumis melo var. inodorus) (Edwards \& Blennerhassett, 1990).

O emprego de ceras para minimizar a perda d'água, algumas vezes é associado com aumento do ataque de fungos. Por esta razão, fungicidas são outros produtos freqüentemente adicionados às ceras para retardar deteriorações, como por exemplo, benomyl e thiabendazole em abacate (Darvas et al., 1990). No caso de maçã cv. Golden Delicious a combinação do fungicida captafol com o uso de cera aumenta a vida de prateleira em até 100\% (Gupta \& Gupta, 1992). Em laranja cv. Agepe 1 e pomelo cv. Ruby Red o uso de cera em combinação com banho de fungicida minimizou a perda de peso, melhorou a aparência e prolongou, sem prejudicar, as qualidades comerciais (Aworh et al., 1991).

Muitas vezes a combinação de diversos produtos leva a um melhor resultado. Num trabalho com laranja cv. Mosambi, Tarkase \& Desai (1989) observaram que os melhores resultados em termos de vida de prateleira foram atingidos com a combinação de cera contendo 2,4-D e o fungicida carbendazim. Além disso os frutos acondicionados em sacos plásticos não perfurados duraram mais que em sacos perfurados. A combinação das três variáveis deu melhores resultados do que usadas isoladamente.

Técnicas acessórias na desinfestação do material a ser tratado com parafina, como por exemplo o uso de solução de hipoclorito de sódio em melão (Edwards \& Blennerhassett, 1990) e tangelos (Chun et al., 1990) também são indicados como coadjuvantes no prolongamento do período de armazenamento. As ceras podem também conter preservativos químicos como emulsificantes, umectantes, polietileno, resinas sintéticas, etc. (Chitarra \& Chitarra, 1990).

A partir dos estudos acima citados é de se esperar que estacas tenham benefícios similares. Souza (1990) trabalhando com estacas de seringueira (Hevea brasiliensis), concluiu que a parafinagem foi o melhor e mais prático método de armazenamento de hastes de seringueira para enxertia até 8 dias. $O$ aumento no tempo de armazenamento provocou um decréscimo no sucesso da enxertia e o índice de pegamento tornou-se nulo aos 16 dias para hastes armazenadas em meio ambiente, câmara fria, extremidades parafinadas e serragem curtida úmida.

Dentre as poucas citações do uso de ceras em plantas ornamentais destacam-se o uso de cera misturada a cimento Portland aplicados na porção distal de estacas de Dracaena fragrans cv. Massangeana para evitar perda d'água; os primeiros $2,5 \mathrm{~cm}$ da porção proximal destas estacas foram submergidas por aproximadamente 2 segundos em solução de AIB (10.000 ppm) dissolvido em álcool (Poole \& Conover, 1992); estes autores armazenaram as estacas no escuro a $21^{\circ} \mathrm{C}$ por até 8 semanas, quando foram transferidas para substrato de madeira triturada e irrigados com nebulizadores até a emergência de raízes e brotos caulinares. Também observaram que a posição das estacas é muito importante: estacas de $30 \mathrm{~cm}$ de 
comprimento armazenadas na posição horizontal apresentaram maior enraizamento e crescimento de brotos caulinares (proporcional ao tempo de armazenamento) quando comparadas com aquelas armazenadas na posição vertical. Estacas de $60 \mathrm{~cm}$ apresentaram o mesmo comportamento exceto pelo número de raízes brotadas, que diminuiu com o tempo de armazenamento.

Não foi encontrado na literatura relato de danos causados pela temperatura usada na aplicação da emulsão de parafina. Pelo contrário, o tratamento térmico de estacas de vários exemplares altamente ornamentais (Plumeria hybrid cv. Donald Augus, Dracaena fragans cv. Massangeana, D. deremensis cvs. Warneckii e Janet Craig, D. marginata e Gardenia jasminoides) submergidas em água quente $\left(49^{\circ} \mathrm{C}\right.$ por 10 minutos $)$ seguidos por uma aplicação basal de $0.8 \%$ AIB mostraram um percentual de enraizamento (76.7\%) e número de raízes por estaca (9.7) significativamente maiores quando comparados aos valores correspondentes observados nos tratamentos que receberam somente AIB (53.3\% e 6.2), tratamento térmico (40.0\% e 2.0) e material não tratado (controle; $33.3 \%$ e 1.5) (Hata et al., 1994).

O uso de filmes plásticos como embalagem tem a vantagem de retardar a senescência e reduzir a perda de peso, aumentando a vida de prateleira e desperdício do produto perecível (Chitarra \& Chitarra, 1990). Jubes \& Foguet (1971), citados por Souza (1990), estudando o comportamento de hastes de abacateiro (Persea americana), conservadas durante 30 e 70 dias, concluíram que os melhores resultados foram obtidos quando as hastes foram mantidas em sacos de polietileno à temperatura de $3-5^{\circ} \mathrm{C}$. Snyder \& Hess (1956) trabalharam com armazenamento de estacas enraizadas de diversas espécies ornamentais (Juniperus communis hibernica, Taxus cuspidata, Teucrium chamaedrys, Thuja occidentalis globosa e Thuja occidnetalis piramidalis), tendo como resultado que a armazenagem em sacos plásticos com ou sem esfagno ou vermiculita foram igualmente satisfatórias. Em seguida Flint \& McGuire (1960) usando estacas enraizadas de 7 espécies ornamentais acondicionadas em sacos de polietileno, conseguiram até $100 \%$ de sobrevivência das estacas após 4 meses de armazenamento, porém houve declínio acentuado quando o período foi estendido para 6 meses. Observaram também grande variação entre espécies e variedades e temperatura de armazenamento.

Embora seja de uso corrente no acondicionamento de estacas apicais herbáceas de crisântemo e mudinhas de violetas é rara a utilização de sacos de polietileno por produtores de estacas de plantas ornamentais lenhosas no Brasil.

Os produtores de estacas de dracenas no Estado de São Paulo recobrem a porção distal das estacas com uma pasta de parafina e cimento Portland, ou no caso de macro-estacas (com mais de 1,0 m de comprimento) colocam vermiculita umedecida na base envolvida por um filme plástico, preso por elástico. Tendo incluído estes sistemas em suas investigações, Reis et al. (1997) observaram que a percentagem de enraizamento de estacas de Polyscias guilfoylei 
armazenadas por 30, 60 e 90 dias não diferiu estatisticamente entre aquelas armazenadas em sacos plásticos e aquelas recobertas (na base e ápice) com pasta de parafina e cimento Portland. Os autores recomendam o uso de filme plástico para estacas de $P$. guilfoylei em detrimento de pasta de parafina pela praticidade do primeiro. Outros tratamentos incluíram: pasta no ápice da estaca; pasta no ápice e vermiculita na base da estaca; sem proteção superficial, mas com a base da estaca mantida em água.

Películas de amido e fécula têm sido mais recentemente empregadas na conservação pós-colheita de produtos hortícolas. Por exemplo, película de amido (1\%) e de fécula (1\%), bem como cera "Sta-fresh" foram empregados por Vietes et al. (1996) para avaliar a perda de peso, mudança de coloração e variação de textura em tomates mantidos em estufa $B O D$ a $10^{\circ} \mathrm{C}$ por 30 dias. Observou-se que a perda de clorofila foi retardada nos tomates tratados com película de amido, muito embora frutos tratados com cera apresentaram melhor textura e menor perda de peso. Oliveira (1996) relata o uso de película de fécula de mandioca a 1 ou $2 \%$ como alternativa viável à utilização de cera comercial na conservação pós-colheita de frutos de goiaba, necessitando apenas de ajustes para diminuir a perda de massa dos frutos. O mesmo autor relata ainda que concentrações mais elevadas da película de fécula (3 e 5\%) impediu a maturação dos frutos, acarretou distúrbios fisiológicos nos mesmos. Os frutos não desenvolveram a coloração e texturas desejadas e apresentaram menores valores de vitamina C. Henrique (1999) empregou obteve maior rendimento de suco em limão siciliano quando tratado com etephon $(2.000 \mathrm{mg} / \mathrm{L})$ e recobertos com película de fécula de mandioca a $3 \%$. Esta última ainda proporcionou maior brilho aos frutos, podendo substituir a cera comercial nesta característica. O uso de película de fécula de mandioca em couve-flor, segundo Vicentini (1999), resultou em textura mais firme, menor acidez titulável e redução da taxa de respiração, além do que inflorescências recobertas com película a $4 \%$ de concentração mostraram-se superiores as demais.

Portanto é muito interessante que se estabeleça um teste comparativo entre o uso de película de fécula de mandioca e demais métodos de uso corrente para recobrimento de estacas de cordiline. 


\section{MATERIAL E MÉTODOS}

\section{1 Local}

O experimento foi conduzido nas dependências do Departamento de Produção Vegetal da Escola Superior de Agricultura "Luiz de Queiroz"/USP.

\section{2 Material vegetal}

\section{2. 1 Matrizes de Cordyline rubra Hügel}

O material vegetal foi fornecido pela empresa Plantas Exóticas do Brasil Agri Floricultura Ltda, de Juquiá - SP.

As plantas matrizes (Figura 2), de onde se obtiveram as estacas, foram cultivadas a pleno sol, com idades variando entre 4 e 8 anos, em condições de elevada umidade relativa do ar e sob irrigação por aspersão.

O clima da região é do tipo tropical e subtropical quente e úmido. A temperatura média é de $28^{\circ} \mathrm{C}$, sendo que no verão pode ultrapassar $37^{\circ} \mathrm{C}$ e no inverno chegar abaixo de $10^{\circ} \mathrm{C}$. $\mathrm{O}$ relevo é fortemente acidentado, com declividade de $20^{\circ}$ a $70^{\circ}$. O solo é constituído por latossolo amarelo, pobre e ácido (Juquiá: informações, 2005). 


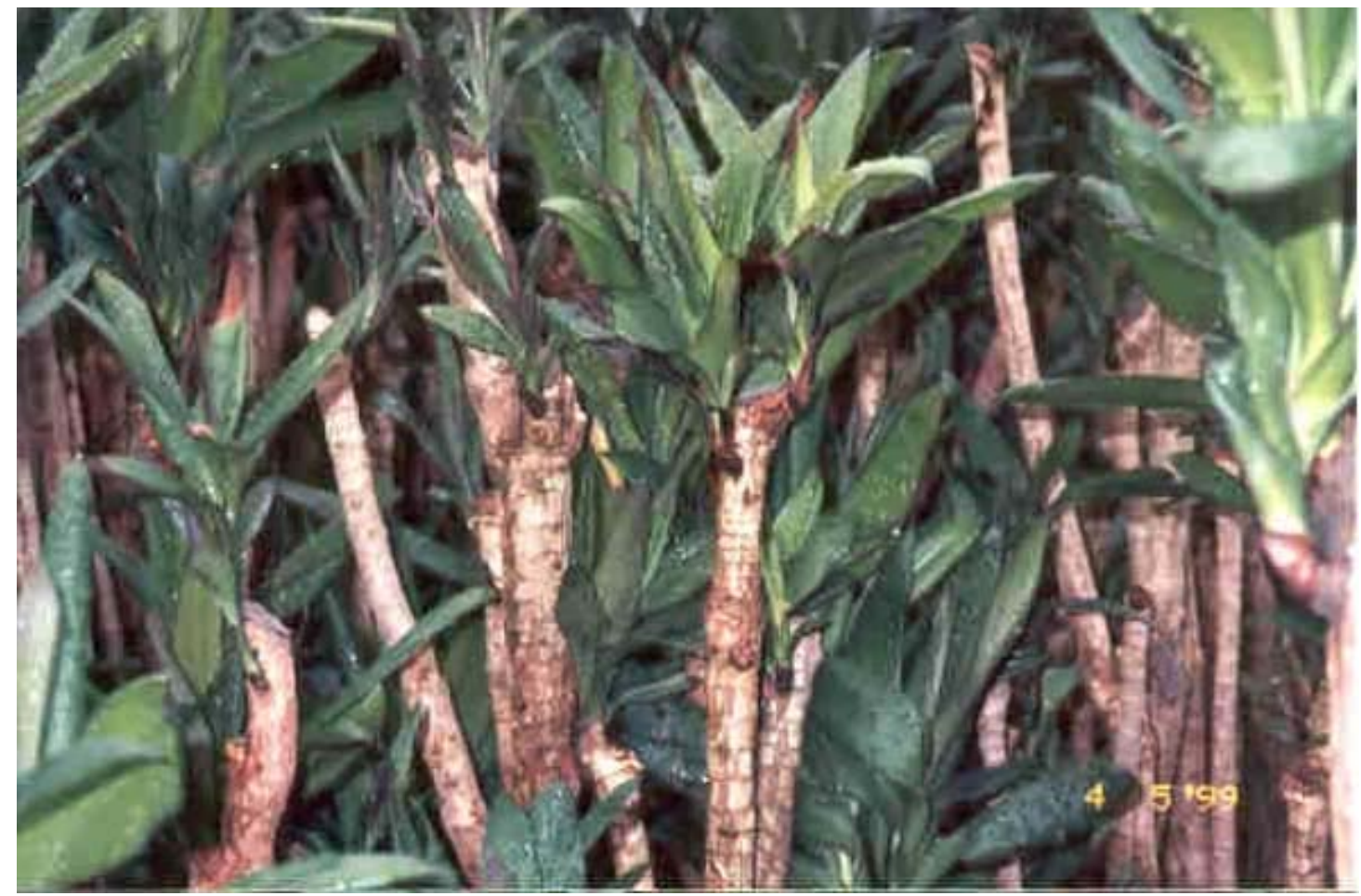

Figura 2 - Aspecto geral do matrizeiro de C. rubra (Arquivo pessoal, 1999)

\section{2. 2 Obtenção e preparo preliminar das estacas}

Para que se pudesse verificar diferenças sazonais no enraizamento do material armazenado, as estacas foram retiradas em duas épocas do ano: novembro e junho, ou seja, primavera e outono. Foram utilizadas 615 estacas sem folhas, cortadas em serra circular, com comprimento de $30 \mathrm{~cm}$ e com diâmetro de $3,0 \mathrm{~cm}$. As estacas foram obtidas da porção mediana dos ramos, descartando-se as porções apicais e basais.

\section{3 Instalação e condução do experimento}

As estacas foram separadas em 5 lotes de 120 estacas, sendo cada lote submetido a um dos pré-tratamentos (tipos de recobrimento) que se seguem:

a) recobertas com película de fécula de mandioca a $3 \%$ fornecida pelo Centro de Raízes e Amidos Tropicais/UNESP; 
b) recobrimento da parte apical das estacas com pasta feita a partir de parafina fundida e cimento Portland (5:2 em peso);

c) com porção apical tratada com pasta de parafina fundida e cimento Portland (5:2 em peso) e a parte basal inserida em um saquinho plástico contendo $10 \mathrm{~g}$ de vermiculita umedecida;

d) acondicionadas em saco plástico transparente e fechado;

e) mantidas na horizontal apenas com tratamento químico de desinfestação;

Os tratamentos de recobrimento podem ser visualizados na Figura 3.

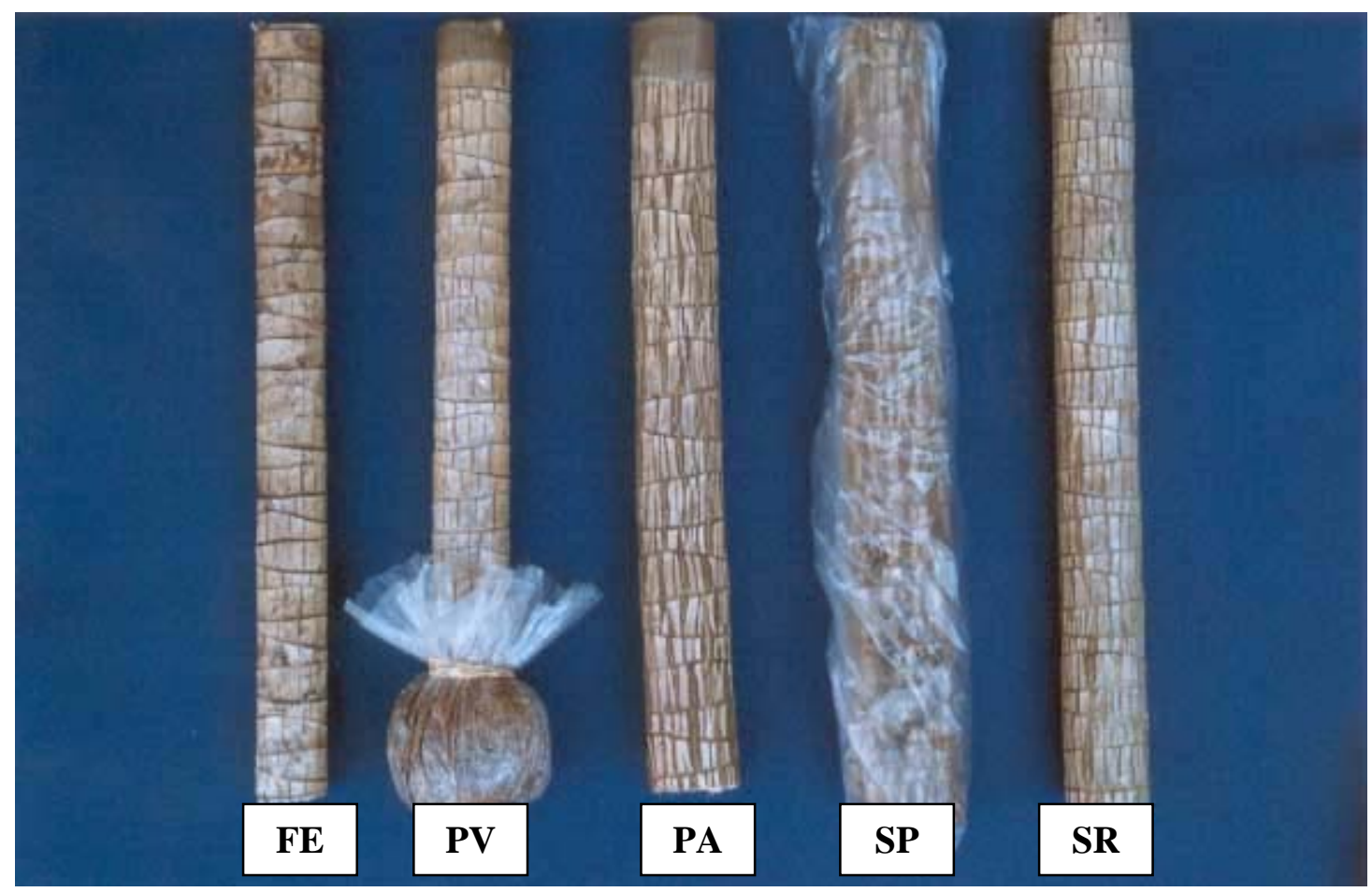

Figura 3 - Tipos de recobrimento de estacas de C. rubra. Da esquerda para a direita; FE-Fécula de mandioca; PV-Parafina no ápice e vermiculita na base; PA-Parafina no ápice; SPSaco plástico; e SR-Sem recobrimento (Arquivo pessoal, 2002)

O lote testemunha foi composto de 15 estacas colocadas para enraizar em areia, sob irrigação (diária), em local sombreado ( $50 \%$ de luminosidade), sem passar por período de armazenamento.

Cada tratamento foi composto de 30 estacas pré-tratadas as quais foram submetidas a diferentes períodos de armazenamento, a saber, 30, 60, 90 ou 120 dias, totalizando 120 estacas por pré-tratamento. Estas foram divididas em dois sub-tratamentos, sendo que um 
deles foi destinado ao armazenamento em temperatura ambiente $\left(22-32^{\circ} \mathrm{C}\right)$ e os demais foram destinados à câmara fria $\left(10^{\circ} \mathrm{C}\right)$. Em ambos os casos tais estacas foram mantidas na posição horizontal e no escuro.

Ao final do período de 30, 60, 90 ou 120 dias de armazenamento (temperatura ambiente ou refrigerada) as estacas foram etiquetadas e transferidas aleatoriamente para o leito de enraizamento para enraizamento, após as suas partes basais serem cortadas com o uso de uma serra circular e tratadas com AIB a $10.000 \mathrm{mg} / \mathrm{L}$, sob as mesmas condições adotadas para o tratamento testemunha.

Para facilitar o entendimento dos tratamentos, foram utilizados os seguintes códigos:

- FE/R - estacas recobertas com película de fécula de mandioca, armazenadas em ambiente refrigerado;

- PV/R - estacas recobertas com pasta de parafina no ápice e vermiculita umedecida na base, armazenadas em ambiente refrigerado;

- PA/R - estacas recobertas com pasta de parafina no ápice, armazenadas em ambiente refrigerado;

- SP/R - estacas embaladas em saco plástico, armazenadas em ambiente refrigerado;

- SR/R - estacas mantidas na posição horizontal, sem recobrimento, armazenadas em ambiente refrigerado;

- FEIA - estacas recobertas com película de fécula de mandioca, armazenadas em temperatura ambiente;

- PVIA - estacas recobertas com pasta de parafina no ápice e vermiculita umedecida na base, armazenadas em temperatura ambiente;

- PAlA - estacas recobertas com pasta de parafina no ápice, armazenadas em ambiente refrigerado;

- SPIA - estacas embaladas em saco plástico, armazenadas em temperatura ambiente;

- SRIA - estacas mantidas na posição horizontal, sem recobrimento, armazenadas em ambiente refrigerado;

- $\quad$ TT - tratamento testemunha, sem período de armazenamento. 


\section{3. 1 Obtenção e preparo do amido}

O amido utilizado foi fornecido pelo CERAT - Centro de Raízes e Amidos Tropicais UNESP - Campus de Botucatu/SP.

O gel de amido natural de mandioca utilizado foi preparado conforme o fluxograma a seguir:

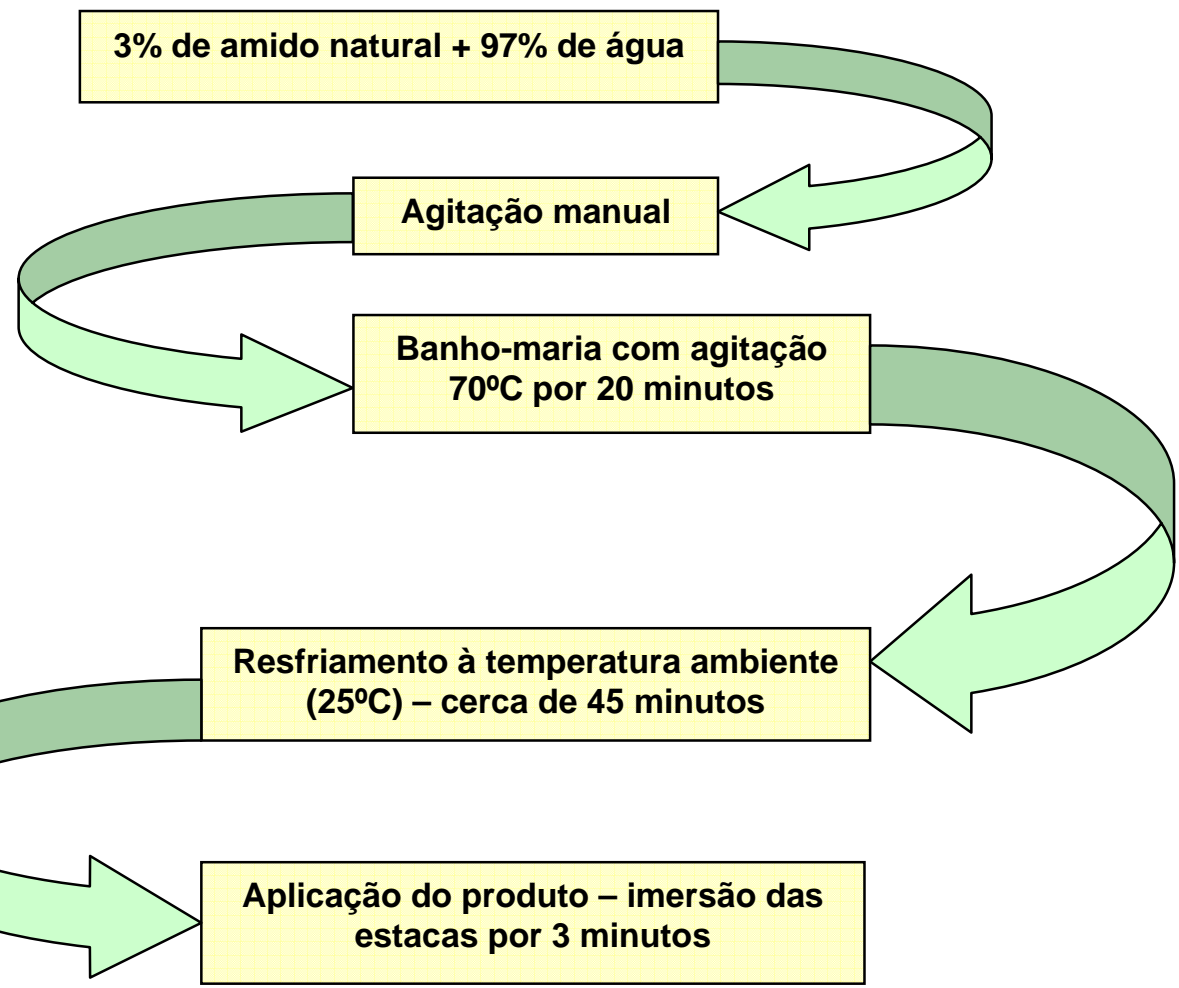

Figura 4 - Fluxograma de preparo da suspensão e produção de filme amiláceo, a partir do amido natural

\section{4 Delineamento estatístico}

O delineamento experimental é o inteiramente casualizado no esquema fatorial 2X4X5 mais um tratamento adicional (testemunha). Foram empregadas 2 temperaturas (ambiente e refrigerada), 4 períodos de armazenamento (30,60, 90 ou 120 dias) e 5 tipos de recobrimento (fécula de mandioca, parafina no ápice, parafina no ápice e vermiculita umedecida na base, saco plástico e apenas armazenadas na posição horizontal), com 15 repetições (estacas). 


\section{5 Parâmetros avaliados}

\section{5. 1 Análises físicas}

Da mesma forma que a testemunha (TT), a avaliação do enraizamento e brotação das estacas foi programada para ser feita 90 dias após serem colocadas em leito de enraizamento de areia grossa.

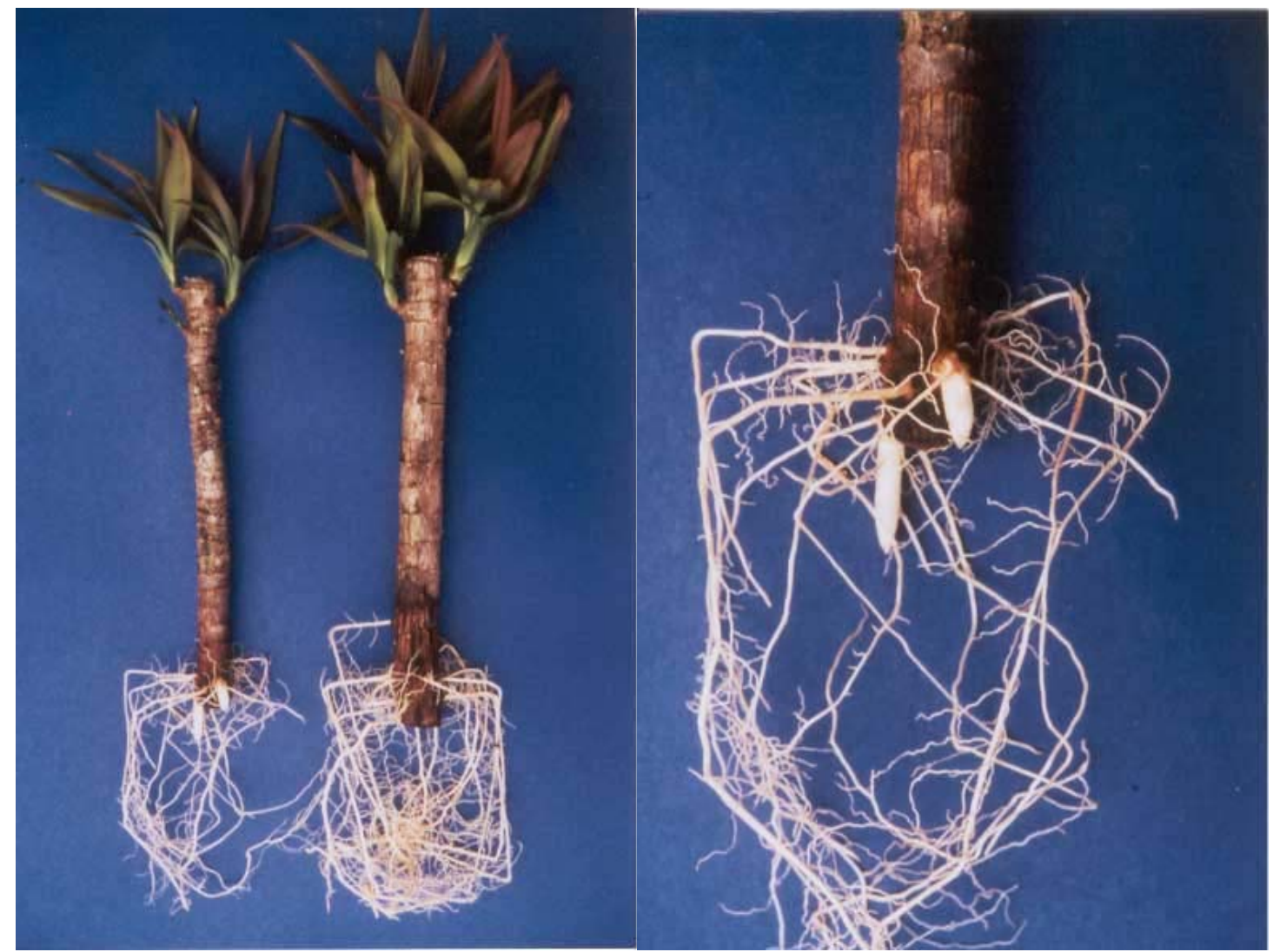

Figura 5 - Aspecto de plantas de C. rubra, retiradas do leito de enraizamento, após 90 dias, para análises físicas, com detalhe dos rizomas à direita (Arquivo pessoal, 2002)

Para coleta e análise de resultados foram consideradas aa porcentagens de estacas brotadas e/ou enraizadas, o número de brotos e raízes por estaca e a massa de matéria fresca de brotos e raízes. A matéria seca de brotos e raízes foi avaliada após a estabilização da massa em estufa a $65^{\circ} \mathrm{C}$ (cerca de 4 dias). 


\section{5. 2 Análises estatísticas}

Os dados foram analisados através do teste $\mathrm{F}$ de análise da variância e posteriormente os tratamentos foram comparados por um teste de comparação de médias. Foi utilizado o software estatístico SAS para as análises. 


\section{RESULTADOS E DISCUSSÃO}

De um modo geral, vários autores (Flint \& McGuire, 1960; Poole \& Conover,1992; Reis, 1998; Souza, 1990) relatam que com o aumento do período de armazenamento, a tendência é do percentual de enraizamento diminuir. Outros relatos mostram que resultados melhores são obtidos com estacas armazenadas em ambiente refrigerado (Jubes \& Foguet, 1971; Poole \& Conover, 1992; Souza, 1990).

A seguir são apresentados os resultados de acordo com o efeito sazonal de estacas colhidas na primavera ou outono e dentro de cada estação do ano todos os fatores estudados: refrigeração, tipos de recobrimento e períodos de armazenamento.

\section{1 Estacas obtidas na primavera.}

\section{1. 1 Desenvolvimento de brotos, raízes e formação de rizomas.}

A Tabela 1 apresenta os valores percentuais de estacas que desenvolveram brotos, raízes e rizomas, respectivamente, subdivididos de acordo com os recobrimentos empregados além do tratamento testemunha para $C$. rubra. De um modo geral, pode-se dizer que melhores resultados foram obtidos quando as estacas foram submetidas a menores períodos de armazenamento e mantidas em ambiente refrigerado e aparentemente, os tratamentos que melhores resultados apresentaram foram os que envolveram o uso do saco plástico e o emprego da parafina no ápice conjuntamente com a vermiculita umedecida na base. 
Tabela 1. Percentual do desenvolvimento de brotos, raízes e rizomas em estacas de primavera de C. rubra, armazenadas por 30, 60, 90 ou 120 dias, em condições de temperatura ambiente ou refrigerada e submetidas aos diferentes tipos de recobrimento

\begin{tabular}{|c|c|c|c|c|c|c|c|c|c|c|c|c|}
\hline \multirow{3}{*}{ Tipos de Recobrimento } & \multirow{2}{*}{\multicolumn{4}{|c|}{ Estacas com Brotos (\%) }} & \multirow{2}{*}{\multicolumn{4}{|c|}{$\begin{array}{c}\text { Período de Armazenamento (dias) } \\
\text { Estacas com Raízes (\%) }\end{array}$}} & \multirow{2}{*}{\multicolumn{4}{|c|}{ Estacas com Rizomas (\%) }} \\
\hline & & & & & & & & & & & & \\
\hline & 30 & 60 & 90 & 120 & 30 & 60 & 90 & 120 & 30 & 60 & 90 & 120 \\
\hline $\mathrm{FE} / \mathrm{R}$ & 100,00 & 66,67 & 33,33 & 0,00 & 100,00 & 60,00 & 40,00 & 0,00 & 13,33 & 20,00 & 6,67 & 0,00 \\
\hline $\mathrm{PV} / \mathrm{R}$ & 100,00 & 80,00 & 80,00 & 73,33 & 93,33 & 93,33 & 86,67 & 73,33 & 46,67 & 46,67 & 46,67 & 6,67 \\
\hline $\mathrm{PA} / \mathrm{R}$ & 93,33 & 93,33 & 80,00 & 6,67 & 100,00 & 93,33 & 66,67 & 6,67 & 53,33 & 40,00 & 20,00 & 0,00 \\
\hline $\mathrm{SP} / \mathrm{R}$ & 100,00 & 80,00 & 100,00 & 73,33 & 100,00 & 80,00 & 100,00 & 73,33 & 66,67 & 20,00 & 46,67 & 6,67 \\
\hline $\mathrm{SR} / \mathrm{R}$ & 100,00 & 80,00 & 13,33 & 0,00 & 100,00 & 73,33 & 26,67 & 0,00 & 53,33 & 13,33 & 0,00 & 0,00 \\
\hline $\mathrm{FE} / \mathrm{A}$ & 66,67 & 0,00 & 0,00 & 0,00 & 73,33 & 0,00 & 0,00 & 0,00 & 13,33 & 0,00 & 0,00 & 0,00 \\
\hline $\mathrm{PV} / \mathrm{A}$ & 73,33 & 66,67 & 73,33 & 33,33 & 73,33 & 66,67 & 73,33 & 40,00 & 20,00 & 20,00 & 20,00 & 6,67 \\
\hline $\mathrm{PA} / \mathrm{A}$ & 93,33 & 13,33 & 6,67 & 0,00 & 93,33 & 6,67 & 6,67 & 0,00 & 53,33 & 6,67 & 0,00 & 0,00 \\
\hline SP/A & 100,00 & 73,33 & 60,00 & 20,00 & 93,33 & 73,33 & 66,67 & 26,67 & 66,67 & 33,33 & 33,33 & 0,00 \\
\hline $\mathrm{SR} / \mathrm{A}$ & 73,33 & 0,00 & 0,00 & 0,00 & 66,67 & 0,00 & 0,00 & 0,00 & 13,33 & 0,00 & 0,00 & 0,00 \\
\hline $\mathrm{TT}^{*}$ & 93,33 & - & - & - & 93,33 & - & - & - & 0,00 & - & - & - \\
\hline
\end{tabular}

FE - fécula de mandioca; PV - parafina + vermiculita; PA - parafina no ápice; SP - saco plástico; SR - sem recobrimento; TT - testemunha; R - sob refrigeração; A emperatura ambiente.

*sem armazenamento 
De acordo com a Tabela 1, para estacas de C. rubra colhidas na primavera, todos os tratamentos mantidos em ambiente refrigerado podem ser recomendados para um bom enraizamento, até 30 dias de armazenamento, por apresentarem boas porcentagens: FE/R (100,00\%), PV/R (93,33\%), PA/R (100,00\%), SP/R (100,00\%) e SR/R (100,00\%); para temperatura ambiente o melhor enraizamento foi encontrado nos tratamentos $\mathrm{PA} / \mathrm{A}(93,33 \%)$, SP/A (93,33\%), FE/A (73,33\%) e PV/A (73,33\%). Para 60 dias de armazenamento, bons resultados foram observados em ambiente refrigerado nos tratamentos $\mathrm{PV} / \mathrm{R}(93,33 \%), \mathrm{PA} / \mathrm{R}$ (93,33\%) e SP/R (80,00\%); em temperatura ambiente, se destacou apenas SP/A (73,33\%). Até 90 dias de armazenamento em ambiente refrigerado, apenas PV/R (86,67\%) e SP/R (100,00\%) tiveram resultados satisfatórios de enraizamento, enquanto que em temperatura ambiente, somente PV/A (73,33\%) teve um bom enraizamento. Já para 120 dias de armazenamento, somente os tratamentos PV/R (73,33\%) e SP/R (73,33\%) em ambiente refrigerado mostraram bom enraizamento. Os demais tratamentos não mostraram bons resultados.

Pode-se observar que o tratamento testemunha (TT) não apresentou formação de rizomas, desse modo, para 30 dias de armazenamento, todos os tratamentos apresentaram resultados melhores que a testemunha, sendo que se destacaram dos demais, SP/R e SP/A com $66,67 \%$ e PA/R e PA/A com 53,33\%. Para 60 dias de armazenamento, apenas FE/A e $\mathrm{SR} / \mathrm{A}$ não apresentaram formação de rizomas como a testemunha. Aos 90 dias, observa-se que $\mathrm{SR} / \mathrm{R}, \mathrm{FE} / \mathrm{R}, \mathrm{PA} / \mathrm{A}$ e SR/A não apresentaram formação de rizomas. Em 120 dias de armazenamento, apenas $P V / R, S P / R$ e $P V / A$ apresentaram $6,67 \%$ de formação de rizomas.

Souza (1990), demonstrou que estacas parafinadas de seringueira (Hevea brasiliensis) destinadas a enxertia, apresentaram melhores resultados de armazenamento até 8 dias. Porém com o aumento do tempo de armazenamento, houve um decréscimo no sucesso da enxertia e o índice de pegamento tornou-se nulo após 16 dias para hastes armazenadas em meio ambiente, câmara fria, extremidades parafinadas e serragem curtida umedecida, confirmando os resultados obtidos no presente experimento, onde as estacas de cordiline perdiam sua viabilidade a medida que aumentava o período de armazenamento.

Em geral, estacas que tiveram um bom percentual de desenvolvimento de brotos, raízes e rizomas, demonstraram também, valores médios de número, massa de matéria fresca e massa de matéria seca de raízes, brotos e rizomas. Do mesmo modo pode-se dizer que os melhores tratamentos de recobrimento salientados a seguir apresentaram bons resultados, em termos absolutos, para todos os períodos de armazenamento, apesar de que em termos relativos, estatisticamente alguns resultados não foram significativamente melhores do que o tratamento testemunha. 


\section{1. 2 Valores médios de número, massas de matéria fresca e seca de brotos, raízes e rizomas}

A Tabela 2 mostra as médias do número de brotações de parte aérea, observados em 30, 60, 90 ou 120 dias de armazenamento, em condições de temperatura ambiente ou refrigerada para estacas de primavera de C. rubra para os diferentes tipos de recobrimento, mais a testemunha. Nota-se que os melhores resultados obtidos foram alcançados com a manutenção das estacas em ambiente refrigerado e o emprego de saco plástico e parafina aplicada no ápice e vermiculita na base.

Tabela 2. Médias do número de brotos desenvolvidos em estacas de primavera de $C$. rubra, armazenadas por 30,60, 90 ou 120 dias, em condições de temperatura ambiente ou refrigerada e submetidas aos diferentes tipos de recobrimento

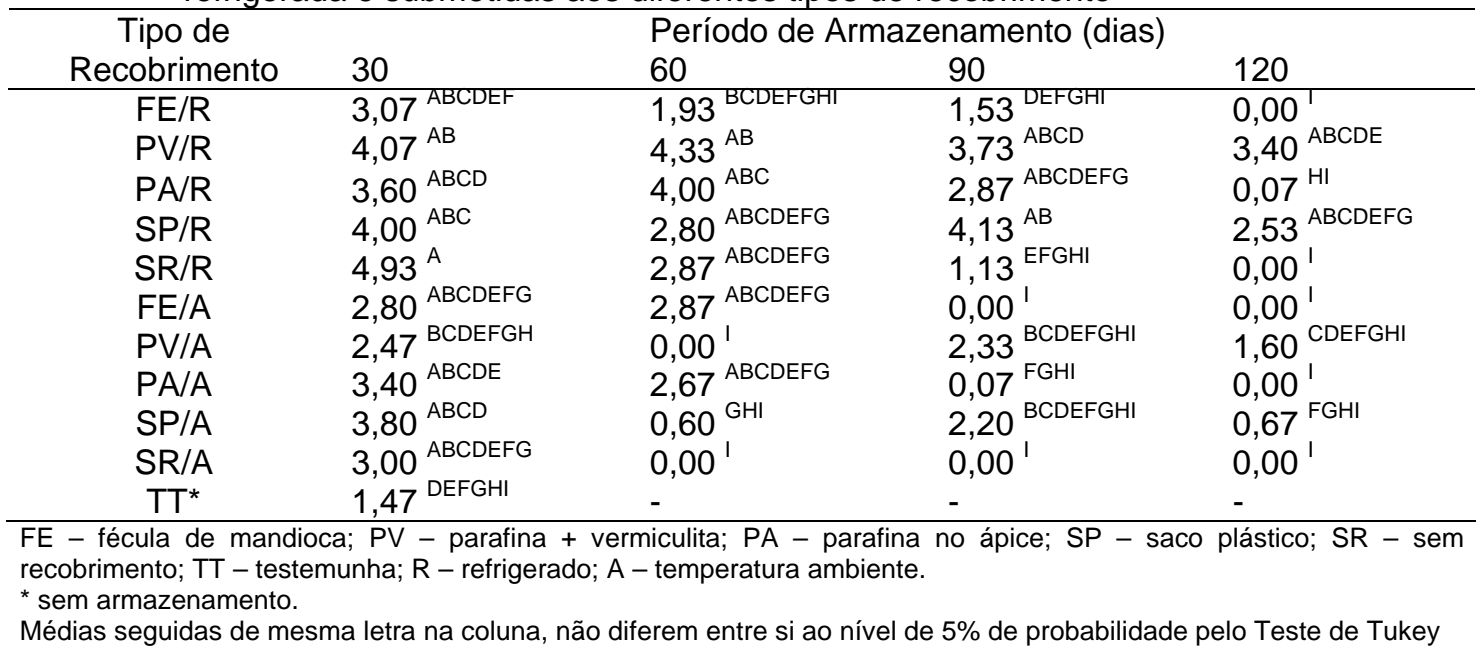

Pela Tabela 2, de média do número de brotações por estaca, nota-se que houve diferença estatística entre alguns tratamentos e a testemunha. O tratamento SR/R, com 4,93, PV/R com 4,07 e SP/R com 4,00 brotações para 30 dias de armazenamento foram os que proporcionaram maiores números de brotos, superando estatisticamente TT, que apresentou apenas uma média de 1,47 brotações por estaca.

Aos 60 dias de armazenamento, os tratamentos que tiveram melhores resultados (que diferiram estatisticamente de TT foram PV/R $(4,33)$ e PA/R $(4,00)$.

Aos 90 dias, somente SP/R apresentou diferenças significativas em relação à TT, com 4,13 brotações.

Para 120 dias de armazenamento, nenhum tratamento foi significativamente melhor que o tratamento testemunha. 
A Tabela 3 mostra as médias de produção de matéria fresca (em gramas) de parte aérea, observadas em 30, 60, 90 ou 120 dias de armazenamento, em condições de temperatura ambiente ou refrigerada para estacas de primavera de $C$. rubra para os diferentes tratamentos de recobrimento, mais a testemunha.

Tabela 3. Médias das massas de matéria fresca de brotos, em gramas, desenvolvidos em estacas de primavera de C. rubra, armazenadas por 30, 60, 90 ou 120 dias, em condições de temperatura ambiente ou refrigerada e submetidas aos diferentes tipos de recobrimento

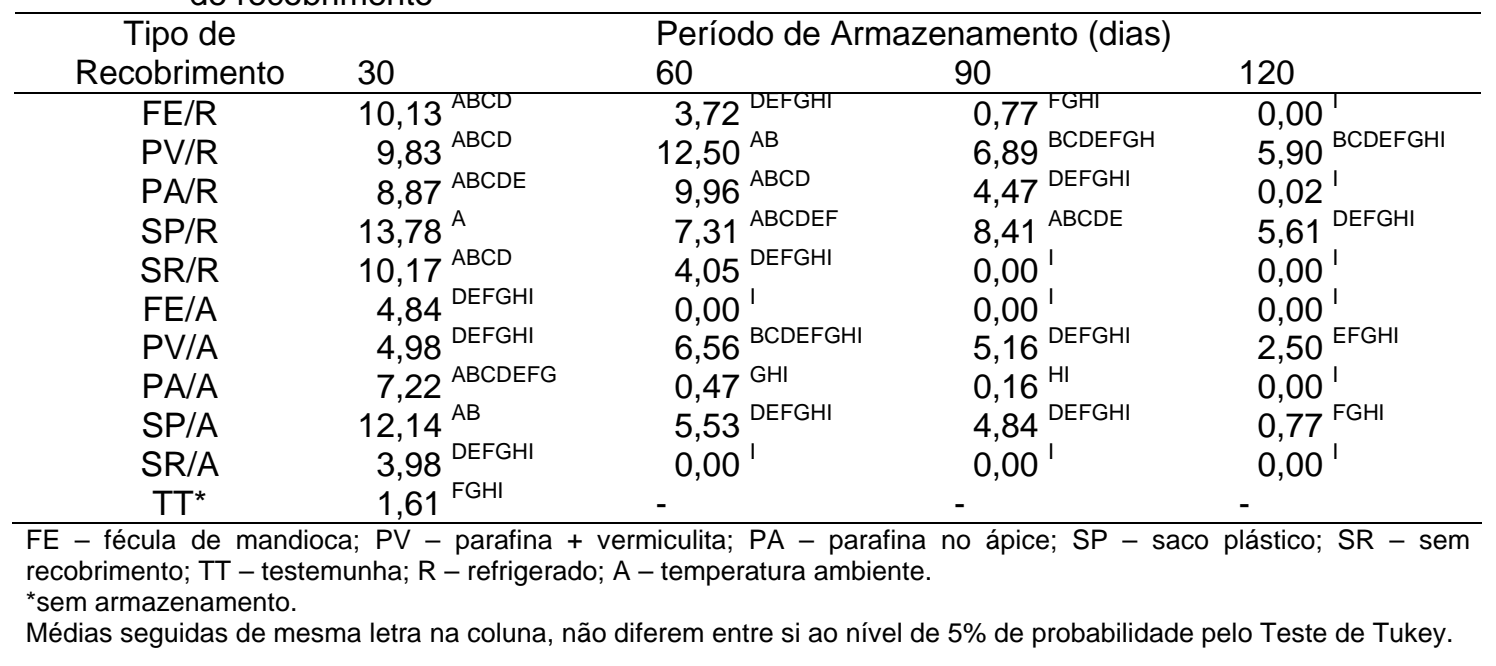

Pela Tabela 3, de média de massa de matéria fresca de brotos, pode-se observar que 0 melhor resultado foi obtido no tratamento SP/R (embaladas em saco plástico e armazenadas em ambiente refrigerado), com 13,78g, superando TT com 1,61g.

Para 30 dias de armazenamento, todos os tratamentos conservados em ambiente refrigerado ( $F E / R-10,13 g, P V / R-9,83 g, P A / R-8,87 g, S P / R-13,78 g$ e $S R / R-10,17 g$ ) além do tratamento SP/A $(12,14 \mathrm{~g})$ tiveram resultados estatisticamente melhores que TT.

Aos 60 dias de armazenamento, apenas os tratamentos PV/R com 12,50g e PA/R com $9,96 \mathrm{~g}$ foram estatisticamente melhores que TT.

Para 90 dias, somente SP/R, com 8,41g diferiu de TT, sendo que para 120 dias de armazenamento nenhum tratamento superou o TT estatisticamente.

A Tabela 4 mostra as médias de produção de matéria seca (em gramas) de parte aérea, observados em 30, 60, 90 ou 120 dias de armazenamento, em condições de temperatura ambiente ou refrigerada para estacas de primavera de C. rubra, para os diferentes tipos de recobrimento, mais a testemunha. 
Tabela 4. Médias das massas de matéria seca de brotos, em gramas, desenvolvidos em estacas de primavera de C. rubra, armazenadas por 30, 60, 90 ou 120 dias, em condições de temperatura ambiente ou refrigerada e submetidas aos diferentes tipos de recobrimento

\begin{tabular}{|c|c|c|c|c|}
\hline \multirow{2}{*}{$\begin{array}{c}\text { Tipo de } \\
\text { Recobrimento }\end{array}$} & \multicolumn{4}{|c|}{ Período de Armazenamento (dias) } \\
\hline & 30 & 60 & 90 & 120 \\
\hline $\mathrm{FE} / \mathrm{R}$ & $1,77^{\mathrm{ABCD}}$ & $0,59^{\text {DEFGH }}$ & $0,11^{\mathrm{FGH}}$ & 0,00 \\
\hline $\mathrm{PV} / \mathrm{R}$ & $1,76^{\mathrm{ABCDE}}$ & $2,15^{\mathrm{ABC}}$ & $1,32^{\mathrm{BCDEF}}$ & $1,07^{\mathrm{BCDEFGH}}$ \\
\hline $\mathrm{PA} / \mathrm{R}$ & $1,73^{A B C D E}$ & $1,65^{A B C D E}$ & $0,79^{\mathrm{DEFGH}}$ & $0,00 \mathrm{GH}$ \\
\hline $\mathrm{SP} / \mathrm{R}$ & $2,76^{\mathrm{A}}$ & $1,27^{\mathrm{BCDEFG}}$ & $1,62^{\mathrm{ABCDE}}$ & $1,03^{\text {BCDEFGH }}$ \\
\hline $\mathrm{SR} / \mathrm{R}$ & $1,85^{\mathrm{ABCD}}$ & $0,61^{\mathrm{DEFGH}}$ & $0,07^{\mathrm{FGH}}$ & $0,00^{\prime}$ \\
\hline $\mathrm{FE} / \mathrm{A}$ & $0,78^{\text {DEFGH }}$ & $0,00^{\prime}$ & $0,00^{\prime}$ & $0,00^{\prime}$ \\
\hline $\mathrm{PV} / \mathrm{A}$ & 0,92 CDEFGH & $1,17^{\mathrm{BCDEFGH}}$ & $1,02^{B C D E F G H}$ & 0,49 EFGH \\
\hline $\mathrm{PA} / \mathrm{A}$ & $1,32^{\mathrm{BCDEF}}$ & $0,08^{\mathrm{FGH}}$ & $0,02 \mathrm{GH}$ & $0,00^{\prime}$ \\
\hline SP/A & $2,23{ }^{A B}$ & $1,04^{B C D E F G H}$ & $0,94 \mathrm{CDEFGH}$ & $0,13^{\mathrm{FGH}}$ \\
\hline $\mathrm{SR} / \mathrm{A}$ & $0,62^{\text {DEFGH }}$ & $0,00^{\prime}$ & $0,00^{1}$ & $0,00^{\prime}$ \\
\hline $\mathrm{TT}^{*}$ & $0,24{ }^{\mathrm{FGH}}$ & , & - & - \\
\hline
\end{tabular}

FE - fécula de mandioca; PV - parafina + vermiculita; PA - parafina no ápice; SP - saco plástico; SR - sem recobrimento; $T T$ - testemunha; $R$ - refrigerado; $A$ - temperatura ambiente.

* sem armazenamento.

Médias seguidas de mesma letra na coluna, não diferem entre si ao nível de $5 \%$ de probabilidade pelo Teste de Tukey.

$\mathrm{Na}$ Tabela 4, de média de massa de matéria seca de brotos, pode-se confirmar que o melhor resultado foi obtido no tratamento SP/R (embaladas em saco plástico e armazenadas em ambiente refrigerado), com 2,76g, sendo coerente com os valores da Tabela 7 . Sendo que os melhores resultados, os quais não diferiram estatisticamente entre si, são os tratamentos PV/R, com 1,76g, SP/R com 2,76g, FE/R com 1,77g, PA/R com 1,73g, SR/R com 1,85g e SP/A que se saiu muito bem com 2,23g para 30 dias de armazenamento.

Aos 60 dias de armazenamento, os tratamentos que não diferiram estatisticamente dos melhores resultados foram PV/R com 2,15g e PA/R com 1,65g.

Para 90 dias, o único tratamento que foi estatisticamente igual aos melhores tratamentos foi SP/R, com 1,62g.

Após 90 dias de armazenamento, nenhum tratamento mostrou resultados satisfatórios.

O resultado apresentado por TT $(0,24 \mathrm{~g})$ foi muito baixo em relação aos melhores tratamentos.

A Tabela 5 apresenta as médias do número de raízes, observadas aos $30,60,90$ ou 120 dias de armazenamento em condições de temperatura ambiente ou refrigerada para estacas de primavera de $C$. rubra para os diferentes tratamentos de recobrimento, mais a testemunha. Mais uma vez observa-se que os tratamentos armazenados em ambiente refrigerado, em conjunto com menores períodos de armazenamento foram os que apresentaram melhores resultados. 
Tabela 5. Médias dos números de raízes desenvolvidas em estacas de primavera de $C$. rubra, armazenadas por $30,60,90$ ou 120 dias, em condições de temperatura ambiente ou refrigerada e submetidas aos diferentes tipos de recobrimento

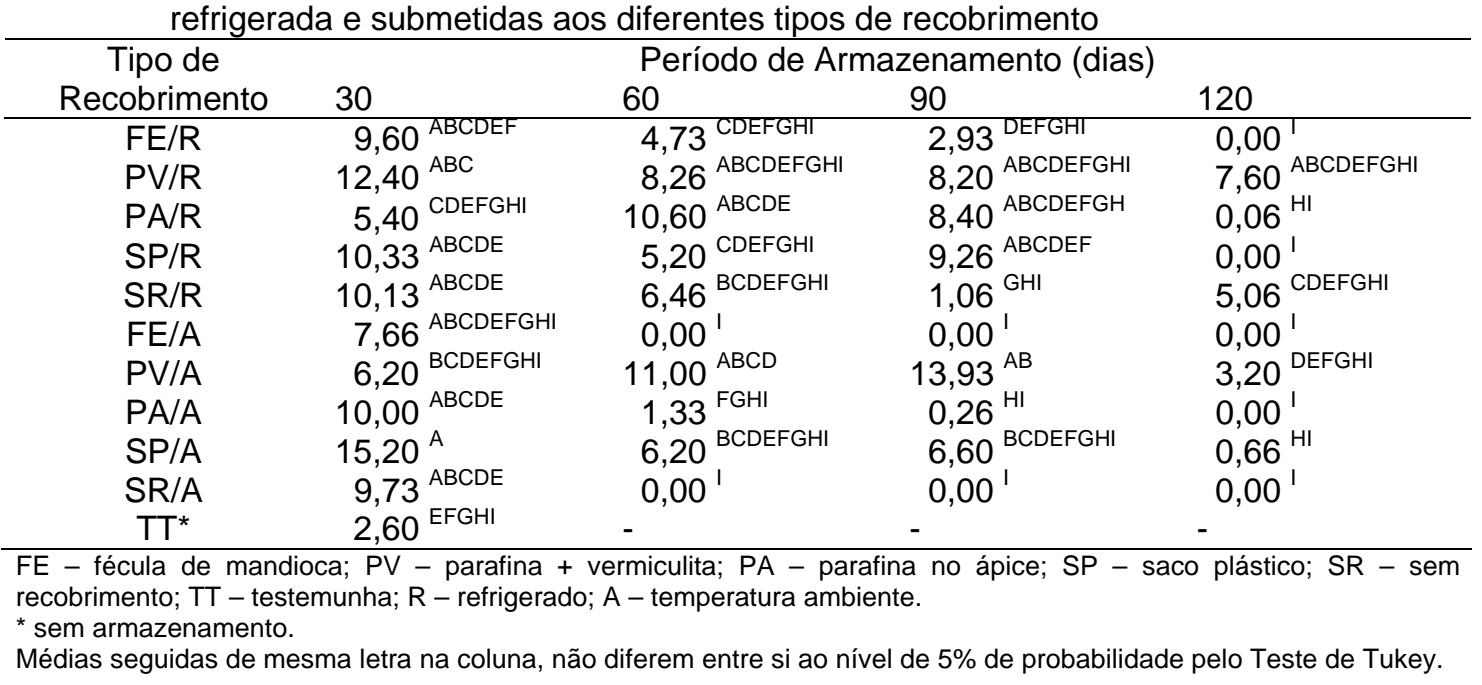

Segundo a Tabela 5, o tratamento testemunha apresentou resultado de 2,60 raízes por estaca, sendo ultrapassado por diversos outros tratamentos.

Aos 30 dias de armazenamento, pode-se observar que apenas os tratamentos SP/A com 15,20 raízes e PV/R com 12,40 raízes diferem estatisticamente do tratamento testemunha TT com 2,60 raízes.

O tratamento que diferiu estatisticamente da testemunha foi o PV/A, para 60 e 90 dias de armazenamento, com 11,00 e 13,93 raízes, respectivamente.

Aos 120 dias, não se observa diferenças estatísticas em relação à TT, sendo que muitos tratamentos não enraizaram e por tanto os valores dos resultados foram computados como sendo zero. Apesar de baixos, os melhores resultados para esse período foram obtidos nos tratamentos $P V / R$, com 7,60 raízes e $S R / R$, com 5,06 raízes.

Apesar de muitos tratamentos não terem sido estatisticamente melhores que a testemunha, apresentaram porém bons resultados em valores absolutos. Os recobrimentos com 30 dias de armazenamento podem ser citados como exemplo neste caso.

A Tabela 6 apresenta médias de massa de matéria fresca de raízes (em gramas), observados aos $30,60,90$ ou 120 dias de armazenamento em condições de temperatura ambiente ou refrigerada para estacas de primavera de $C$. rubra para os diferentes tipos de recobrimento, mais a testemunha. 
Tabela 6. Médias das massas de matéria fresca de raízes, em gramas, desenvolvidas em estacas de primavera de C. rubra, armazenadas por 30, 60, 90 ou 120 dias, em condições de temperatura ambiente ou refrigerada e submetidas aos diferentes tipos de recobrimento

\begin{tabular}{|c|c|c|c|c|}
\hline \multirow{2}{*}{$\begin{array}{c}\text { Tipo de } \\
\text { Recobrimento }\end{array}$} & \multicolumn{4}{|c|}{ Período de Armazenamento (dias) } \\
\hline & 30 & 60 & 90 & 120 \\
\hline $\mathrm{FE} / \mathrm{R}$ & $2,07^{\mathrm{ABCD}}$ & $1,18^{\mathrm{BCDEFG}}$ & $0,22^{E F G}$ & $0,00^{\mathrm{G}}$ \\
\hline $\mathrm{PV} / \mathrm{R}$ & $2,05^{A B C D}$ & $2,24 \mathrm{ABCD}$ & 1,71 BCDEFG & $1,12^{\mathrm{CDEFG}}$ \\
\hline $\mathrm{PA} / \mathrm{R}$ & $1,28^{\mathrm{BCDEFG}}$ & $2,13^{A B C D}$ & $1,51^{\mathrm{BCDEFG}}$ & $0,00^{\mathrm{G}}$ \\
\hline SP/R & $2,90^{A B}$ & $1,08^{C D E F G}$ & $2,53^{\mathrm{ABC}}$ & $0,65^{\mathrm{DEFG}}$ \\
\hline $\mathrm{SR} / \mathrm{R}$ & $1,86^{\mathrm{BCDE}}$ & 1,11 CDEFG & $0,10^{\mathrm{FG}}$ & $0,00^{\mathrm{G}}$ \\
\hline $\mathrm{FE} / \mathrm{A}$ & $1,11^{\mathrm{CDEFG}}$ & $0,00^{\mathrm{G}}$ & $0,00^{\mathrm{G}}$ & $0,00^{\mathrm{G}}$ \\
\hline $\mathrm{PV} / \mathrm{A}$ & $1,00^{\mathrm{CDEFG}}$ & $1,78^{B C D E F}$ & $1,55^{\mathrm{BCDEFG}}$ & $0,71^{\mathrm{DEFG}}$ \\
\hline $\mathrm{PA} / \mathrm{A}$ & $1,77^{\mathrm{BCDEF}}$ & $0,15 \mathrm{EFG}$ & $0,01^{\mathrm{G}}$ & $0,00^{G}$ \\
\hline $\mathrm{SP} / \mathrm{A}$ & $3,60^{\mathrm{A}}$ & $0,88^{\mathrm{CDEFG}}$ & $1,18^{\mathrm{BCDEFG}}$ & $0,12^{\mathrm{EFG}}$ \\
\hline $\mathrm{SR} / \mathrm{A}$ & $1,14^{\mathrm{CDEFG}}$ & $0,00^{\mathrm{G}}$ & $0,00^{\mathrm{G}}$ & $0,00^{\mathrm{G}}$ \\
\hline $\mathrm{TT}^{*}$ & $0,51^{\mathrm{DEFG}}$ & - & - & - \\
\hline
\end{tabular}

A Tabela 6, de média da massa de matéria fresca de raízes mostra que TT obteve um resultado de $0,51 \mathrm{~g}$, sendo superado estatisticamente por alguns tratamentos. O melhor resultado observado foi para SP/A com 30 dias de armazenamento $(3,60 \mathrm{~g})$, seguido por SP/R, com 2,90g.

Aos 60 dias, nenhum tratamento foi melhor estatisticamente que TT.

Aos 90 dias, como se pode observar, o melhor resultado foi obtido no tratamento SP/R, com valor de $2,53 \mathrm{~g}$, diferindo estatisticamente de TT.

Para 120 dias, novamente nenhum tratamento diferiu estatisticamente da testemunha.

Seguindo a Tabela 9, pode-se perceber que os dados da Tabela 8 se confirmam, onde SP/R e SP/A se destacam como os melhores tratamentos para se obter bons resultados de enraizamento.

$\mathrm{Na}$ Tabela 7 podem ser observados as médias de massa de matéria seca de raízes, aos $30,60,90$ ou 120 dias de armazenamento em condições de temperatura ambiente ou refrigerada para estacas de primavera de C. rubra para os diferentes tipos de recobrimento, mais a testemunha.

Observando a Tabela 7, de média de massa de matéria seca de raízes, verifica-se que até 30 dias de armazenamento, todos os tratamentos tiveram valores absolutos maiores que o tratamento testemunha TT $(0,05 \mathrm{~g})$, sendo que os resultados que diferiram estatisticamente foram SP/R $(0,52 \mathrm{~g})$ e SP/A $(0,55 \mathrm{~g})$. 
Tabela 7. Médias das massas de matéria seca de raízes, em gramas, desenvolvidas em estacas de primavera de C. rubra, armazenadas por 30, 60, 90 ou 120 dias, em condições de temperatura ambiente ou refrigerada e submetidas aos diferentes tipos de recobrimento

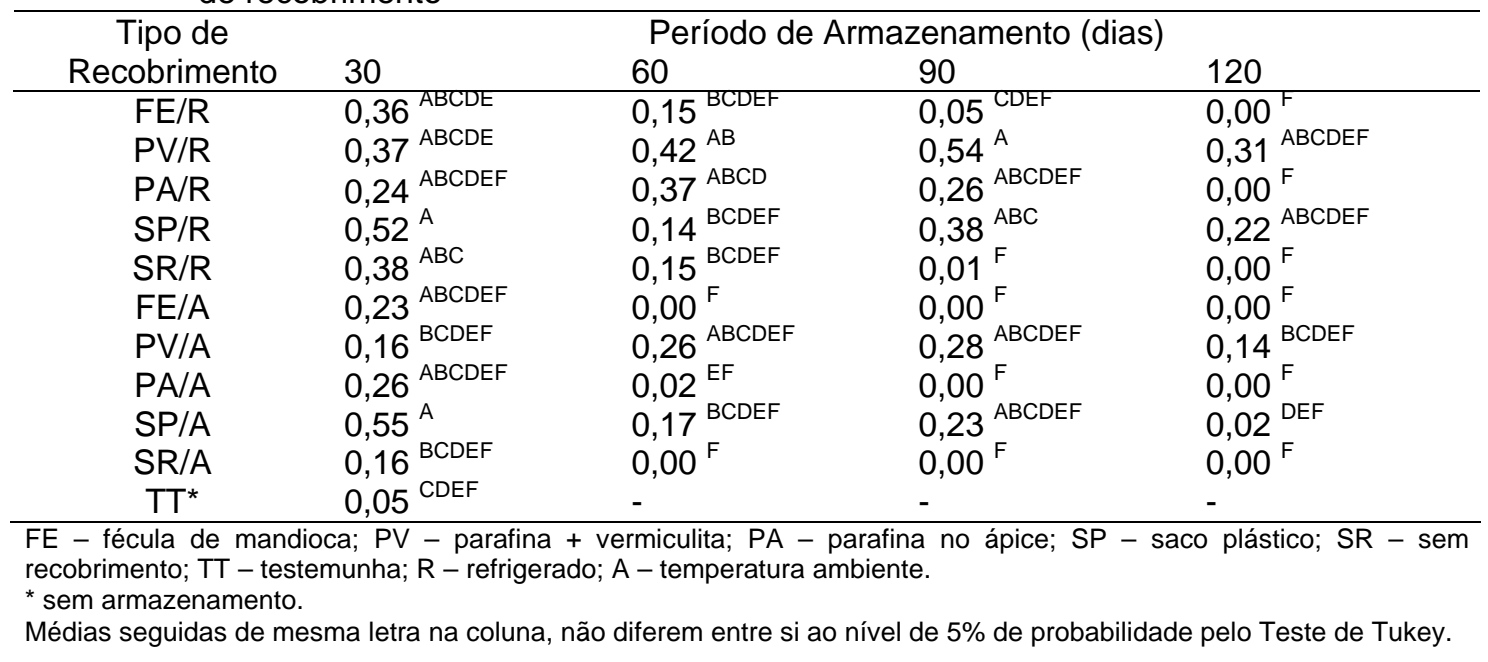

Aos 60 dias de armazenamento, apenas o tratamento PV/R $(0,42 \mathrm{~g})$ diferiu estatisticamente do tratamento testemunha.

Até 90 dias de armazenamento, novamente PV/R mostrou um dos melhores resultados, com $0,54 \mathrm{~g}$, sendo melhor estatisticamente que TT.

Aos 120 dias de armazenamento nenhum dos resultados observados diferiu estatisticamente de TT.

A Tabela 8 mostram as médias do número de rizomas observados aos 30, 60, 90 ou 120 dias de armazenamento em condições de temperatura ambiente ou refrigerada para estacas de primavera de C. rubra para os diferentes tipos de recobrimento, mais a testemunha.

De acordo com esta Tabela, de média do número de rizomas desenvolvidos, pode-se observar que o tratamento testemunha não apresentou desenvolvimento de rizomas.

Os melhores resultados observados foram para 30 dias em SP/A $(1,00)$ e SP/R $(0,93)$ e $\mathrm{PA} / \mathrm{A}(0,80)$, que juntamente com $\mathrm{SP} / \mathrm{R}$ aos 90 dias $(0,93)$, não diferiram estatisticamente entre si, sendo melhores do que o tratamento testemunha.

Pode-se notar que conforme o período de armazenamento aumenta, o número de rizomas diminui consideravelmente. Pôde-se notar, durante as avaliações, que estacas mais vigorosas emitiam rizomas de maior calibre e maior comprimento, o que significa que quanto melhores forem as condições de armazenamento, maiores as chances de produzirmos plantas com melhor qualidade. 
Tabela 8. Médias dos números de rizomas desenvolvidos em estacas de primavera de $C$. rubra, armazenadas por 30,60, 90 ou 120 dias, em condições de temperatura ambiente ou refrigerada e submetidas aos diferentes tipos de recobrimento

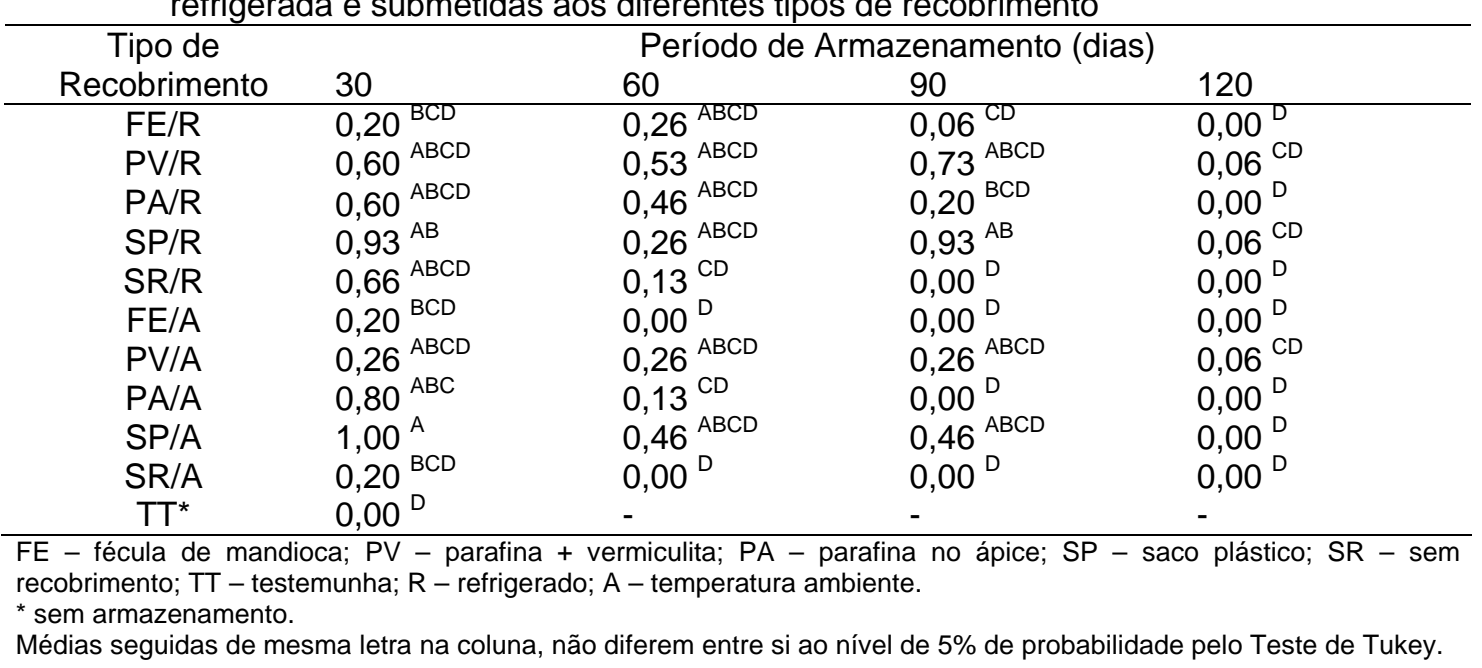

A Tabela 9 mostra as médias das massas de matéria fresca de rizomas (em gramas) observados após 30,60, 90 ou 120 dias de armazenamento em condições de temperatura ambiente ou refrigerada para estacas de primavera de $C$. rubra para os diferentes tipos de recobrimento, mais a testemunha.

Tabela 9. Médias das massas de matéria fresca de rizomas, em gramas, desenvolvidos em estacas de primavera de C. rubra, armazenadas por 30, 60, 90 ou 120 dias, em condições de temperatura ambiente ou refrigerada e submetidas aos diferentes tipos de recobrimento

\begin{tabular}{cllll}
\hline $\begin{array}{c}\text { Tipo de } \\
\text { Recobrimento }\end{array}$ & 30 & \multicolumn{3}{c}{ Período de Armazenamento (dias) } \\
\hline FE/R & $0,13^{\mathrm{BC}}$ & 60 & 90 & 120 \\
$\mathrm{PV} / \mathrm{R}$ & $0,57^{\mathrm{ABC}}$ & $0,31^{\mathrm{ABC}}$ & $0,01^{\mathrm{C}}$ & $0,00^{\mathrm{C}}$ \\
$\mathrm{PA} / \mathrm{R}$ & $0,42^{\mathrm{ABC}}$ & $0,38^{\mathrm{ABC}}$ & $0,72^{\mathrm{ABC}}$ & $0,05^{\mathrm{BC}}$ \\
$\mathrm{SP} / \mathrm{R}$ & $0,49^{\mathrm{ABC}}$ & $0,24^{\mathrm{ABC}}$ & $0,36^{\mathrm{ABC}}$ & $0,00^{\mathrm{C}}$ \\
$\mathrm{SR} / \mathrm{R}$ & $0,49^{\mathrm{ABC}}$ & $0,10^{\mathrm{BC}}$ & $0,90^{\mathrm{A}}$ & $0,06^{\mathrm{BC}}$ \\
$\mathrm{FE} / \mathrm{A}$ & $0,24^{\mathrm{ABC}}$ & $0,08^{\mathrm{BC}}$ & $0,00^{\mathrm{C}}$ & $0,00^{\mathrm{C}}$ \\
$\mathrm{PV} / \mathrm{A}$ & $0,18^{\mathrm{ABC}}$ & $0,00^{\mathrm{C}}$ & $0,00^{\mathrm{C}}$ & $0,00^{\mathrm{C}}$ \\
$\mathrm{PA} / \mathrm{A}$ & $0,55^{\mathrm{ABC}}$ & $0,30^{\mathrm{ABC}}$ & $0,15^{\mathrm{ABC}}$ & $0,06^{\mathrm{BC}}$ \\
$\mathrm{SP} / \mathrm{A}$ & $0,79^{\mathrm{AB}}$ & $0,11^{\mathrm{BC}}$ & $0,00^{\mathrm{C}}$ & $0,00^{\mathrm{C}}$ \\
SR/A & $0,12^{\mathrm{BC}}$ & $0,11^{\mathrm{BC}}$ & $0,23^{\mathrm{ABC}}$ & $0,00^{\mathrm{C}}$ \\
TT* & $0,00^{\mathrm{C}}$ & $-0^{\mathrm{C}}$ & $0,00^{\mathrm{C}}$ & $0,00^{\mathrm{C}}$ \\
\hline FE - fécula de mandioca; $\mathrm{PV}-$ parafina + vermiculita; PA - parafina no ápice; SP - saco plástico; SR - sem \\
recobrimento; TT - testemunha; R - refrigerado; A - temperatura ambiente. \\
* sem armazenamento. \\
Médias seguidas de mesma letra na coluna, não diferem entre si ao nível de 5\% de probabilidade pelo Teste de Tukey.
\end{tabular}

Pela Tabela 9, de média de massa de matéria fresca de rizomas, o melhor resultado foi observado aos 90 dias de armazenamento para o tratamento SP/R com $0,90 \mathrm{~g}$, sendo que o 
tratamento testemunha, como já foi dito, não apresentou desenvolvimento de rizomas, sendo então de valor zero.

Aos 30 dias, o melhor valor observado foi para SP/R com $0,79 \mathrm{~g}$, não diferindo do mesmo tratamento para 90 dias de armazenamento. Os demais tratamentos não foram significativos.

A Tabela 10 mostra as médias das massas de matéria seca de rizomas (em gramas) observados aos 30, 60, 90 ou 120 dias de armazenamento em condições de temperatura ambiente ou refrigerada para estacas de primavera de C. rubra para os diferentes tipos de recobrimento, mais a testemunha.

Tabela 10. Médias das massas de matéria seca de rizomas, em gramas, desenvolvidos em estacas de primavera de C. rubra, armazenadas por 30, 60, 90 ou 120 dias, em condições de temperatura ambiente ou refrigerada e submetidas aos diferentes tipos de recobrimento

\begin{tabular}{|c|c|c|c|c|}
\hline Tipo de & \multicolumn{4}{|c|}{ Período de Armazenamento (dias) } \\
\hline Recobrimento & 30 & 60 & 90 & 120 \\
\hline $\mathrm{FE} / \mathrm{R}$ & $0,01^{\mathrm{BC}}$ & $0,03^{A B C}$ & $0,00^{\mathrm{C}}$ & $0,00^{\mathrm{C}}$ \\
\hline$P V / R$ & $0,05^{\mathrm{ABC}}$ & $0,03^{A B C}$ & $0,08^{A B}$ & $0,00^{\mathrm{BC}}$ \\
\hline $\mathrm{PA} / \mathrm{R}$ & $0,05^{\mathrm{ABC}}$ & $0,02^{A B C}$ & $0,03^{\mathrm{ABC}}$ & $0,00^{\mathrm{C}}$ \\
\hline $\mathrm{SP} / \mathrm{R}$ & $0,05^{\mathrm{ABC}}$ & $0,01^{\mathrm{BC}}$ & $0,09^{A}$ & $0,00^{\mathrm{BC}}$ \\
\hline $\mathrm{SR} / \mathrm{R}$ & $0,04^{\mathrm{ABC}}$ & $0,00^{\mathrm{BC}}$ & $0,00^{\mathrm{C}}$ & $0,00^{\mathrm{C}}$ \\
\hline $\mathrm{FE} / \mathrm{A}$ & $0,02^{\mathrm{ABC}}$ & $0,00^{\mathrm{C}}$ & $0,00^{\mathrm{C}}$ & $0,00^{\mathrm{C}}$ \\
\hline PV/A & $0,01^{\mathrm{ABC}}$ & $0,03^{A B C}$ & $0,01^{A B C}$ & $0,00^{\mathrm{BC}}$ \\
\hline $\mathrm{PA} / \mathrm{A}$ & $0,05^{\mathrm{ABC}}$ & $0,01^{\mathrm{BC}}$ & $0,00^{\mathrm{C}}$ & $0,00^{\mathrm{C}}$ \\
\hline SP/A & $0,07^{\mathrm{ABC}}$ & $0,01^{\mathrm{BC}}$ & $0,03^{\mathrm{ABC}}$ & $0,00^{\mathrm{C}}$ \\
\hline SR/A & $0,01^{\mathrm{BC}}$ & $0,00^{\mathrm{C}}$ & $0,00^{\mathrm{C}}$ & $0,00^{\mathrm{C}}$ \\
\hline $\mathrm{TT}^{*}$ & $0,00^{\mathrm{C}}$ & - & - & - \\
\hline
\end{tabular}

De acordo com a Tabela 10, de média de massa de matéria seca de rizomas, mais uma vez, o melhor resultado foi com SP/R $(0,09 \mathrm{~g})$ aos 90 dias, seguido de PV/R $(0,08 \mathrm{~g})$, também para 90 dias, onde os dois tratamentos não diferiram estatisticamente entre si. Estes valores confirmam os resultados obtidos para as tabelas anteriores, tanto de número de rizomas, quanto de massa de matéria fresca dos mesmos.

\section{1. 3 Relação entre condições e períodos de armazenamento.}

As Tabelas 11, 12 e 13 demonstram as análises das médias de número, de brotos, raízes e rizomas respectivamente desenvolvidos nas estacas de $C$. rubra, além da massa de 
matéria fresca e seca dos mesmos, relacionados com os períodos (30, 60, 90 ou 120 dias) e às condições de armazenamento (temperatura ambiente ou sob refrigeração).

Tabela 11. Médias do número de brotos desenvolvidos e suas respectivas massas de matéria fresca e seca, em gramas, em estacas de primavera de C. rubra, armazenadas por $30,60,90$ ou 120 dias, em condições de temperatura ambiente ou sob refrigeração

\begin{tabular}{|c|c|c|c|}
\hline \multirow[b]{2}{*}{ Parâmetros } & \multirow{2}{*}{$\begin{array}{c}\text { Período de } \\
\text { Armazenamento } \\
\text { (dias) }\end{array}$} & \multicolumn{2}{|c|}{ Condição de Armazenamento } \\
\hline & & $\begin{array}{c}\text { Ambiente } \\
\text { Refrigerado }\end{array}$ & $\begin{array}{c}\text { Temperatura } \\
\text { Ambiente }\end{array}$ \\
\hline Número de Brotos & $\begin{array}{c}30 \\
60 \\
90 \\
120\end{array}$ & $\begin{array}{c}3,93 \mathrm{aA} \\
3,18 \mathrm{abA} \\
2,68 \mathrm{bA} \\
1,20 \mathrm{cA}\end{array}$ & $\begin{array}{l}3,09 \mathrm{aA} \\
1,16 \mathrm{bB} \\
0,92 \mathrm{bB} \\
0,45 \mathrm{bA}\end{array}$ \\
\hline $\begin{array}{c}\text { Massa de Matéria } \\
\text { Fresca } \\
\text { (g) }\end{array}$ & $\begin{array}{c}30 \\
60 \\
90 \\
120\end{array}$ & $\begin{array}{c}10,55 \mathrm{aA} \\
7,51 \mathrm{bA} \\
4,27 \mathrm{cA} \\
2,30 \mathrm{cA}\end{array}$ & $\begin{array}{l}6,63 \mathrm{aB} \\
2,51 \mathrm{bB} \\
2,03 \mathrm{bA} \\
0,65 \mathrm{bA}\end{array}$ \\
\hline $\begin{array}{c}\text { Massa de Matéria } \\
\text { Seca } \\
(\mathrm{g})\end{array}$ & $\begin{array}{c}30 \\
60 \\
90 \\
120\end{array}$ & $\begin{array}{l}1,97 \mathrm{aA} \\
1,25 \mathrm{bA} \\
0,78 \mathrm{cA} \\
0,42 \mathrm{cA}\end{array}$ & $\begin{array}{l}1,17 \mathrm{aB} \\
0,45 \mathrm{bB} \\
0,39 \mathrm{bA} \\
0,12 \mathrm{bA}\end{array}$ \\
\hline
\end{tabular}

Médias seguidas de mesma letra (letras minúsculas na vertical; letras maiúsculas na horizontal, para cada item), não diferem entre si ao nível de $5 \%$ de probabilidade pelo Teste de Tukey.

Pode-se observar na Tabela 11, que os melhores resultados obtidos foram nos menores períodos de armazenamento e com o aumento dos períodos, a tendência foi ocorrer diminuição no número de brotos desenvolvidos. Em ambiente refrigerado, por exemplo, aos 30 e 60 dias de armazenamento, não houveram diferenças no desenvolvimento de brotos, com 3,93 e 3,18 brotos respectivamente. Apesar de aos 30 dias de armazenamento não haver ocorrido diferenças significativas entre as duas condições de armazenamento, de um modo geral, com aumento do período de armazenamento, a tendência observada em estacas armazenadas em ambiente refrigerado foi de desenvolver maior número de brotos em relação às estacas mantidas em temperatura ambiente.

São mostradas também as médias de matéria fresca de brotos e pode-se observar que os únicos resultados que se destacaram foram os para 30 dias de armazenamento, não importando a condição de armazenamento, sendo que para períodos maiores, a tendência foi de médias serem cada vez menores. Na comparação entre estacas armazenadas em temperatura ambiente e sob refrigeração, os tratamentos que foram mantidos em ambiente refrigerado foram estatisticamente iguais ou melhores que as estacas mantidas em temperatura ambiente em todos os períodos.

Com as médias de matérias secas de brotos, relacionadas com os períodos de armazenamento e as condições de armazenamento e pode-se obter a confirmação de que a 
massa de matéria seca de brotos é inversamente proporcional ao período de armazenamento das estacas. As estacas armazenadas por 30 dias em ambas as condições de armazenamento se destacaram em relação aos demais períodos, com 1,97g para ambiente refrigerado e $1,17 \mathrm{~g}$ para temperatura ambiente. Para 30 e 60 dias, as estacas armazenadas em ambiente refrigerado foram estatisticamente melhores que as estacas mantidas em temperatura ambiente, enquanto que, para 90 ou 120 dias não houveram diferenças significativas.

Tabela 12. Médias do número de raízes desenvolvidas e suas respectivas massas de matéria fresca e seca, em gramas, em estacas de primavera de C. rubra, armazenadas por $30,60,90$ ou 120 dias, em condições de temperatura ambiente ou sob refrigeração

\begin{tabular}{cccc}
\hline Parâmetros & $\begin{array}{c}\text { Período de } \\
\text { Armazenamento } \\
\text { (dias) }\end{array}$ & $\begin{array}{c}\text { Condição de Armazenamento } \\
\text { Ambiente } \\
\text { Refrigerado }\end{array}$ & $\begin{array}{c}\text { Temperatura } \\
\text { Ambiente }\end{array}$ \\
\hline Número de Raízes & 30 & $9,57 \mathrm{aA}$ & $9,76 \mathrm{aA}$ \\
& 60 & $7,05 \mathrm{abA}$ & $3,70 \mathrm{bB}$ \\
& 90 & $5,97 \mathrm{bA}$ & $4,16 \mathrm{bA}$ \\
Massa de Matéria & 120 & $2,54 \mathrm{cA}$ & $0,77 \mathrm{cA}$ \\
Fresca & 30 & $2,03 \mathrm{aA}$ & $1,72 \mathrm{aA}$ \\
(g) & 60 & $1,55 \mathrm{abA}$ & $0,56 \mathrm{bB}$ \\
& 90 & $1,22 \mathrm{bA}$ & $0,54 \mathrm{bB}$ \\
Massa de Matéria & 120 & $0,35 \mathrm{cA}$ & $0,16 \mathrm{bA}$ \\
Seca & 30 & $0,38 \mathrm{aA}$ & $0,27 \mathrm{aA}$ \\
(g) & 60 & $0,25 \mathrm{bA}$ & $0,09 \mathrm{bB}$ \\
& 90 & $0,25 \mathrm{bA}$ & $0,10 \mathrm{bB}$ \\
& 120 & $0,10 \mathrm{cA}$ & $0,03 \mathrm{bA}$ \\
\hline
\end{tabular}

Médias seguidas de mesma letra (letras minúsculas na vertical; letras maiúsculas na horizontal, para cada item), não diferem entre si ao nível de $5 \%$ de probabilidade pelo Teste de Tukey.

$\mathrm{Na}$ Tabela 12, verifica se que o ambiente refrigerado em conjunto com os menores períodos de armazenamento apresentaram os melhores resultados para o desenvolvimento de raízes, como é mostrado através dos valores de massa de matéria fresca em 30 dias de armazenamento tanto em ambiente refrigerado $(2,03 \mathrm{~g})$ como para temperatura ambiente $(1,72 \mathrm{~g})$. E esses dados podem ser confirmados através dos valores de massa de matéria seca das mesmas raízes. Pode-se observar que o fator período de armazenamento influi diretamente no desenvolvimento de raízes das estacas e que afeta ambas as condições de armazenamento. 
Tabela 13. Médias do número de rizomas desenvolvidos e suas respectivas massas de matéria fresca e seca, em gramas, em estacas de primavera de C. rubra, armazenadas por 30, 60, 90 ou 120 dias, em condições de temperatura ambiente ou sob refrigeração

\begin{tabular}{|c|c|c|c|}
\hline \multirow[b]{2}{*}{ Parâmetros } & \multirow{2}{*}{$\begin{array}{l}\text { Período de } \\
\text { Armazenamento } \\
\text { (dias) }\end{array}$} & \multicolumn{2}{|c|}{ Condição de Armazenamento } \\
\hline & & $\begin{array}{l}\text { Ambiente } \\
\text { Refrigerado }\end{array}$ & $\begin{array}{l}\text { Temperatura } \\
\text { Ambiente }\end{array}$ \\
\hline Número de rizomas & $\begin{array}{c}30 \\
60 \\
90 \\
120\end{array}$ & $\begin{array}{c}0,60 \mathrm{aA} \\
0,33 \mathrm{bA} \\
0,38 \mathrm{abA} \\
0,02 \mathrm{cA}\end{array}$ & $\begin{array}{l}0,49 \mathrm{aA} \\
0,17 \mathrm{bA} \\
0,14 \mathrm{bA} \\
0,01 \mathrm{bA}\end{array}$ \\
\hline $\begin{array}{c}\text { Massa de Matéria } \\
\text { Fresca } \\
(\mathrm{g})\end{array}$ & $\begin{array}{c}30 \\
60 \\
90 \\
120\end{array}$ & $\begin{array}{c}0,42 \mathrm{aA} \\
0,22 \mathrm{abA} \\
0,40 \mathrm{aA} \\
0,02 \mathrm{bA}\end{array}$ & $\begin{array}{l}0,38 \mathrm{aA} \\
0,10 \mathrm{bA} \\
0,07 \mathrm{bB} \\
0,01 \mathrm{bA}\end{array}$ \\
\hline $\begin{array}{c}\text { Massa de Matéria } \\
\text { Seca } \\
(\mathrm{g})\end{array}$ & $\begin{array}{c}30 \\
60 \\
90 \\
120\end{array}$ & $\begin{array}{c}0,04 \mathrm{aA} \\
0,02 \mathrm{abA} \\
0,04 \mathrm{aA} \\
0,00 \mathrm{bA}\end{array}$ & $\begin{array}{c}0,03 \mathrm{aA} \\
0,01 \mathrm{abA} \\
0,01 \mathrm{bB} \\
0,00 \mathrm{bA}\end{array}$ \\
\hline
\end{tabular}

Médias seguidas de mesma letra (letras minúsculas na vertical; letras maiúsculas na horizontal, para cada item), não diferem entre si ao nível de $5 \%$ de probabilidade pelo Teste de Tukey.

$\mathrm{Na}$ Tabela 13, pode-se verificar que aos 30 e 90 dias de armazenamento, em ambiente refrigerado, as formações de rizomas foram superiores em relação às estacas mantidas em armazenamento por 60 e 120 dias. Quanto às estacas mantidas em temperatura ambiente, as que apresentaram maior número de rizomas formados foi em 30 dias de armazenamento.

Ao relacionar as condições de armazenamento, constatou-se que foram pequenas as diferenças quanto à formação de rizomas.

\section{1. 4 Relação entre condições de armazenamento e tipos de recobrimento}

As Tabelas 14, 15 e 16 apresentam as análises das médias de número, de brotos, raízes e rizomas respectivamente, desenvolvidos em estacas de $C$. rubra, além da massa de matéria fresca e seca dos mesmos, relacionados com as condições de armazenamento (temperatura ambiente e sob refrigeração) e os tipos de recobrimento (FE, PV, PA, SP e SR). 
Tabela 14. Médias do número de brotos desenvolvidos e suas respectivas massas de matéria fresca e seca, em gramas, observados em estacas de primavera de C. rubra, tratadas com 5 tipos de recobrimento e armazenadas em condições de temperatura ambiente ou sob refrigeração

\begin{tabular}{|c|c|c|c|}
\hline \multirow[b]{2}{*}{ Parâmetros } & \multirow[b]{2}{*}{$\begin{array}{c}\text { Tipo de } \\
\text { Recobrimento }\end{array}$} & \multicolumn{2}{|c|}{ Condição de Armazenamento } \\
\hline & & $\begin{array}{l}\text { Ambiente } \\
\text { Refrigerado }\end{array}$ & $\begin{array}{l}\text { Temperatura } \\
\text { Ambiente }\end{array}$ \\
\hline Número de Brotos & $\begin{array}{l}\text { FE } \\
\text { PV } \\
\text { PA } \\
\text { SP } \\
\text { SR }\end{array}$ & $\begin{array}{l}1,63 \mathrm{cA} \\
3,88 \mathrm{aA} \\
2,63 \mathrm{bA} \\
3,36 \mathrm{abA} \\
2,23 \mathrm{bcA}\end{array}$ & $\begin{array}{l}0,70 \mathrm{bA} \\
2,26 \mathrm{aB} \\
1,01 \mathrm{bB} \\
2,30 \mathrm{aB} \\
0,75 \mathrm{bB}\end{array}$ \\
\hline $\begin{array}{l}\text { Massa de Matéria Fresca } \\
\qquad(\mathrm{g})\end{array}$ & $\begin{array}{l}\text { FE } \\
\text { PV } \\
\text { PA } \\
\text { SP } \\
\text { SR }\end{array}$ & $\begin{array}{l}3,65 \mathrm{bA} \\
8,78 \mathrm{aA} \\
5,89 \mathrm{bA} \\
8,78 \mathrm{aA} \\
3,69 \mathrm{bA}\end{array}$ & $\begin{array}{l}1,21 \mathrm{bA} \\
4,80 \mathrm{aB} \\
1,96 \mathrm{bB} \\
5,82 \mathrm{aB} \\
0,99 \mathrm{bA}\end{array}$ \\
\hline $\begin{array}{l}\text { Massa de Matéria Seca } \\
\qquad(\mathrm{g})\end{array}$ & $\begin{array}{l}\text { FE } \\
\text { PV } \\
\text { PA } \\
\text { SP } \\
\text { SR }\end{array}$ & $\begin{array}{l}0,62 \mathrm{bA} \\
1,57 \mathrm{aA} \\
1,04 \mathrm{bA} \\
1,67 \mathrm{aA} \\
0,63 \mathrm{bA}\end{array}$ & $\begin{array}{l}0,19 \mathrm{bA} \\
0,90 \mathrm{aB} \\
0,35 \mathrm{bB} \\
1,09 \mathrm{aB} \\
0,15 \mathrm{bA}\end{array}$ \\
\hline
\end{tabular}
recobrimento.

Médias seguidas de mesma letra (letras minúsculas na vertical; letras maiúsculas na horizontal, para cada item), não diferem entre si ao nível de $5 \%$ de probabilidade pelo Teste de Tukey.

Tabela 15. Médias do número de raízes desenvolvidas e suas respectivas massas de matéria fresca e seca, em gramas, observadas em estacas de primavera de C. rubra, tratadas com 5 tipos de recobrimento e armazenadas em condições de temperatura ambiente ou sob refrigeração

\begin{tabular}{|c|c|c|c|}
\hline \multirow[b]{2}{*}{ Parâmetros } & & \multicolumn{2}{|c|}{ Condição de Armazenamento } \\
\hline & $\begin{array}{l}\text { Tipo de } \\
\text { Renbrimento }\end{array}$ & Ambiente & $\begin{array}{l}\text { Temperatura } \\
\text { Ambiente }\end{array}$ \\
\hline Número de Raízes & $\begin{array}{l}\text { FE } \\
\text { PV } \\
\text { PA } \\
\text { SP } \\
\text { SR }\end{array}$ & $\begin{array}{c}4,31 \mathrm{bA} \\
9,11 \mathrm{aA} \\
6,11 \mathrm{abA} \\
7,46 \mathrm{abA} \\
4,41 \mathrm{bA}\end{array}$ & $\begin{array}{l}1,91 \mathrm{bA} \\
8,58 \mathrm{aA} \\
2,90 \mathrm{bA} \\
7,16 \mathrm{aA} \\
2,43 \mathrm{bA}\end{array}$ \\
\hline $\begin{array}{l}\text { Massa de Matéria Fresca } \\
\qquad(\mathrm{g})\end{array}$ & $\begin{array}{l}\text { FE } \\
\text { PV } \\
\text { PA } \\
\text { SP } \\
\text { SR }\end{array}$ & $\begin{array}{c}0,87 \mathrm{bA} \\
1,78 \mathrm{aA} \\
1,23 \mathrm{abA} \\
1,79 \mathrm{aA} \\
0,77 \mathrm{bA}\end{array}$ & $\begin{array}{l}0,27 \mathrm{bA} \\
1,26 \mathrm{aA} \\
0,48 \mathrm{bA} \\
1,45 \mathrm{aA} \\
0,28 \mathrm{bA}\end{array}$ \\
\hline $\begin{array}{c}\text { Massa de Matéria Seca } \\
\qquad(\mathrm{g})\end{array}$ & $\begin{array}{l}\text { FE } \\
\text { PV } \\
\text { PA } \\
\text { SP } \\
\text { SR }\end{array}$ & $\begin{array}{l}0,14 \mathrm{bA} \\
0,41 \mathrm{aA} \\
0,22 \mathrm{bA} \\
0,32 \mathrm{aA} \\
0,13 \mathrm{bA}\end{array}$ & $\begin{array}{c}0,05 \mathrm{cA} \\
0,21 \mathrm{abA} \\
0,07 \mathrm{bB} \\
0,24 \mathrm{aA} \\
0,04 \mathrm{cA}\end{array}$ \\
\hline
\end{tabular}

FE - fécula de mandioca; PV - parafina + vermiculita; PA - parafina no ápice; SP - saco plástico; SR - sem recobrimento. Médias seguidas de mesma letra (letras minúsculas na vertical; letras maiúsculas na horizontal, para cada item), não diferem entre si ao nível de $5 \%$ de probabilidade pelo Teste de Tukey. 
Tabela 16. Médias do número de rizomas desenvolvidos e suas respectivas massas de matéria fresca e seca, em gramas, em estacas de primavera de C. rubra, tratadas com 5 tipos de recobrimento e armazenadas em condições de temperatura ambiente ou sob refrigeração

\begin{tabular}{cccc} 
sob refrigeração & \multicolumn{4}{c}{$\begin{array}{c}\text { Condição de Armazenamento } \\
\text { Parâmetros }\end{array}$} & $\begin{array}{c}\text { Tipo de } \\
\text { Ambiente } \\
\text { Refrigerado }\end{array}$ & $\begin{array}{c}\text { Temperatura } \\
\text { Ambiente }\end{array}$ \\
\hline Recobrimento & FE & $0,13 \mathrm{cA}$ & $0,05 \mathrm{bA}$ \\
& $\mathrm{PV}$ & $0,48 \mathrm{abA}$ & $0,21 \mathrm{abA}$ \\
& $\mathrm{PA}$ & $0,31 \mathrm{abcA}$ & $0,23 \mathrm{aA}$ \\
& $\mathrm{SP}$ & $0,55 \mathrm{aA}$ & $0,48 \mathrm{aA}$ \\
Massa de Matéria Fresca & $\mathrm{SR}$ & $0,20 \mathrm{bcA}$ & $0,05 \mathrm{bA}$ \\
& $\mathrm{FE}$ & $0,11 \mathrm{bA}$ & $0,06 \mathrm{aA}$ \\
& $\mathrm{PV}$ & $0,43 \mathrm{aA}$ & $0,17 \mathrm{aA}$ \\
& $\mathrm{PA}$ & $0,25 \mathrm{abA}$ & $0,16 \mathrm{aA}$ \\
Massa de Matéria Seca & $\mathrm{SP}$ & $0,39 \mathrm{abA}$ & $0,28 \mathrm{aA}$ \\
& $\mathrm{SR}$ & $0,14 \mathrm{abA}$ & $0,03 \mathrm{aA}$ \\
& $\mathrm{FE}$ & $0,01 \mathrm{bA}$ & $0,00 \mathrm{aA}$ \\
& $\mathrm{PV}$ & $0,04 \mathrm{aA}$ & $0,02 \mathrm{aA}$ \\
& $\mathrm{PA}$ & $0,02 \mathrm{abA}$ & $0,01 \mathrm{aA}$ \\
& $\mathrm{SP}$ & $0,04 \mathrm{abA}$ & $0,03 \mathrm{aA}$ \\
& $\mathrm{SR}$ & $0,01 \mathrm{abA}$ & $0,00 \mathrm{aA}$ \\
\hline
\end{tabular}

FE - fécula de mandioca; PV - parafina + vermiculita; PA - parafina no ápice; SP - saco plástico; SR - sem recobrimento.

Médias seguidas de mesma letra (letras minúsculas na vertical; letras maiúsculas na horizontal, para cada item), não diferem entre si ao nível de $5 \%$ de probabilidade pelo Teste de Tukey.

De acordo com as Tabelas 14, 15 e 16, pode se dizer que quando relacionados os fatores condição de armazenamento e tipo de recobrimento, verifica-se que o ambiente de armazenamento tem grande influência sobre a durabilidade das estacas, está intimamente relacionado com o vigor das mesmas. Não importando o tipo de recobrimento empregado, a conservação das estacas em ambiente refrigerado fez com que os valores das médias avaliadas fossem sempre superiores que as médias das estacas armazenadas mantidas em temperatura ambiente.

\section{1. 5 Relação entre tipos de recobrimento e períodos de armazenamento}

As Tabelas 17, 18 e 19 apresentam as análises das médias do número, de brotos, raízes e rizomas respectivamente, observados em estacas de $C$. rubra, além das massas de matéria fresca e seca dos mesmos, relacionados com os períodos de armazenamento $(30,60$, 90 ou 120 dias) e os tipos de recobrimento (FE, PV, PA, SP e SR). 
Tabela 17. Médias do número de brotos desenvolvidos e suas respectivas massas de matéria fresca e seca, em gramas, observadas em estacas de primavera de C. rubra, tratadas com 5 tipos de recobrimento e armazenadas por 30,60, 90 ou 120 dias

\begin{tabular}{|c|c|c|c|c|c|}
\hline \multirow[b]{2}{*}{ Parâmetros } & \multirow{2}{*}{$\begin{array}{c}\text { Tipo de } \\
\text { Recobrimento }\end{array}$} & \multicolumn{4}{|c|}{ Período de Armazenamento (dias) } \\
\hline & & 30 & 60 & 90 & 120 \\
\hline \multirow{5}{*}{ Número de Brotos } & $\mathrm{FE}$ & $2,93 \mathrm{bcC}$ & $0,96 \mathrm{bcC}$ & $0,76 \mathrm{cC}$ & $0,00 \mathrm{cB}$ \\
\hline & PV & 3,26 aA & $3,50 \mathrm{aA}$ & 3,03 aAB & $2,50 \mathrm{aA}$ \\
\hline & PA & 3,50 aA & $2,30 a b A B$ & $1,46 \mathrm{bcBC}$ & $0,03 \mathrm{cB}$ \\
\hline & SP & $3,90 \mathrm{aA}$ & $2,66 \mathrm{abAB}$ & $3,16 a b A$ & $1,60 \mathrm{bAB}$ \\
\hline & SR & 3,96 aA & $1,43 \mathrm{bBC}$ & $0,56 \mathrm{bC}$ & $0,00 \mathrm{bB}$ \\
\hline \multirow{5}{*}{$\begin{array}{l}\text { Massa de Matéria Fresca } \\
\qquad(\mathrm{g})\end{array}$} & FE & $7,48 \mathrm{aB}$ & $1,86 \mathrm{bB}$ & $0,38 \mathrm{bB}$ & $0,00 \mathrm{bA}$ \\
\hline & PV & $7,40 \mathrm{abB}$ & $9,53 \mathrm{aA}$ & $6,02 a b A$ & $4,20 \mathrm{bA}$ \\
\hline & PA & $8,04 \mathrm{aB}$ & $5,22 \mathrm{abAB}$ & $2,45 \mathrm{bcAB}$ & $0,01 \mathrm{cA}$ \\
\hline & SP & $12,96 \mathrm{aA}$ & $6,42 \mathrm{bA}$ & $6,63 \mathrm{bA}$ & $3,19 \mathrm{bA}$ \\
\hline & SR & $7,08 \mathrm{aB}$ & $2,02 \mathrm{bB}$ & $0,27 \mathrm{bB}$ & $0,00 \mathrm{bA}$ \\
\hline \multirow{5}{*}{$\begin{array}{l}\text { Massa de Matéria Seca } \\
\qquad(\mathrm{g})\end{array}$} & FE & $8,63 \mathrm{aA}$ & $2,36 \mathrm{bB}$ & $1,46 \mathrm{bC}$ & $0,00 \mathrm{bA}$ \\
\hline & PV & $9,30 \mathrm{abA}$ & $9,63 a b A$ & $11,06 \mathrm{aA}$ & $5,40 \mathrm{bA}$ \\
\hline & PA & $7,70 \mathrm{aA}$ & 5,96 aAB & $4,33 \mathrm{abBC}$ & $0,03 \mathrm{bA}$ \\
\hline & SP & $12,76 \mathrm{aA}$ & $5,70 \mathrm{bAB}$ & $7,93 \mathrm{abAB}$ & $2,86 \mathrm{bA}$ \\
\hline & SR & 9,93 aA & $3,23 \mathrm{bB}$ & $0,53 \mathrm{bC}$ & $0,00 \mathrm{bA}$ \\
\hline
\end{tabular}

Tabela 18. Médias do número de raízes desenvolvidas e suas respectivas massas de matéria fresca e seca, em gramas, observadas em estacas de primavera de C. rubra, tratadas com 5 tipos de recobrimento e armazenadas por 30, 60, 90 ou 120 dias

\begin{tabular}{cccccc}
\hline & Tipo de & \multicolumn{3}{c}{ Período de Armazenamento (dias) } \\
Parâmetros & Recobrimento & 30 & 60 & 90 & 120 \\
\hline Número de Raízes & $\mathrm{FE}$ & $8,63 \mathrm{aA}$ & $2,36 \mathrm{bB}$ & $1,46 \mathrm{bC}$ & $0,00 \mathrm{bA}$ \\
& $\mathrm{PV}$ & $9,30 \mathrm{abA}$ & $9,63 \mathrm{abA}$ & $11,06 \mathrm{aA}$ & $5,40 \mathrm{bA}$ \\
& $\mathrm{PA}$ & $7,70 \mathrm{aA}$ & $5,96 \mathrm{aAB}$ & $4,33 \mathrm{abBC}$ & $0,03 \mathrm{bA}$ \\
& $\mathrm{SP}$ & $12,76 \mathrm{aA}$ & $5,70 \mathrm{bAB}$ & $7,93 \mathrm{abAB}$ & $2,86 \mathrm{bA}$ \\
Massa de Matéria Fresca & $\mathrm{SR}$ & $9,93 \mathrm{aA}$ & $3,23 \mathrm{bB}$ & $0,53 \mathrm{bC}$ & $0,00 \mathrm{bA}$ \\
& $\mathrm{FE}$ & $1,59 \mathrm{aB}$ & $0,59 \mathrm{abB}$ & $0,11 \mathrm{bB}$ & $0,00 \mathrm{bA}$ \\
& $\mathrm{PV}$ & $1,52 \mathrm{aB}$ & $2,01 \mathrm{aA}$ & $1,63 \mathrm{aA}$ & $0,91 \mathrm{aA}$ \\
& $\mathrm{PA}$ & $1,52 \mathrm{aB}$ & $1,14 \mathrm{aAB}$ & $0,76 \mathrm{abAB}$ & $0,00 \mathrm{bA}$ \\
& $\mathrm{SP}$ & $3,25 \mathrm{aA}$ & $0,98 \mathrm{bcAB}$ & $1,86 \mathrm{bA}$ & $0,39 \mathrm{cA}$ \\
Massa de Matéria Seca & $\mathrm{SR}$ & $1,50 \mathrm{aB}$ & $0,55 \mathrm{abB}$ & $0,05 \mathrm{bB}$ & $0,00 \mathrm{bA}$ \\
& $\mathrm{FE}$ & $0,29 \mathrm{aB}$ & $0,07 \mathrm{abB}$ & $0,02 \mathrm{bCD}$ & $0,00 \mathrm{bA}$ \\
& $\mathrm{PV}$ & $0,27 \mathrm{aB}$ & $0,34 \mathrm{aA}$ & $0,41 \mathrm{aA}$ & $0,22 \mathrm{aA}$ \\
& $\mathrm{PA}$ & $0,25 \mathrm{aB}$ & $0,20 \mathrm{abAB}$ & $0,13 \mathrm{aBCD}$ & $0,00 \mathrm{bA}$ \\
& $\mathrm{SP}$ & $0,54 \mathrm{aA}$ & $0,15 \mathrm{bAB}$ & $0,31 \mathrm{bAB}$ & $0,12 \mathrm{bA}$ \\
& $\mathrm{SR}$ & $0,27 \mathrm{aB}$ & $0,07 \mathrm{abB}$ & $0,00 \mathrm{bD}$ & $0,00 \mathrm{bA}$ \\
\hline
\end{tabular}

$\overline{F E ~-~ f e ́ c u l a ~ d e ~ m a n d i o c a ; ~ P V ~-~ p a r a f i n a ~+~ v e r m i c u l i t a ; ~ P A ~-~ p a r a f i n a ~ n o ~ a ́ p i c e ; ~ S P ~-~ s a c o ~ p l a ́ s t i c o ; ~ S R ~-~ s e m ~}$ recobrimento

Médias seguidas de mesma letra (letras minúsculas na horizontal; letras maiúsculas na vertical), não diferem entre si ao nível de $5 \%$ de probabilidade pelo Teste de Tukey. 
Tabela 19. Médias do número de rizomas desenvolvidos e suas respectivas massas de matéria fresca e seca, em gramas, observadas em estacas de primavera de C. rubra, tratadas com 5 tipos de recobrimento e armazenadas por 30,60, 90 ou 120 dias

\begin{tabular}{|c|c|c|c|c|c|}
\hline \multirow{2}{*}{ Parâmetros } & \multirow{2}{*}{$\begin{array}{c}\text { Tipo de } \\
\text { Recobrimento }\end{array}$} & \multicolumn{4}{|c|}{ Período de Armazenamento (dias) } \\
\hline & & 30 & 60 & 90 & 120 \\
\hline \multirow[t]{5}{*}{ Número de Rizomas } & $\mathrm{FE}$ & $0,20 \mathrm{aC}$ & $0,13 \mathrm{aA}$ & $0,03 \mathrm{aBC}$ & $0,00 \mathrm{aA}$ \\
\hline & PV & $0,43 \mathrm{aBC}$ & $0,40 \mathrm{aA}$ & $0,50 \mathrm{aAB}$ & $0,06 \mathrm{aA}$ \\
\hline & PA & $0,70 \mathrm{aAB}$ & $0,30 \mathrm{aBA}$ & $0,10 \mathrm{bB}$ & $0,00 \mathrm{bA}$ \\
\hline & SP & $0,96 \mathrm{aA}$ & $0,36 \mathrm{bcA}$ & $0,70 a b A$ & $0,03 \mathrm{cA}$ \\
\hline & SR & $0,43 \mathrm{aBC}$ & $0,06 \mathrm{aA}$ & $0,00 \mathrm{aC}$ & $0,00 \mathrm{aA}$ \\
\hline \multirow{5}{*}{$\begin{array}{l}\text { Massa de Matéria Fresca } \\
\qquad(\mathrm{g})\end{array}$} & FE & $0,19 \mathrm{aA}$ & $0,15 \mathrm{aA}$ & $0,00 \mathrm{aA}$ & $0,00 \mathrm{aA}$ \\
\hline & PV & $0,37 \mathrm{aA}$ & $0,34 \mathrm{aA}$ & $0,43 \mathrm{aA}$ & $0,06 \mathrm{aA}$ \\
\hline & PA & $0,48 \mathrm{aA}$ & $0,18 \mathrm{aA}$ & $0,18 \mathrm{aA}$ & $0,00 \mathrm{aA}$ \\
\hline & SP & $0,64 \mathrm{aA}$ & $0,10 \mathrm{bcA}$ & $0,56 \mathrm{abA}$ & $0,03 \mathrm{cA}$ \\
\hline & SR & $0,31 \mathrm{aA}$ & $0,04 \mathrm{aA}$ & $0,00 \mathrm{aA}$ & $0,00 \mathrm{aA}$ \\
\hline \multirow{5}{*}{$\begin{array}{l}\text { Massa de Matéria Seca } \\
\qquad(\mathrm{g})\end{array}$} & FE & $0,01 \mathrm{aA}$ & $0,01 \mathrm{aA}$ & $0,00 \mathrm{aB}$ & $0,00 \mathrm{aA}$ \\
\hline & PV & $0,03 \mathrm{aA}$ & $0,03 \mathrm{aA}$ & $0,05 \mathrm{aAB}$ & $0,00 \mathrm{aA}$ \\
\hline & PA & $0,05 \mathrm{aA}$ & $0,01 \mathrm{aA}$ & $0,01 \mathrm{aAB}$ & $0,00 \mathrm{aA}$ \\
\hline & SP & $0,06 \mathrm{aA}$ & $0,01 \mathrm{bA}$ & $0,06 \mathrm{aA}$ & $0,00 \mathrm{bA}$ \\
\hline & SR & $0,03 \mathrm{aA}$ & $0,00 \mathrm{aB}$ & $0,00 \mathrm{aB}$ & $0,00 \mathrm{aA}$ \\
\hline la & & & & & \\
\hline
\end{tabular}

Relacionando o período de armazenamento com os tipos de recobrimento empregados nas estacas, podemos observar que para todos os tipos de recobrimento empregados, o fator tempo de armazenamento é importante no desenvolvimento das estacas, ou seja, quanto menor for o período de armazenamento, mais vigorosa será a brotação e o enraizamento das estacas. Neste caso, o período de 30 dias foi o que apresentou os melhores resultados. Da mesma forma, podemos verificar que alguns tipos de recobrimento foram mais eficazes que outros na manutenção das características das estacas durante o armazenamento. As mais significativas foram o PV e SP, apresentando maiores médias de número e massa de brotos e raízes.

\section{2 Estacas obtidas no outono.}

\section{2. 1 Desenvolvimento de brotos, raízes e formação de rizomas}

A Tabela 20 mostra os valores percentuais de desenvolvimento da parte aérea e raízes e formação de rizomas, respectivamente, subdivididos de acordo com os recobrimentos 
empregados além do tratamento testemunha para C. rubra coletadas no outono. Nesta Tabela, depreende-se que no percentual de parte aérea, o tratamento TT apresentou um ótimo resultado, com 93,33\% de enraizamento. Dessa forma resultados melhores ou iguais a esses podem ser encontrados aos 30 dias de armazenamento em SP/R com 100,00\% e SP/A com $93,33 \%$. Aos 60 dias, PV/R (100,00\%) e SP/R (100,00\%) mostraram resultados eficientes. Para 90 dias, os resultados foram semelhantes (PV/R e SP/R ambos com 100,00\% de enraizamento). Aos 120 dias PV/R (93,33\%) e SP/R (100,00\%) se destacaram. Pode-se dizer também, que para 30 dias de armazenamento, os melhores resultados foram obtidos com SP/R $(100,00 \%)$, SP/A $(93,33 \%)$ e FE/R $(86,66 \%)$, sendo melhores que o tratamento testemunha (86,66\%). Aos 60 dias de armazenamento, destacaram-se SP/P (93,33\%) e PV/R (86,66\%). Para 90 dias de armazenamento, os melhores resultados foram SP/R $(100,00 \%)$ e PV/R (93,33\%). E para 120 dias de armazenamento, os melhores tipos de recobrimento continuam sendo os mesmos SP/R (100,00\%) e PV/R (86,66\%).

Verificando o percentual de desenvolvimento de rizomas (Tabela 20), observa-se que os valores foram baixos, sendo que resultados melhores ou iguais a TT $(33,33 \%)$, foram encontrados apenas em SP/R (33,33\%) e SP/A (33,33\%) para 30 dias de armazenamento; PV/R (60,00\%) e SP/R (53,33\%) para 60 dias; SP/R (46,66\%) para 90 dias e; SP/R (53,33\%) para 120 dias de armazenamento.

O desenvolvimento da parte aérea, raízes e rizomas, entre os diferentes tratamentos variaram muito entre si, como se pode observar na Tabela 20. Tratamentos como SR/R e SR/A nem sequer desenvolveram suas estruturas, simplesmente perdendo sua viabilidade para propagação, demonstrando que tratamentos de recobrimento são de extrema importância no processo de armazenamento das estacas. 
Tabela 20. Percentual do desenvolvimento de brotos, raízes e rizomas em estacas de outono de C. rubra, armazenadas por 30, 60, 90 ou 120 dias, em condições de temperatura ambiente ou refrigerada e submetidas aos diferentes tipos de recobrimento

\begin{tabular}{|c|c|c|c|c|c|c|c|c|c|c|c|c|}
\hline \multirow{3}{*}{ Tipos de Recobrimento } & \multicolumn{12}{|c|}{ Período de Armazenamento (dias) } \\
\hline & \multicolumn{4}{|c|}{ Estacas com Brotos (\%) } & \multicolumn{4}{|c|}{ Estacas com Raízes (\%) } & \multicolumn{4}{|c|}{ Estacas com Rizomas (\%) } \\
\hline & 30 & 60 & 90 & 120 & 30 & 60 & 90 & 120 & 30 & 60 & 90 & 120 \\
\hline FE/R & 86,66 & 33,33 & 0,00 & 0,00 & 86,66 & 33,33 & 0,00 & 6,66 & 26,66 & 20,00 & 0,00 & 0,00 \\
\hline $\mathrm{PV} / \mathrm{R}$ & 86,66 & 100,00 & 100,00 & 93,33 & 73,33 & 86,66 & 93,33 & 86,66 & 20,00 & 60,00 & 20,00 & 20,00 \\
\hline $\mathrm{PA} / \mathrm{R}$ & 80,00 & 66,66 & 13,33 & 0,00 & 73,33 & 73,33 & 13,33 & 0,00 & 20,00 & 6,66 & 0,00 & 0,00 \\
\hline $\mathrm{SP} / \mathrm{R}$ & 100,00 & 100,00 & 100,00 & 100,00 & 100,00 & 93,33 & 100,00 & 100,00 & 33,33 & 53,33 & 46,66 & 53,33 \\
\hline $\mathrm{SR} / \mathrm{R}$ & 0,00 & 0,00 & 0,00 & 0,00 & 0,00 & 0,00 & 0,00 & 0,00 & 0,00 & 0,00 & 0,00 & 0,00 \\
\hline $\mathrm{FE} / \mathrm{A}$ & 20,00 & 6,66 & 0,00 & 0,00 & 20,00 & 6,66 & 0,00 & 0,00 & 0,00 & 0,00 & 0,00 & 0,00 \\
\hline $\mathrm{PV} / \mathrm{A}$ & 86,66 & 80,00 & 46,66 & 53,33 & 80,00 & 80,00 & 53,33 & 40,00 & 20,00 & 13,33 & 26,66 & 26,66 \\
\hline $\mathrm{PA} / \mathrm{A}$ & 33,33 & 0,00 & 0,00 & 0,00 & 20,00 & 0,00 & 0,00 & 0,00 & 0,00 & 0,00 & 0,00 & 0,00 \\
\hline SP/A & 93,33 & 66,66 & 66,66 & 33,33 & 93,33 & 80,00 & 80,00 & 33,33 & 33,33 & 13,33 & 13,33 & 6,66 \\
\hline $\mathrm{SR} / \mathrm{A}$ & 0,00 & 0,00 & 0,00 & 0,00 & 0,00 & 0,00 & 0,00 & 0,00 & 0,00 & 0,00 & 0,00 & 0,00 \\
\hline $\mathrm{TT}^{*}$ & 93,33 & - & - & - & 86,66 & - & - & - & 33,33 & - & - & - \\
\hline
\end{tabular}
temperatura ambiente.

*sem armazenamento 


\section{2. 2 Valores médios de número, massas de matéria fresca e seca de brotos, raízes e rizomas}

A Tabela 21 apresenta as médias do número de brotos, observados aos 30, 60, 90 ou 120 dias de armazenamento, em condições de temperatura ambiente ou refrigerada para estacas de outono de C.rubra para os diferentes tipos de recobrimento, mais a testemunha.

Tabela 21. Médias dos números de brotos desenvolvidos em estacas de outono de $C$. rubra, armazenadas por 30,60, 90 ou 120 dias, em condições de temperatura ambiente ou refrigerada e submetidas aos diferentes tipos de recobrimento

\begin{tabular}{|c|c|c|c|c|}
\hline Tipo de & \multicolumn{4}{|c|}{ Período de Armazenamento (dias) } \\
\hline Recobrimento & 30 & 60 & 90 & 120 \\
\hline $\mathrm{FE} / \mathrm{R}$ & 2,93 ABCDEF & $1,33^{\text {FGHI }}$ & 0,00 & 0,00 \\
\hline $\mathrm{PV} / \mathrm{R}$ & $2,26^{\text {BCDEFG }}$ & $4,66^{\mathrm{A}}$ & $3,86^{A B C}$ & $4,00^{A B}$ \\
\hline $\mathrm{PA} / \mathrm{R}$ & $2,13^{\mathrm{CDEFG}}$ & $2,00^{D E F G}$ & $0,13^{\mathrm{HI}}$ & $0,00^{1}$ \\
\hline $\mathrm{SP} / \mathrm{R}$ & $3,53^{A B C D}$ & $2,86^{\mathrm{BCDEF}}$ & $3,60^{A B C D}$ & $3,40^{A B C D E}$ \\
\hline $\mathrm{SR} / \mathrm{R}$ & $0,00^{\prime}$ & $0,00^{\prime}$ & $0,00^{1}$ & $0,00^{\prime}$ \\
\hline $\mathrm{FE} / \mathrm{A}$ & $0,60^{\mathrm{GHI}}$ & $0,06^{\prime}$ & $0,00^{\prime}$ & $0,00^{\prime}$ \\
\hline $\mathrm{PV} / \mathrm{A}$ & $2,26^{\text {BCCDEFG }}$ & $2,40^{B C C D E F}$ & $1,73^{\mathrm{EFGHI}}$ & $1,60 \mathrm{FGHI}$ \\
\hline $\mathrm{PA} / \mathrm{A}$ & $0,60 \mathrm{GHI}$ & $0,00^{1}$ & $0,00^{\prime}$ & $0,00^{\prime}$ \\
\hline SP/A & $2,53^{\mathrm{BCCDEF}}$ & $1,86^{\mathrm{DEFGH}}$ & $2,40^{B C D E F}$ & $1,20 \mathrm{FGHI}$ \\
\hline $\mathrm{SR} / \mathrm{A}$ & $0,00^{\prime}$ & $0,00^{\prime}$ & $0,00^{\prime}$ & $0,00^{\prime}$ \\
\hline $\mathrm{TT}^{\star}$ & $2,13^{\mathrm{CDEFG}}$ & - & - & - \\
\hline
\end{tabular}

Observando a Tabela 21, de média do número de brotos, verifica-se que aos 30 e 90 dias de armazenamento, nenhum dos tratamentos conseguiu superar estatisticamente o tratamento testemunha, que apresentou uma média de 2,13 brotos.

Os únicos tratamentos que superaram TT estatisticamente, foram PV/R em 60 e 120 dias de armazenamento, com 4,66 e 4,00 brotos de média, respectivamente.

A Tabela 22 apresenta as médias de matéria fresca (em gramas) de brotos, observados aos 30, 60, 90 ou 120 dias de armazenamento, em condições de temperatura ambiente ou refrigerada para estacas de outono de C. rubra para os diferentes tipos de recobrimento, mais a testemunha. Por esta Tabela (Tabela 22), de médias da massa de matéria fresca (em gramas), verifica-se que a testemunha (TT), mostrou resultado de 3,90 gramas.

Os únicos tratamentos que diferiram estatisticamente do tratamento testemunha foram PV/R com 9,72 g e SP/R, com 11,67 g para 60 dias de armazenamento e em 120 dias, apenas $\mathrm{SP} / \mathrm{R}$ com 9,16 g. Os demais resultados foram estatisticamente semelhantes em relação ao tratamento testemunha. 
Tabela 22. Médias das massas de matéria fresca de brotos, em gramas, desenvolvidos em estacas de outono de C. rubra, armazenadas por 30, 60, 90 ou 120 dias, em condições de temperatura ambiente ou refrigerada e submetidas aos diferentes tipos de recobrimento

\begin{tabular}{|c|c|c|c|c|}
\hline \multirow{2}{*}{$\begin{array}{c}\text { Tipo de } \\
\text { Recobrimento }\end{array}$} & \multicolumn{4}{|c|}{ Período de Armazenamento (dias) } \\
\hline & 30 & 60 & 90 & 120 \\
\hline $\mathrm{FE} / \mathrm{R}$ & $5,16^{\mathrm{BCDEFG}}$ & $3,62^{\mathrm{DEFG}}$ & $0,00^{\mathrm{G}}$ & $0,00^{\mathrm{G}}$ \\
\hline $\mathrm{PV} / \mathrm{R}$ & $5,01^{\mathrm{BCDEFG}}$ & $9,72 \mathrm{AB}$ & $6,63^{\mathrm{ABCDE}}$ & $8,24^{A B C D}$ \\
\hline $\mathrm{PA} / \mathrm{R}$ & $3,46^{\mathrm{DEFG}}$ & 4,29 CDEFG & $0,29^{F G}$ & $0,00^{\mathrm{G}}$ \\
\hline $\mathrm{SP} / \mathrm{R}$ & $6,60^{\mathrm{ABCDE}}$ & $11,67^{\mathrm{A}}$ & $8,33^{A B C D}$ & $9,16^{\mathrm{ABC}}$ \\
\hline $\mathrm{SR} / \mathrm{R}$ & $0,00^{\mathrm{G}}$ & $0,00^{G}$ & $0,00^{\mathrm{G}}$ & $0,00^{\mathrm{G}}$ \\
\hline $\mathrm{FE} / \mathrm{A}$ & $0,55^{F G}$ & $0,02^{\mathrm{G}}$ & $0,00^{\mathrm{G}}$ & $0,00^{\mathrm{G}}$ \\
\hline $\mathrm{PV} / \mathrm{A}$ & $5,28^{\mathrm{BCDEF}}$ & $6,52 \mathrm{ABCDE}$ & $3,17^{\mathrm{DEFG}}$ & $3,18^{\mathrm{DEFG}}$ \\
\hline $\mathrm{PA} / \mathrm{A}$ & $0,25 \mathrm{FG}$ & $0,00^{\mathrm{G}}$ & $0,00^{\mathrm{G}}$ & $0,00^{\mathrm{G}}$ \\
\hline $\mathrm{SP} / \mathrm{A}$ & $6,88^{A B C D E}$ & $3,96^{\mathrm{CDEFG}}$ & $4,65^{\mathrm{BCDEFG}}$ & $2,06^{\mathrm{EFG}}$ \\
\hline $\mathrm{SR} / \mathrm{A}$ & $0,00^{\mathrm{G}}$ & $0,00^{G}$ & $0,00^{\mathrm{G}}$ & $0,00^{\mathrm{G}}$ \\
\hline $\mathrm{TT}^{*}$ & $3,90^{\mathrm{DEFG}}$ & - & - & - \\
\hline
\end{tabular}

A Tabela 23 apresenta as médias de matéria seca (em gramas) de brotos, observados aos 30, 60, 90 ou 120 dias de armazenamento, em condições de temperatura ambiente ou refrigerada para estacas de outono de $C$. rubra para os diferentes tipos de recobrimento, mais a testemunha.

Tabela 23. Médias das massas de matéria seca de brotos, em gramas, desenvolvidos em estacas de outono de C. rubra, armazenadas por 30,60, 90 ou 120 dias, em condições de temperatura ambiente ou refrigerada e submetidas aos diferentes tipos de recobrimento

\begin{tabular}{|c|c|c|c|c|}
\hline Tipo de & \multicolumn{4}{|c|}{ Período de Armazenamento (dias) } \\
\hline Recobrimento & 30 & 60 & 90 & 120 \\
\hline $\mathrm{FE} / \mathrm{R}$ & $0,74^{\text {CDEFG }}$ & $0,76^{\text {CDEFG }}$ & $0,00^{\mathrm{G}}$ & $0,00^{\mathrm{G}}$ \\
\hline $\mathrm{PV} / \mathrm{R}$ & $0,83^{\mathrm{CDEFG}}$ & $1,91^{A B}$ & $1,16^{\mathrm{BCDEF}}$ & $1,51^{\mathrm{ABCD}}$ \\
\hline $\mathrm{PA} / \mathrm{R}$ & $0,52^{\mathrm{DEFG}}$ & $0,77^{\mathrm{CDEFG}}$ & $0,05^{\mathrm{G}}$ & $0,00^{\mathrm{G}}$ \\
\hline $\mathrm{SP} / \mathrm{R}$ & $0,98^{\mathrm{BCDEFG}}$ & $2,21^{\mathrm{A}}$ & $1,46^{\mathrm{ABCDE}}$ & $1,68^{A B C}$ \\
\hline $\mathrm{SR} / \mathrm{R}$ & $0,00^{\mathrm{G}}$ & $0,00^{G}$ & $0,00^{\mathrm{G}}$ & $0,00^{\mathrm{G}}$ \\
\hline $\mathrm{FE} / \mathrm{A}$ & $0,06^{G}$ & $0,00^{\mathrm{G}}$ & $0,00^{\mathrm{G}}$ & $0,00^{\mathrm{G}}$ \\
\hline $\mathrm{PV} / \mathrm{A}$ & $0,88^{\mathrm{CDEFG}}$ & 1,23 ABCDEF & $0,58^{\mathrm{DEFG}}$ & $0,56^{\mathrm{DEFG}}$ \\
\hline $\mathrm{PA} / \mathrm{A}$ & $0,03^{\mathrm{G}}$ & $0,00^{G}$ & $0,00^{\mathrm{G}}$ & $0,00^{\mathrm{G}}$ \\
\hline SP/A & $1,12^{\mathrm{BCDEF}}$ & $0,69 \mathrm{CDEFG}$ & $0,79^{\mathrm{CDEFG}}$ & $0,34 \mathrm{FG}$ \\
\hline $\mathrm{SR} / \mathrm{A}$ & $0,00^{\mathrm{G}}$ & $0,00^{\mathrm{G}}$ & $0,00^{\mathrm{G}}$ & $0,00^{\mathrm{G}}$ \\
\hline $\mathrm{TT}^{*}$ & $0,48^{\mathrm{EFG}}$ & - & - & - \\
\hline
\end{tabular}

De acordo com a Tabela 23, os tratamentos SP/R $(2,21 \mathrm{~g})$ e PV/R $(1,91 \mathrm{~g})$ para 60 dias de armazenamento confirmam os resultados encontrados na Tabela 45, sendo estatisticamente 
melhores que o tratamento testemunha, assim como para os mesmos tratamentos de recobrimento armazenados por 120 dias (PV/R com 1,51 g e SP/R com 1,68 g). Os demais resultados não diferiram de TT, que apresentou uma média de $0,48 \mathrm{~g}$.

A Tabela 24 apresenta as médias dos números de raízes, observados aos 30, 60, 90 ou 120 dias de armazenamento em condições de temperatura ambiente ou refrigerada para estacas de outono de $C$. rubra para os diferentes tipos de recobrimento, mais a testemunha.

Tabela 24. Médias dos números de raízes desenvolvidas em estacas de outono de $C$. rubra, armazenadas por 30, 60, 90 ou 120 dias, em condições de temperatura ambiente ou refrigerada e submetidas aos diferentes tipos de recobrimento

\begin{tabular}{|c|c|c|c|c|}
\hline Tipo de & \multicolumn{4}{|c|}{ Período de Armazenamento (dias) } \\
\hline Recobrimento & 30 & 60 & 90 & 120 \\
\hline FE/R & $5,60^{\mathrm{BCDEF}}$ & $3,33^{\text {CDEFG }}$ & $0,00^{G}$ & $0,00^{G}$ \\
\hline $\mathrm{PV} / \mathrm{R}$ & $1,86^{\text {DEFG }}$ & $5,46^{\text {BCDEF }}$ & $3,86^{\mathrm{CDEFG}}$ & $5,53^{\mathrm{BCDEF}}$ \\
\hline $\mathrm{PA} / \mathrm{R}$ & $2.66^{\mathrm{DEFG}}$ & $4,06^{\text {CDEFG }}$ & $0,13^{G}$ & $0,00^{G}$ \\
\hline SP/R & $5,80^{\mathrm{BCDE}}$ & $9,20^{A B}$ & $7,73^{\mathrm{BC}}$ & $13,60^{\mathrm{A}}$ \\
\hline $\mathrm{SR} / \mathrm{R}$ & $0,00^{G}$ & $0,00^{G}$ & $0,00^{G}$ & $0,00^{G}$ \\
\hline $\mathrm{FE} / \mathrm{A}$ & $1.00^{\mathrm{EFG}}$ & $0.06^{G}$ & $0.00^{G}$ & $0.00^{G}$ \\
\hline $\mathrm{PV} / \mathrm{A}$ & 3,93 CDEFG & $4,33^{\mathrm{BCDEFG}}$ & $4,46^{\text {BCDEFG }}$ & $4,33^{\mathrm{BCDEFG}}$ \\
\hline $\mathrm{PA} / \mathrm{A}$ & $0,73^{\mathrm{FG}}$ & $0,00^{G}$ & $0,00^{G}$ & $0,00^{G}$ \\
\hline SP/A & $6,00^{\mathrm{BCD}}$ & $6,20^{\mathrm{BCD}}$ & $6,06^{\mathrm{BCD}}$ & $3,33^{\mathrm{CDEFG}}$ \\
\hline $\mathrm{SR} / \mathrm{A}$ & $0,00^{G}$ & $0,00^{G}$ & $0,00^{G}$ & $0,00^{G}$ \\
\hline $\mathrm{TT}^{\star}$ & $4,40^{\mathrm{BCDEFG}}$ & - & , & - \\
\hline
\end{tabular}

Na Tabela 24, de média do número de raízes, nota-se que apesar dos bons resultados apenas o tratamento SP/R, em 120 dias de armazenamento, com 13,60 raízes, foi estatisticamente melhor do que o tratamento TT (testemunha), com 4,40 raízes. Sendo que os demais tratamentos foram iguais ou piores, estatisticamente, que TT.

A Tabela 25 apresenta médias das massas de matéria fresca de raízes (em gramas), observados aos 30,60, 90 ou 120 dias de armazenamento, em condições de temperatura ambiente ou refrigerada para estacas de outono de $C$. rubra para os diferentes tipos de recobrimento, mais a testemunha.

Nesta Tabela, de média de massa de matéria fresca de raízes, observando o tratamento TT, percebe-se que nenhum dos tratamentos foi melhor estatisticamente, ou seja, nenhum dos tratamentos diferiu da testemunha. 
Tabela 25. Médias das massas de matéria fresca de raízes, em gramas, desenvolvidas em estacas de outono de C. rubra, armazenadas por 30, 60, 90 ou 120 dias, em condições de temperatura ambiente ou refrigerada e submetidas aos diferentes tipos de recobrimento

\begin{tabular}{|c|c|c|c|c|}
\hline Tipo de & \multicolumn{4}{|c|}{ Período de Armazenamento (dias) } \\
\hline Recobrimento & 30 & 60 & 90 & 120 \\
\hline $\mathrm{FE} / \mathrm{R}$ & $1,30^{A B C}$ & $0,51^{\mathrm{BCDE}}$ & $0,00^{\mathrm{E}}$ & $0,20^{\mathrm{DE}}$ \\
\hline $\mathrm{PV} / \mathrm{R}$ & $0,35^{\mathrm{CDE}}$ & $1,12^{\mathrm{ABCD}}$ & $0,84^{A B C D E}$ & $1,32^{A B C}$ \\
\hline $\mathrm{PA} / \mathrm{R}$ & $0,47^{\mathrm{BCDE}}$ & $0,44^{\mathrm{BCDE}}$ & $0,02^{E}$ & $0,00^{\mathrm{E}}$ \\
\hline $\mathrm{SP} / \mathrm{R}$ & $1,30^{\mathrm{ABC}}$ & $1,48^{A B}$ & $1,64^{\mathrm{A}}$ & $0,32^{\mathrm{CDE}}$ \\
\hline $\mathrm{SR} / \mathrm{R}$ & $0,00^{\mathrm{E}}$ & $0,00^{\mathrm{E}}$ & $0,00^{\mathrm{E}}$ & $0,00^{\mathrm{E}}$ \\
\hline $\mathrm{FE} / \mathrm{A}$ & $0,13^{\mathrm{DE}}$ & $0,00^{\mathrm{E}}$ & $0,00^{\mathrm{E}}$ & $0,00^{\mathrm{E}}$ \\
\hline $\mathrm{PV} / \mathrm{A}$ & $0,78^{A B C D E}$ & $0,81^{A B C D E}$ & $0,82^{A B C D E}$ & $0,70^{\mathrm{ABCDE}}$ \\
\hline $\mathrm{PA} / \mathrm{A}$ & $0,04^{\mathrm{E}}$ & $0,00^{\mathrm{E}}$ & $0,00^{\mathrm{E}}$ & $0,00^{\mathrm{E}}$ \\
\hline SP/A & $1,31^{A B C}$ & $0,66^{\mathrm{ABCDE}}$ & 0,82 ABCDE & $0,40^{\mathrm{CDE}}$ \\
\hline SR/A & $0,00^{\mathrm{E}}$ & $0,00^{\mathrm{E}}$ & $0,00^{\mathrm{E}}$ & $0,00^{\mathrm{E}}$ \\
\hline $\mathrm{TT}^{*}$ & $1,03^{A B C D E}$ & - & - & - \\
\hline
\end{tabular}

A Tabela 26 apresenta médias das massas de matéria seca de raízes (em gramas), observados aos 30,60, 90 ou 120 dias de armazenamento em condições de temperatura ambiente ou refrigerada para estacas de outono de C. rubra para os diferentes tipos de recobrimento, mais a testemunha.

Tabela 26. Médias das massas de matéria seca de raízes, em gramas, desenvolvidas em estacas de outono de C. rubra, armazenadas por 30, 60, 90 ou 120 dias, em condições de temperatura ambiente ou refrigerada e submetidas aos diferentes tipos de recobrimento

\begin{tabular}{|c|c|c|c|c|}
\hline Tipo de & \multicolumn{4}{|c|}{ Período de Armazenamento (dias) } \\
\hline Recobrimento & 30 & 60 & 90 & 120 \\
\hline $\mathrm{FE} / \mathrm{R}$ & $0,16^{\mathrm{ABCDE}}$ & $0,12^{\mathrm{BCDE}}$ & $0,00^{E}$ & $0,00^{\mathrm{DE}}$ \\
\hline $\mathrm{PV} / \mathrm{R}$ & $0,05^{\mathrm{CDE}}$ & $0,19 \mathrm{ABCD}$ & $0,10^{\mathrm{BCDE}}$ & $0,13^{\mathrm{ABCDE}}$ \\
\hline $\mathrm{PA} / \mathrm{R}$ & $0,05 \mathrm{CDE}$ & $0,06^{\mathrm{BCDE}}$ & $0,01^{\mathrm{DE}}$ & $0,00^{\mathrm{E}}$ \\
\hline $\mathrm{SP} / \mathrm{R}$ & $0,18^{\mathrm{ABCDE}}$ & $0,25^{A B}$ & $0,21^{A B C}$ & $0,32^{A}$ \\
\hline $\mathrm{SR} / \mathrm{R}$ & $0,00^{\mathrm{E}}$ & $0,00^{\mathrm{E}}$ & $0,00^{\mathrm{E}}$ & $0,00^{\mathrm{E}}$ \\
\hline $\mathrm{FE} / \mathrm{A}$ & $0,01^{\mathrm{DE}}$ & $0,00^{\mathrm{E}}$ & $0,00^{\mathrm{E}}$ & $0,00^{\mathrm{E}}$ \\
\hline $\mathrm{PV} / \mathrm{A}$ & $0,10^{\mathrm{BCDE}}$ & $0,11^{\mathrm{BCDE}}$ & $0,15^{\mathrm{ABCDE}}$ & $0,09^{B C D E}$ \\
\hline $\mathrm{PA} / \mathrm{A}$ & $0,00^{\mathrm{DE}}$ & $0,00^{\mathrm{E}}$ & $0,00^{\mathrm{E}}$ & $0,00^{\mathrm{E}}$ \\
\hline SP/A & 0,19 ABCDE & $0,05^{\mathrm{CDE}}$ & $0,10^{\mathrm{BCDE}}$ & $0,04^{\mathrm{CDE}}$ \\
\hline $\mathrm{SR} / \mathrm{A}$ & $0,00^{\mathrm{E}}$ & $0,00^{\mathrm{E}}$ & $0,00^{\mathrm{E}}$ & $0,00^{\mathrm{E}}$ \\
\hline $\mathrm{TT}^{*}$ & $0,13^{\mathrm{ABCDE}}$ & - & - & - \\
\hline
\end{tabular}

A Tabela 26, de média de massa de matéria seca, mostra que nenhum dos tratamentos conseguiu superar estatisticamente o tratamento testemunha. 
A Tabela 27 mostra as médias do número de rizomas observados aos 30,60, 90 ou 120 dias de armazenamento em condições de temperatura ambiente ou refrigerada para estacas de outono de C. rubra para os diferentes tipos de recobrimento, mais a testemunha.

Tabela 27. Médias dos números de rizomas desenvolvidos em estacas de outono de $C$. rubra, armazenadas por 30, 60, 90 ou 120 dias, em condições de temperatura ambiente ou refrigerada e submetidas aos diferentes tipos de recobrimento

\begin{tabular}{|c|c|c|c|c|}
\hline Tipo de & \multicolumn{4}{|c|}{ Período de Armazenamento (dias) } \\
\hline Recobrimento & 30 & 60 & 90 & 120 \\
\hline $\mathrm{FE} / \mathrm{R}$ & $0,40^{A B C}$ & $0,26^{A B C}$ & $0,00^{\mathrm{C}}$ & $0,00^{C}$ \\
\hline $\mathrm{PV} / \mathrm{R}$ & $0,26^{A B C}$ & $0,60^{\mathrm{ABC}}$ & $0,26^{A B C}$ & $0,26^{A B C}$ \\
\hline $\mathrm{PA} / \mathrm{R}$ & $0,20^{A B C}$ & $0,06^{\mathrm{BC}}$ & $0,00^{\mathrm{C}}$ & $0,00^{\mathrm{C}}$ \\
\hline $\mathrm{SP} / \mathrm{R}$ & $0,60^{A B C}$ & $0,66^{A B}$ & $0,46^{A B C}$ & $0,80^{\mathrm{A}}$ \\
\hline $\mathrm{SR} / \mathrm{R}$ & $0,00^{\mathrm{C}}$ & $0,00^{\mathrm{C}}$ & $0,00^{\mathrm{C}}$ & $0,00^{\mathrm{C}}$ \\
\hline $\mathrm{FE} / \mathrm{A}$ & $0,00^{\mathrm{C}}$ & $0,00^{\mathrm{C}}$ & $0,00^{\mathrm{C}}$ & $0,00^{\mathrm{C}}$ \\
\hline $\mathrm{PV} / \mathrm{A}$ & $0,26^{A B C}$ & $0,13^{\mathrm{BC}}$ & $0,46^{A B C}$ & $0,26^{A B C}$ \\
\hline $\mathrm{PA} / \mathrm{A}$ & $0,00^{\mathrm{C}}$ & $0,00^{\mathrm{C}}$ & $0,00^{\mathrm{C}}$ & $0,00^{c}$ \\
\hline SP/A & $0,40^{A B C}$ & $0,26^{A B C}$ & $0,26^{A B C}$ & $0,13^{\mathrm{BC}}$ \\
\hline $\mathrm{SR} / \mathrm{A}$ & $0,00^{c}$ & $0,00^{\mathrm{C}}$ & $0,00^{\mathrm{C}}$ & $0,00^{\mathrm{C}}$ \\
\hline $\mathrm{TT}^{*}$ & $0,33^{A B C}$ & - & - & - \\
\hline
\end{tabular}

De acordo com a Tabela 27, de média do número de rizomas, o tratamento testemunha TT apresentou uma média de 0,33 rizomas. Pode-se observar também, que desse modo, nenhum dos tratamentos diferiu estatisticamente, tanto com resultados superiores, como inferiores ao tratamento testemunha. Na prática esses valores são muito baixos.

A Tabela 28 mostra as médias das massas de matéria fresca de rizomas (em gramas) observados aos $30,60,90$ ou 120 dias de armazenamento em condições de temperatura ambiente ou refrigerada para estacas de outono de $C$. rubra para os diferentes tipos de recobrimento, mais a testemunha.

Segundo a Tabela 28, de média de massa de matéria fresca de rizomas, aos 30 dias de armazenamento, novamente nenhum dos tratamentos foi estatisticamente melhor do que o tratamento testemunha. 
Tabela 28. Médias das massas de matéria fresca de rizomas, em gramas, desenvolvidos em estacas de outono de C. rubra, armazenadas por 30, 60, 90 ou 120 dias, em condições de temperatura ambiente ou refrigerada e submetidas aos diferentes tipos de recobrimento

\begin{tabular}{cllll}
\hline Tipo de & \multicolumn{4}{c}{ Período de Armazenamento (dias) } \\
Recobrimento & 30 & 60 & 90 & 120 \\
\hline $\mathrm{FE} / \mathrm{R}$ & $0,16^{\mathrm{AB}}$ & $0,17^{\mathrm{AB}}$ & $0,00^{\mathrm{B}}$ & $0,00^{\mathrm{B}}$ \\
$\mathrm{PV} / \mathrm{R}$ & $0,05^{\mathrm{B}}$ & $0,43^{\mathrm{AB}}$ & $0,31^{\mathrm{AB}}$ & $0,16^{\mathrm{AB}}$ \\
$\mathrm{PA} / \mathrm{R}$ & $0,05^{\mathrm{B}}$ & $0,00^{\mathrm{B}}$ & $0,00^{\mathrm{B}}$ & $0,00^{\mathrm{B}}$ \\
$\mathrm{SP} / \mathrm{R}$ & $0,15^{\mathrm{AB}}$ & $0,71^{\mathrm{A}}$ & $0,70^{\mathrm{A}}$ & $0,57^{\mathrm{AB}}$ \\
$\mathrm{SR} / \mathrm{R}$ & $0,00^{\mathrm{B}}$ & $0,00^{\mathrm{B}}$ & $0,00^{\mathrm{B}}$ & $0,00^{\mathrm{B}}$ \\
$\mathrm{FE} / \mathrm{A}$ & $0,00^{\mathrm{B}}$ & $0,00^{\mathrm{B}}$ & $0,00^{\mathrm{B}}$ & $0,00^{\mathrm{B}}$ \\
$\mathrm{PV} / \mathrm{A}$ & $0,09^{\mathrm{AB}}$ & $0,01^{\mathrm{B}}$ & $0,53^{\mathrm{AB}}$ & $0,13^{\mathrm{AB}}$ \\
$\mathrm{PA} / \mathrm{A}$ & $0,00^{\mathrm{B}}$ & $0,00^{\mathrm{B}}$ & $0,00^{\mathrm{B}}$ & $0,00^{\mathrm{B}}$ \\
$\mathrm{SP} / \mathrm{A}$ & $0,33^{\mathrm{AB}}$ & $0,10^{\mathrm{AB}}$ & $0,22^{\mathrm{AB}}$ & $0,12^{\mathrm{AB}}$ \\
$\mathrm{SR} / \mathrm{A}$ & $0,00^{\mathrm{B}}$ & $0,00^{\mathrm{B}}$ & $0,00^{\mathrm{B}}$ & $0,00^{\mathrm{B}}$ \\
TT & $0,11^{\mathrm{AB}}$ & - & - & - \\
\hline FE - fécula de mandioca; PV - parafina + vermiculita; PA - parafina no ápice; SP - saco plástico; SR - sem \\
recobrimento; TT - testemunha; R - refrigerado; A - temperatura ambiente. \\
* sem armaznamento. \\
Médias seguidas de mesma letra na coluna, não diferem entre si ao nível de $5 \%$ de probabilidade pelo Teste de Tukey.
\end{tabular}

A Tabela 29 mostra as médias das massas de matéria seca de rizomas (em gramas) observados aos 30,60, 90 ou 120 dias de armazenamento em condições de temperatura ambiente ou refrigerada para estacas de outono de $C$. rubra para os diferentes tipos de recobrimento, mais a testemunha.

Tabela 29. Médias das massas de matéria seca de rizomas, em gramas, desenvolvidos em estacas de outono de C. rubra, armazenadas por 30, 60, 90 ou 120 dias, em condições de temperatura ambiente ou refrigerada e submetidas aos diferentes tipos de recobrimento

\begin{tabular}{cllll}
\hline Tipo de & \multicolumn{4}{c}{ Período de Armazenamento (dias) } \\
Recobrimento & 30 & 60 & 90 & 120 \\
\hline FE/R & $0,01^{\mathrm{AB}}$ & $0,02^{\mathrm{AB}}$ & $0,00^{\mathrm{B}}$ & $0,00^{\mathrm{B}}$ \\
$\mathrm{PV} / \mathrm{R}$ & $0,00^{\mathrm{B}}$ & $0,03^{\mathrm{AB}}$ & $0,03^{\mathrm{AB}}$ & $0,01^{\mathrm{AB}}$ \\
$\mathrm{PA} / \mathrm{R}$ & $0,00^{\mathrm{B}}$ & $0,00^{\mathrm{B}}$ & $0,00^{\mathrm{B}}$ & $0,00^{\mathrm{B}}$ \\
$\mathrm{SP} / \mathrm{R}$ & $0,01^{\mathrm{AB}}$ & $0,07^{\mathrm{A}}$ & $0,06^{\mathrm{AB}}$ & $0,06^{\mathrm{AB}}$ \\
$\mathrm{SR} / \mathrm{R}$ & $0,00^{\mathrm{B}}$ & $0,00^{\mathrm{B}}$ & $0,00^{\mathrm{B}}$ & $0,00^{\mathrm{B}}$ \\
$\mathrm{FE} / \mathrm{A}$ & $0,00^{\mathrm{B}}$ & $0,00^{\mathrm{B}}$ & $0,00^{\mathrm{B}}$ & $0,00^{\mathrm{B}}$ \\
$\mathrm{PV} / \mathrm{A}$ & $0,00^{\mathrm{AB}}$ & $0,00^{\mathrm{B}}$ & $0,06^{\mathrm{AB}}$ & $0,01^{\mathrm{AB}}$ \\
$\mathrm{PA} / \mathrm{A}$ & $0,00^{\mathrm{B}}$ & $0,00^{\mathrm{B}}$ & $0,00^{\mathrm{B}}$ & $0,00^{\mathrm{B}}$ \\
$\mathrm{SP} / \mathrm{A}$ & $0,03^{\mathrm{AB}}$ & $0,00^{\mathrm{AB}}$ & $0,01^{\mathrm{AB}}$ & $0,01^{\mathrm{AB}}$ \\
SR/A & $0,00^{\mathrm{B}}$ & $0,00^{\mathrm{B}}$ & $0,00^{\mathrm{B}}$ & $0,00^{\mathrm{B}}$ \\
TT & $0,00^{\mathrm{AB}}$ & - & - & - \\
\hline FE - fécula de mandioca; $\mathrm{PV}$ - parafina + vermiculita; PA - parafina no ápice; SP - saco plástico; SR - sem \\
recobrimento; TT - testemunha; R - refrigerado; A - temperatura ambiente. \\
* sem armazenamento. \\
Médias seguidas de mesma letra na coluna, não diferem entre si ao nível de 5\% de probabilidade pelo Teste de Tukey.
\end{tabular}


Confirmando os dados da Tabela 28, a Tabela 29, de média de massa de matéria seca de rizomas, mostra que nenhum dos tratamentos diferiu estatisticamente do tratamento testemunha.

\section{2. 3 Relação entre condições e períodos de armazenamento}

As Tabelas 30, 31 e 32 apresentam as análises das médias de número de brotos, raízes e rizomas, respectivamente, desenvolvidos nas estacas de $C$. rubra, além da massa de matéria fresca e seca dos mesmos, relacionados com os períodos (30, 60, 90 ou 120 dias) e as condições de armazenamento (temperatura ambiente e sob refrigeração).

Tabela 30. Médias do número de brotos desenvolvidos e suas respectivas massas de matéria fresca e seca, em gramas, observadas em estacas de outono de C. rubra, armazenadas por 30, 60, 90 ou 120 dias, em condições de temperatura ambiente ou sob refrigeração

\begin{tabular}{|c|c|c|c|}
\hline \multirow[b]{2}{*}{ Parâmetros } & \multirow{2}{*}{$\begin{array}{c}\text { Período de } \\
\text { Armazenamento } \\
\text { (dias) }\end{array}$} & \multicolumn{2}{|c|}{ Condição de Armazenamento } \\
\hline & & $\begin{array}{l}\text { Ambiente } \\
\text { Refrigerado }\end{array}$ & $\begin{array}{c}\text { Temperatura } \\
\text { Ambiente }\end{array}$ \\
\hline Número de Brotos & $\begin{array}{c}30 \\
60 \\
90 \\
120\end{array}$ & $\begin{array}{l}2,17 \mathrm{aA} \\
2,17 \mathrm{aA} \\
1,52 \mathrm{bA} \\
1,48 \mathrm{bA}\end{array}$ & $\begin{array}{l}1,20 \mathrm{aB} \\
0,86 \mathrm{aB} \\
0,82 \mathrm{aB} \\
0,56 \mathrm{aB}\end{array}$ \\
\hline $\begin{array}{l}\text { Massa de Matéria } \\
\text { Fresca } \\
\text { (g) }\end{array}$ & $\begin{array}{c}30 \\
60 \\
90 \\
120\end{array}$ & $\begin{array}{l}4,04 \mathrm{bA} \\
5,85 \mathrm{aA} \\
3,05 \mathrm{bA} \\
3,48 \mathrm{bA}\end{array}$ & $\begin{array}{l}2,59 \mathrm{aA} \\
2,10 \mathrm{aB} \\
1,56 \mathrm{aA} \\
1,04 \mathrm{aB}\end{array}$ \\
\hline $\begin{array}{c}\text { Massa de Matéria } \\
\text { Seca } \\
(\mathrm{g})\end{array}$ & $\begin{array}{c}30 \\
60 \\
90 \\
120\end{array}$ & $\begin{array}{l}0,61 \mathrm{bA} \\
1,13 \mathrm{aA} \\
0,53 \mathrm{bA} \\
0,63 \mathrm{bA}\end{array}$ & $\begin{array}{l}0,42 \mathrm{aA} \\
0,38 \mathrm{aB} \\
0,27 \mathrm{aA} \\
0,18 \mathrm{bA}\end{array}$ \\
\hline
\end{tabular}

Médias seguidas de mesma letra (letras minúsculas na vertical; letras maiúsculas na horizontal, para cada item), não diferem entre si ao nível de $5 \%$ de probabilidade pelo Teste de Tukey. 
Tabela 31. Médias do número de raízes desenvolvidas e suas respectivas massas de matéria fresca e seca, em gramas, observadas em estacas de outono de C. rubra, armazenadas por 30, 60, 90 ou 120 dias, em condições de temperatura ambiente ou sob refrigeração

\begin{tabular}{|c|c|c|c|}
\hline \multirow[b]{2}{*}{ Parâmetros } & \multirow{2}{*}{$\begin{array}{c}\text { Período de } \\
\text { Armazenamento } \\
\text { (dias) }\end{array}$} & \multicolumn{2}{|c|}{ Condição de Armazenamento } \\
\hline & & $\begin{array}{l}\text { Ambiente } \\
\text { Refrigerado }\end{array}$ & $\begin{array}{c}\text { Temperatura } \\
\text { Ambiente }\end{array}$ \\
\hline Número de Raízes & $\begin{array}{c}30 \\
60 \\
90 \\
120\end{array}$ & $\begin{array}{c}3,18 \mathrm{abA} \\
4,41 \mathrm{aA} \\
2,34 \mathrm{bA} \\
3,82 \mathrm{abA}\end{array}$ & $\begin{array}{l}2,33 \mathrm{aA} \\
2,12 \mathrm{aB} \\
2,10 \mathrm{aA} \\
1,53 \mathrm{aB}\end{array}$ \\
\hline $\begin{array}{l}\text { Massa de Matéria } \\
\text { Fresca } \\
\text { (g) }\end{array}$ & $\begin{array}{c}30 \\
60 \\
90 \\
120\end{array}$ & $\begin{array}{l}0,68 \text { aA } \\
0,71 \text { aA } \\
0,50 \text { aA } \\
0,36 \text { aA }\end{array}$ & $\begin{array}{l}0,45 \mathrm{aA} \\
0,29 \mathrm{aB} \\
0,32 \mathrm{aA} \\
0,22 \mathrm{aA}\end{array}$ \\
\hline $\begin{array}{c}\text { Massa de Matéria } \\
\text { Seca } \\
(\mathrm{g})\end{array}$ & $\begin{array}{c}30 \\
60 \\
90 \\
120\end{array}$ & $\begin{array}{l}0,09 \text { aA } \\
0,12 \text { aA } \\
0,06 \text { aA } \\
0,09 \text { aA }\end{array}$ & $\begin{array}{l}0,06 \mathrm{aA} \\
0,03 \mathrm{aB} \\
0,05 \mathrm{aA} \\
0,02 \mathrm{aB}\end{array}$ \\
\hline
\end{tabular}

Médias seguidas de mesma letra (letras minúsculas na vertical; letras maiúsculas na horizontal, para cada item), não diferem entre si ao nível de $5 \%$ de probabilidade pelo Teste de Tukey.

Tabela 32. Médias do número de rizomas desenvolvidos e suas respectivas massas de matéria fresca e seca, em gramas, observadas em estacas de outono de C. rubra, armazenadas por 30, 60, 90 ou 120 dias, em condições de temperatura ambiente ou sob refrigeração

\begin{tabular}{|c|c|c|c|}
\hline \multirow[b]{2}{*}{ Parâmetros } & \multirow{2}{*}{$\begin{array}{c}\text { Período de } \\
\text { Armazenamento } \\
\text { (dias) }\end{array}$} & \multicolumn{2}{|c|}{ Condição de Armazenamento } \\
\hline & & $\begin{array}{l}\text { Ambiente } \\
\text { Refrigerado }\end{array}$ & $\begin{array}{c}\text { Temperatura } \\
\text { Ambiente }\end{array}$ \\
\hline Número de Rizomas & $\begin{array}{c}30 \\
60 \\
90 \\
120\end{array}$ & $\begin{array}{l}0,29 \mathrm{aA} \\
0,32 \mathrm{aA} \\
0,14 \mathrm{aA} \\
0,21 \mathrm{aA}\end{array}$ & $\begin{array}{l}0,13 \mathrm{aA} \\
0,08 \mathrm{aB} \\
0,14 \mathrm{aA} \\
0,08 \mathrm{aA}\end{array}$ \\
\hline $\begin{array}{l}\text { Massa de Matéria } \\
\text { Fresca } \\
\text { (g) }\end{array}$ & $\begin{array}{c}30 \\
60 \\
90 \\
120\end{array}$ & $\begin{array}{l}0,08 \text { aA } \\
0,26 a A \\
0,20 a A \\
0,14 a A\end{array}$ & $\begin{array}{l}0,08 \mathrm{aA} \\
0,02 \mathrm{aB} \\
0,15 \mathrm{aA} \\
0,05 \mathrm{aA}\end{array}$ \\
\hline $\begin{array}{c}\text { Massa de Matéria } \\
\text { Seca } \\
(\mathrm{g})\end{array}$ & $\begin{array}{c}30 \\
60 \\
90 \\
120\end{array}$ & $\begin{array}{l}0,00 \mathrm{aA} \\
0,02 \mathrm{aA} \\
0,02 \mathrm{aA} \\
0,01 \mathrm{aA}\end{array}$ & $\begin{array}{l}0,00 \mathrm{aA} \\
0,00 \mathrm{aB} \\
0,01 \mathrm{aB} \\
0,00 \mathrm{aA}\end{array}$ \\
\hline
\end{tabular}
diferem entre si ao nível de $5 \%$ de probabilidade pelo Teste de Tukey.

Na Tabela 30, pode-se observar que, curiosamente, estacas armazenadas por 60 dias em ambiente refrigerado obtiveram melhores resultados que estacas armazenadas por 30 dias. Uma das hipóteses é de que eram estacas com mais reserva que as outras, gerando brotos mais vigorosos. Assim mesmo a tendência se confirma, a de que menores períodos de armazenamento em condições refrigeradas tendem a resultar em menores perdas de qualidade 
das estacas, o que se confirma com a Tabela 31 da análise das médias das raízes, assim como na Tabela 32, onde apesar das diferenças praticamente não serem significativas, as médias dos rizomas também seguem o mesmo padrão.

\section{2. 4 Relação entre condições de armazenamento e tipos de recobrimento}

As Tabelas 33, 34 e 35 trazem as análises das médias dos números de brotos, raízes e rizomas, respectivamente, levando em conta as condições de armazenamento (ambiente refrigerado e temperatura ambiente) e tipos de recobrimento (FE, PV, PA, SP e SR), assim como suas respectivas massas de matéria fresca e seca.

Tabela 33. Médias do número de brotos desenvolvidos e suas respectivas massas de matéria fresca e seca, em gramas, observadas em estacas de outono de $C$. rubra, tratadas com 5 tipos de recobrimento e armazenadas em condições de temperatura ambiente ou sob refrigeração

\begin{tabular}{|c|c|c|c|}
\hline \multirow[b]{2}{*}{ Parâmetros } & \multirow[b]{2}{*}{$\begin{array}{c}\text { Tipo de } \\
\text { Recobrimento }\end{array}$} & \multicolumn{2}{|c|}{ Condição de Armazenamento } \\
\hline & & $\begin{array}{l}\text { Ambiente } \\
\text { Refrigerado }\end{array}$ & $\begin{array}{c}\text { Temperatura } \\
\text { Ambiente }\end{array}$ \\
\hline Número de Brotos & $\begin{array}{l}\text { FE } \\
\text { PV } \\
\text { PA } \\
\text { SP } \\
\text { SR }\end{array}$ & $\begin{array}{l}1,06 \mathrm{bA} \\
3,70 \mathrm{aA} \\
1,06 \mathrm{bA} \\
3,35 \mathrm{aA} \\
0,00 \mathrm{cA}\end{array}$ & $\begin{array}{l}0,16 \mathrm{bB} \\
2,00 \mathrm{aB} \\
0,15 \mathrm{bB} \\
2,00 \mathrm{aB} \\
0,00 \mathrm{bA}\end{array}$ \\
\hline $\begin{array}{l}\text { Massa de Matéria Fresca } \\
\qquad(\mathrm{g})\end{array}$ & $\begin{array}{l}\text { FE } \\
\text { PV } \\
\text { PA } \\
\text { SP } \\
\text { SR }\end{array}$ & $\begin{array}{c}2,19 \mathrm{bA} \\
7,40 \mathrm{aA} \\
2,01 \mathrm{bcA} \\
8,93 \mathrm{aA} \\
0,00 \mathrm{cA}\end{array}$ & $\begin{array}{l}0,14 \mathrm{bA} \\
4,54 \mathrm{aB} \\
0,06 \mathrm{bA} \\
4,39 \mathrm{aB} \\
0,00 \mathrm{bA}\end{array}$ \\
\hline $\begin{array}{l}\text { Massa de Matéria Seca } \\
\qquad(\mathrm{g})\end{array}$ & $\begin{array}{l}\text { FE } \\
\text { PV } \\
\text { PA } \\
\text { SP } \\
\text { SR }\end{array}$ & $\begin{array}{l}0,37 \mathrm{bA} \\
1,35 \mathrm{aA} \\
0,33 \mathrm{bA} \\
1,58 \mathrm{aA} \\
0,00 \mathrm{bA}\end{array}$ & $\begin{array}{l}0,01 \mathrm{bA} \\
0,81 \mathrm{aB} \\
0,00 \mathrm{bA} \\
0,74 \mathrm{aB} \\
0,00 \mathrm{bA}\end{array}$ \\
\hline
\end{tabular}


Tabela 34. Médias do número de raízes desenvolvidas e suas respectivas massas de matéria fresca e seca, em gramas, observadas em estacas de outono de C. rubra, tratadas com 5 tipos de recobrimento e armazenadas em condições de temperatura ambiente ou sob refrigeração

\begin{tabular}{|c|c|c|c|}
\hline \multirow[b]{2}{*}{ Parâmetros } & \multirow[b]{2}{*}{$\begin{array}{c}\text { Tipo de } \\
\text { Recobrimento }\end{array}$} & \multicolumn{2}{|c|}{ Condição de Armazenamento } \\
\hline & & $\begin{array}{l}\text { Ambiente } \\
\text { Refrigerado }\end{array}$ & $\begin{array}{l}\text { Temperatura } \\
\text { Ambiente }\end{array}$ \\
\hline Número de Raízes & $\begin{array}{l}\text { FE } \\
\text { PV } \\
\text { PA } \\
\text { SP } \\
\text { SR }\end{array}$ & $\begin{array}{c}2,23 \mathrm{bcA} \\
4,18 \mathrm{bA} \\
1,71 \mathrm{cdA} \\
9,08 \mathrm{aA} \\
0,00 \mathrm{dA}\end{array}$ & $\begin{array}{l}0,26 \mathrm{bA} \\
4,26 \mathrm{aA} \\
0,18 \mathrm{bA} \\
5,40 \mathrm{aB} \\
0,00 \mathrm{bA}\end{array}$ \\
\hline $\begin{array}{l}\text { Massa de Matéria Fresca } \\
\qquad(\mathrm{g})\end{array}$ & $\begin{array}{l}\text { FE } \\
\text { PV } \\
\text { PA } \\
\text { SP } \\
\text { SR }\end{array}$ & $\begin{array}{c}0,50 \mathrm{bA} \\
0,30 \mathrm{abA} \\
0,23 \mathrm{bcA} \\
1,18 \mathrm{aA} \\
0,00 \mathrm{cA}\end{array}$ & $\begin{array}{l}0,03 \mathrm{bB} \\
0,78 \mathrm{aA} \\
0,01 \mathrm{bA} \\
0,79 \mathrm{aA} \\
0,00 \mathrm{bA}\end{array}$ \\
\hline $\begin{array}{l}\text { Massa de Matéria Seca } \\
\qquad(\mathrm{g})\end{array}$ & $\begin{array}{l}\text { FE } \\
\text { PV } \\
\text { PA } \\
\text { SP } \\
\text { SR }\end{array}$ & $\begin{array}{c}0,07 \mathrm{bcA} \\
0,12 \mathrm{bA} \\
0,03 \mathrm{cA} \\
0,24 \mathrm{aA} \\
0,00 \mathrm{cA}\end{array}$ & $\begin{array}{l}0,00 \mathrm{bA} \\
0,11 \mathrm{aA} \\
0,00 \mathrm{bA} \\
0,09 \mathrm{aB} \\
0,00 \mathrm{bA}\end{array}$ \\
\hline
\end{tabular}

FE - fécula de mandioca; PV - parafina + vermiculita; PA - parafina no ápice; SP - saco plástico; SR - sem recobrimento

Médias seguidas de mesma letra (letras minúsculas na vertical; letras maiúsculas na horizontal, para cada item), não diferem entre si ao nível de $5 \%$ de probabilidade pelo Teste de Tukey.

$\mathrm{Na}$ Tabela 33, temos que os melhores resultados foram obtidos em ambiente refrigerado e os melhores tipos de recobrimento foram PV e SP, que são confirmados pelas médias de matéria fresca e seca dos brotos. Da mesma forma as Tabela 34 e 35, apresentam os resultados para raízes e rizomas desenvolvidos, que reforçam os resultados descritos anteriormente. 
Tabela 35. Médias do número de rizomas desenvolvidos e suas respectivas massas de matéria fresca e seca, em gramas, observadas em estacas de outono de $C$. rubra, tratadas com 5 tipos de recobrimento e armazenadas em condições de temperatura ambiente ou sob refrigeração

\begin{tabular}{|c|c|c|c|}
\hline \multirow[b]{2}{*}{ Parâmetros } & \multirow[b]{2}{*}{$\begin{array}{c}\text { Tipo de } \\
\text { Recobrimento }\end{array}$} & \multicolumn{2}{|c|}{ Condição de Armazenamento } \\
\hline & & $\begin{array}{l}\text { Ambiente } \\
\text { Refrigerado }\end{array}$ & $\begin{array}{l}\text { Temperatura } \\
\text { Ambiente }\end{array}$ \\
\hline Número de Rizomas & $\begin{array}{l}\text { FE } \\
\text { PV } \\
\text { PA } \\
\text { SP } \\
\text { SR }\end{array}$ & $\begin{array}{c}0,16 \mathrm{bcA} \\
0,35 \mathrm{abA} \\
0,06 \mathrm{cA} \\
0,63 \mathrm{aA} \\
0,00 \mathrm{cA}\end{array}$ & $\begin{array}{l}0,00 \mathrm{bA} \\
0,28 \mathrm{aA} \\
0,00 \mathrm{bA} \\
0,26 \mathrm{aB} \\
0,00 \mathrm{bA}\end{array}$ \\
\hline $\begin{array}{l}\text { Massa de Matéria Fresca } \\
\qquad(\mathrm{g})\end{array}$ & $\begin{array}{l}\text { FE } \\
\text { PV } \\
\text { PA } \\
\text { SP } \\
\text { SR }\end{array}$ & $\begin{array}{l}0,08 \mathrm{bA} \\
0,24 \mathrm{bA} \\
0,01 \mathrm{bA} \\
0,53 \mathrm{aA} \\
0,00 \mathrm{bA}\end{array}$ & $\begin{array}{l}0,00 \mathrm{aA} \\
0,19 \mathrm{aA} \\
0,00 \mathrm{aA} \\
0,19 \mathrm{aB} \\
0,00 \mathrm{aA}\end{array}$ \\
\hline $\begin{array}{l}\text { Massa de Matéria Seca } \\
\qquad(\mathrm{g})\end{array}$ & $\begin{array}{l}\text { FE } \\
\text { PV } \\
\text { PA } \\
\text { SP } \\
\text { SR }\end{array}$ & $\begin{array}{l}0,00 \mathrm{bA} \\
0,02 \mathrm{bA} \\
0,00 \mathrm{bA} \\
0,05 \mathrm{aA} \\
0,00 \mathrm{bA}\end{array}$ & $\begin{array}{l}0,00 \mathrm{aA} \\
0,02 \mathrm{aA} \\
0,00 \mathrm{aA} \\
0,01 \mathrm{aB} \\
0,00 \mathrm{aA}\end{array}$ \\
\hline
\end{tabular}

\section{2. 5 Relação entre tipos de recobrimento e períodos de armazenamento}

Nas Tabelas 36, 37 e 38, podem ser analisadas as médias dos números de brotos, raízes e rizomas, respectivamente, levando em conta os períodos de armazenamento $(30,60$, 90 ou 120 dias) e os tipos de recobrimento (FE, PV, PA, SP e SR), assim como suas massas de matéria fresca e seca. 
Tabela 36. Médias do número de brotos desenvolvidos e suas respectivas massas de matéria fresca e seca, em gramas, observadas em estacas de outono de $C$. rubra, tratadas com 5 tipos de recobrimento e armazenadas por 30,60,90 ou 120 dias

\begin{tabular}{|c|c|c|c|c|c|}
\hline \multirow[b]{2}{*}{ Parâmetros } & \multirow{2}{*}{$\begin{array}{c}\text { Tipo de } \\
\text { Recobrimento }\end{array}$} & \multicolumn{4}{|c|}{ Período de Armazenamento (dias) } \\
\hline & & 30 & 60 & 90 & 120 \\
\hline \multirow[t]{5}{*}{ Número de Brotos } & FE & $1,76 \mathrm{aB}$ & $0,70 a b C$ & $0,00 \mathrm{bB}$ & $0,00 \mathrm{bB}$ \\
\hline & PV & $2,26 \mathrm{bAB}$ & $3,53 \mathrm{aA}$ & $2,80 \mathrm{abA}$ & $2,80 \mathrm{abA}$ \\
\hline & PA & $1,36 \mathrm{aB}$ & $1,00 \mathrm{abC}$ & $0,06 \mathrm{bB}$ & $0,00 \mathrm{bB}$ \\
\hline & SP & 3,03 aA & $2,36 \mathrm{aB}$ & 3,00 aA & $2,30 \mathrm{aA}$ \\
\hline & SR & $0,00 \mathrm{aC}$ & $0,00 \mathrm{aC}$ & $0,00 \mathrm{aB}$ & $0,00 \mathrm{aB}$ \\
\hline \multirow{5}{*}{$\begin{array}{l}\text { Massa de Matéria Fresca } \\
\qquad(\mathrm{g})\end{array}$} & FE & $2,86 \mathrm{aAB}$ & $1,82 \mathrm{aB}$ & $0,00 \mathrm{aB}$ & $0,00 \mathrm{aB}$ \\
\hline & PV & $5,14 \mathrm{aA}$ & 8,12 aA & $4,90 \mathrm{aA}$ & $5,71 \mathrm{aA}$ \\
\hline & PA & $1,85 \mathrm{aAB}$ & $2,14 \mathrm{aB}$ & $0,14 \mathrm{aB}$ & $0,00 \mathrm{aB}$ \\
\hline & SP & $6,74 \mathrm{aA}$ & 7,79 aA & 6,49 aA & 5,61 aA \\
\hline & SR & $0,00 \mathrm{aB}$ & $0,00 \mathrm{aB}$ & $0,00 \mathrm{aB}$ & $0,00 \mathrm{aB}$ \\
\hline \multirow{5}{*}{$\begin{array}{c}\text { Massa de Matéria Seca } \\
\qquad(\mathrm{g})\end{array}$} & FE & $0,40 \mathrm{aBC}$ & $0,38 \mathrm{aC}$ & $0,00 \mathrm{aB}$ & $0,00 \mathrm{aB}$ \\
\hline & PV & $0,86 \mathrm{bAB}$ & $1,57 \mathrm{aA}$ & $0,87 \mathrm{bA}$ & $1,03 a b A$ \\
\hline & PA & $0,27 \mathrm{aBC}$ & $0,38 \mathrm{aC}$ & $0,02 \mathrm{aB}$ & $0,00 \mathrm{aB}$ \\
\hline & SP & $1,05 \mathrm{aA}$ & $1,45 \mathrm{aB}$ & $1,13 \mathrm{aA}$ & $1,01 \mathrm{aA}$ \\
\hline & SR & $0,00 \mathrm{aC}$ & $0,00 \mathrm{aC}$ & $0,00 \mathrm{aB}$ & $0,00 \mathrm{aB}$ \\
\hline
\end{tabular}

Tabela 37. Médias do número de raízes desenvolvidas e suas respectivas massas de matéria fresca e seca, em gramas, observadas em estacas de outono de C. rubra, tratadas com 5 tipos de recobrimento e armazenadas por $30,60,90$ ou 120 dias

\begin{tabular}{|c|c|c|c|c|c|}
\hline \multirow[b]{2}{*}{ Parâmetros } & \multirow{2}{*}{$\begin{array}{c}\text { Tipo de } \\
\text { Recobrimento }\end{array}$} & \multicolumn{4}{|c|}{ Período de Armazenamento (dias) } \\
\hline & & 30 & 60 & 90 & 120 \\
\hline \multirow[t]{5}{*}{ Número de Brotos } & FE & $3,30 \mathrm{aA}$ & $1,70 \mathrm{abB}$ & $0,00 \mathrm{bB}$ & $0,00 \mathrm{bC}$ \\
\hline & PV & $2,90 \mathrm{aA}$ & $4,90 \mathrm{aAB}$ & $4,16 \mathrm{aA}$ & $4,93 \mathrm{aB}$ \\
\hline & PA & $1,70 \mathrm{aAB}$ & $2,03 \mathrm{aB}$ & $0,06 \mathrm{aB}$ & $0,00 \mathrm{aC}$ \\
\hline & SP & $5,90 \mathrm{aA}$ & 7,70 aA & $6,90 \mathrm{aA}$ & $8,46 \mathrm{aA}$ \\
\hline & SR & $0,00 \mathrm{aB}$ & $0,00 \mathrm{aB}$ & $0,00 \mathrm{aB}$ & $0,00 \mathrm{aC}$ \\
\hline \multirow{5}{*}{$\begin{array}{l}\text { Massa de Matéria Fresca } \\
\qquad(\mathrm{g})\end{array}$} & FE & $0,72 \mathrm{aAB}$ & $0,25 \mathrm{abB}$ & $0,00 \mathrm{bB}$ & $0,01 \mathrm{bB}$ \\
\hline & PV & $0,56 \mathrm{aB}$ & 0,96 aA & $0,83 \mathrm{aA}$ & $1,01 \mathrm{aA}$ \\
\hline & PA & $0,26 \mathrm{aB}$ & $0,22 \mathrm{aB}$ & $0,01 \mathrm{aB}$ & $0,00 \mathrm{aB}$ \\
\hline & SP & $1,31 \mathrm{aA}$ & $1,07 \mathrm{aA}$ & $1,23 \mathrm{aA}$ & $1,06 \mathrm{bA}$ \\
\hline & SR & $0,00 \mathrm{aB}$ & $0,00 \mathrm{aB}$ & $0,00 \mathrm{aB}$ & $0,00 \mathrm{aB}$ \\
\hline \multirow{5}{*}{$\begin{array}{l}\text { Massa de Matéria Seca } \\
\qquad(\mathrm{g})\end{array}$} & FE & $0,09 \mathrm{aAB}$ & $0,06 \mathrm{aAB}$ & $0,00 \mathrm{aB}$ & $0,00 \mathrm{aB}$ \\
\hline & PV & $0,08 \mathrm{aAB}$ & $0,15 \mathrm{aA}$ & $0,13 \mathrm{aA}$ & $0,11 \mathrm{aAB}$ \\
\hline & PA & $0,03 \mathrm{aB}$ & $0,03 \mathrm{aAB}$ & $0,00 \mathrm{aB}$ & $0,00 \mathrm{aB}$ \\
\hline & SP & 0,18 aA & 0,15 aA & $0,15 \mathrm{aA}$ & $0,18 \mathrm{aA}$ \\
\hline & SR & $0,00 \mathrm{aB}$ & $0,00 \mathrm{aB}$ & $0,00 \mathrm{aB}$ & $0,00 \mathrm{aB}$ \\
\hline
\end{tabular}


Tabela 38. Médias do número de rizomas desenvolvidos e suas respectivas massas de matéria fresca e seca, em gramas, observadas em estacas de outono de $C$. rubra, tratadas com 5 tipos de recobrimento e armazenadas por 30,60,90 ou 120 dias

\begin{tabular}{|c|c|c|c|c|c|}
\hline \multirow[b]{2}{*}{ Parâmetros } & \multirow{2}{*}{$\begin{array}{c}\text { Tipo de } \\
\text { Recobrimento }\end{array}$} & \multicolumn{4}{|c|}{ Período de Armazenamento (dias) } \\
\hline & & 30 & 60 & 90 & 120 \\
\hline \multirow[t]{5}{*}{ Número de Brotos } & FE & $0,20 \mathrm{aAB}$ & $0,13 \mathrm{aAB}$ & $0,00 \mathrm{aA}$ & $0,00 \mathrm{aAB}$ \\
\hline & PV & $0,26 \mathrm{aAB}$ & $0,36 \mathrm{aAB}$ & $0,36 \mathrm{aA}$ & $0,26 \mathrm{aAB}$ \\
\hline & PA & $0,10 \mathrm{aAB}$ & $0,03 a A B$ & $0,00 \mathrm{aA}$ & $0,00 \mathrm{aAB}$ \\
\hline & SP & $0,50 \mathrm{aA}$ & $0,46 \mathrm{aA}$ & $0,36 \mathrm{aA}$ & $0,46 \mathrm{aA}$ \\
\hline & SR & $0,00 \mathrm{aB}$ & $0,00 \mathrm{aB}$ & $0,00 \mathrm{aA}$ & $0,00 \mathrm{aB}$ \\
\hline \multirow{5}{*}{$\begin{array}{l}\text { Massa de Matéria Fresca } \\
\qquad(\mathrm{g})\end{array}$} & FE & $0,08 \mathrm{aA}$ & $0,08 \mathrm{aA}$ & $0,00 \mathrm{aB}$ & $0,00 \mathrm{aA}$ \\
\hline & PV & $0,07 \mathrm{aA}$ & $0,22 \mathrm{aA}$ & $0,42 \mathrm{aA}$ & $0,15 \mathrm{aA}$ \\
\hline & PA & $0,02 \mathrm{aA}$ & $0,00 \mathrm{aA}$ & $0,00 \mathrm{aB}$ & $0,00 \mathrm{aA}$ \\
\hline & SP & $0,24 \mathrm{aA}$ & $0,40 \mathrm{aA}$ & 0,46 aA & $0,35 \mathrm{aA}$ \\
\hline & SR & $0,00 \mathrm{aA}$ & $0,00 \mathrm{aA}$ & $0,00 \mathrm{aB}$ & $0,00 \mathrm{aA}$ \\
\hline \multirow{5}{*}{$\begin{array}{l}\text { Massa de Matéria Seca } \\
\qquad(\mathrm{g})\end{array}$} & $\mathrm{FE}$ & $0,00 \mathrm{aA}$ & $0,01 \mathrm{aA}$ & $0,00 \mathrm{aB}$ & $0,00 \mathrm{aA}$ \\
\hline & PV & $0,00 \mathrm{aA}$ & $0,01 \mathrm{aA}$ & $0,04 \mathrm{aA}$ & $0,01 \mathrm{aA}$ \\
\hline & PA & $0,00 \mathrm{aA}$ & $0,00 \mathrm{aA}$ & $0,00 \mathrm{aB}$ & $0,00 \mathrm{aA}$ \\
\hline & SP & $0,02 \mathrm{aA}$ & $0,04 \mathrm{aA}$ & $0,04 \mathrm{aA}$ & $0,03 \mathrm{aA}$ \\
\hline & SR & $0,00 \mathrm{aA}$ & $0,00 \mathrm{aA}$ & $0,00 \mathrm{aB}$ & $0,00 \mathrm{aA}$ \\
\hline
\end{tabular}

$\mathrm{Na}$ Tabela 36, podemos observar que os melhores resultados foram obtidos em períodos de armazenamento mais curtos, 30 a 60 dias e que as maiores médias dos números de brotos estão nos tipos de recobrimento PV e SP. Em relação às raízes (Tabela 37), ocorre a confirmação dos resultados obtidos na tabela anterior, com pequenas variações, mas as tendências seguem na Tabela 38 com os rizomas, quando presentes.

É possível se dizer também que os métodos mais eficientes de recobrimento para se obter um bom enraizamento após o armazenamento são: a embalagem em saco plástico (SP), o recobrimento da parte apical com pasta de parafina fundida e parte basal em vermiculita umedecida (PV), se destacando dos demais tipos de recobrimento. Esses tipos de recobrimento são indicados para armazenamentos com períodos mais elevados.

Os resultados encontrados com o recobrimento com parafina confirmam aqueles descritos por Chitarra \& Chitarra (1990), quanto a redução na perda de água e diminuição no enrugamento do material. Cardoso (1961), encontrou resultados semelhantes onde estacas de seringueira, mantiveram suas melhores características quando recobertas com parafina. Silva \& Lopes (1993), em seu experimento de conservação de ramas de batata-doce (Ipomoea batatas), observou que o recobrimento com parafina não impediu a troca gasosa entre as ramas e o meio ambiente, pois foi observada uma crescente perda de peso no decorrer do período de armazenamento, mas a perda de umidade foi mais lenta para as estacas recobertas em relação às estacas sem recobrimento, mantendo assim a qualidade fisiológica do material. $\mathrm{O}$ autor 
observou também que as estacas armazenadas por 16 dias, sem recobrimento perderam a capacidade de gerar novas plantas, enquanto que o recobrimento com parafina, manteve suas qualidades fisiológicas.

No presente trabalho, o método que emprega a embalagem das estacas em saco plástico, quando combinado com o armazenamento em ambiente refrigerado, apresentou resultados muito bons, fazendo com que as estacas pudessem ser armazenadas por longos períodos de tempo (no caso 120 dias) e ainda assim, enraizassem de forma similar às testemunhas, que foram colocadas em leito de enraizamento sem passar pelo período de armazenamento.

Resultados semelhantes foram encontrados por Reis (1998) em seu experimento com estacas de Polyscias guilfoylei Bailey, envolvendo diversos tipos de recobrimento, entre eles, a embalagem em saco plástico, recobrimento da parte apical com pasta de parafina fundida e base em vermiculita umedecida, que obtiveram destaque por manterem a qualidade das estacas, promovendo um bom enraizamento após determinados períodos de armazenamento (30, 60 e 90 dias).

Flint \& Macguire (1960), conseguiram até 100\% de sobrevivência das estacas de várias espécies de ornamentais (Forsythia intermedia "Lynwood Gold", Juniperus chinensis glauca Hetzi, Pachistima canbyi, Thuja orientalis aurea nana, Weigela "Vanicekii", Hibiscus syriacus "Lady Stanley" e Rhododendron obtusum "Sherwood Red"), após 4 meses de armazenamento com a utilização de saco plástico, mas quando estendido para 6 meses, houve declínio.

Reis et al.(1997), recomendam ainda o uso da embalagem em sacos plásticos para estacas de Polyscias guilfoylei Bailey, por não diferirem estatisticamente do recobrimento com parafina e devido a sua praticidade. Ainda devido à esta última, produtores de mudas de crisântemo, utilizam rotineiramente o saco plástico como embalagem.

Observou-se no presente trabalho que o uso da película a base de fécula de mandioca não trouxe os resultados esperados, apresentando resultados que não foram satisfatórios, sendo muitas vezes mais baixos que o tratamento testemunha, não sendo recomendados, como no recobrimento de frutos.

Em estacas armazenadas por mais de 30 dias, embaladas em sacos plásticos, em temperatura ambiente, observou-se a presença de estruturas fúngicas apesar do tratamento químico de desinfestação. Mas não houveram prejuízos às estacas, que enraizaram de forma satisfatória. O único problema que poderia ocorrer seria a apresentação do produto, no caso, a estaca.

Deve-se salientar também que o efeito da temperatura de armazenamento das estacas foi fundamental para os bons resultados dos tratamentos acima descritos. As baixas temperaturas conservaram melhor as características das estacas em todos os tratamentos. 
Em estacas de abacateiro (Persea americana) Jubes \& Foguet (1971) mantiveram sua viabilidade quando conservados em sacos de polietileno a temperatura de 3 a $5^{\circ} \mathrm{C}$. Flint \& Macguire (1960) relatam grande variabilidade da qualidade de estacas de diversas plantas, quando variadas as temperaturas de armazenamento. Pryor et al. (1963), também obtiveram bons resultados de enraizamento de estacas de azaléias, após armazenamento refrigerado, por até 4 semanas.

Em seu trabalho, Reis (1998) concluiu que para estacas de Polyscias guilfoylei coletadas na primavera (setembro) apresentaram maiores percentagens de enraizamento, do que quando coletadas no inverno (junho). Estacas de Bougainvillea spectabilis coletadas no inverno, apresentaram baixas percentagens de enraizamento.

Confirmando o experimento de Reis (1998), em seu trabalho com estacas de espécies lenhosas de plantas, os resultados do presente trabalho, mostram que estacas de C. rubra recobertas por películas, coletadas em primavera apresentaram melhores percentagens de enraizamento do que estacas coletadas no outono. Neste experimento, a coleta das estacas de outono, foi realizada algumas semanas antes do início do inverno.

Outro resultado interessante, é que as estacas recobertas pela película amilácea não apresentaram resultados satisfatórios após os 30 dias de armazenamento, onde, por muitas vezes o tratamento não diferiu das estacas sem recobrimento. Em seus trabalhos, Kavamura et al. (2002), mostraram que hastes de rosa recobertas com películas de amido CMA apresentaram melhores resultados de pós-colheita quando não submetidas ao ambiente refrigerado, enquanto que em hastes mantidas em ambiente refrigerado, os melhores resultados foram observados, com o uso da película a base de cera de carnaúba. Embora Ferraz (2000), em seu trabalho com hastes florais de rosa, concluiu que as hastes duraram apenas 4 dias em condições de comercialização; as hastes tratadas com o filme amiláceo não diferiram da testemunha e o processo de senescência das flores, que continuou normalmente, consumindo principalmente açúcares, perdendo massa e peroxidase. 


\section{CONCLUSÕES}

\section{1 Estacas de C. rubra obtidas na primavera}

Até 30 dias, todos os tratamentos para estacas armazenadas em ambiente refrigerado e PA/A e SP/A para estacas mantidas em temperatura ambiente são recomendados para se obter um bom enraizamento e um bom desenvolvimento de parte aérea. Quanto aos rizomas, todos os tratamentos mostraram um bom desenvolvimento.

Para 60 dias de armazenamento, apenas PV/R e PA/R são recomendados para um bom enraizamento e desenvolvimento de parte aérea. Para o desenvolvimento de rizomas, todos os tratamentos podem ser recomendados, exceto FE/A e SR/A.

Para 90 dias, recomenda-se apenas SP/R para um bom desenvolvimento e um bom enraizamento. Rizomas surgiram em todos os tratamentos exceto em SR/R, FE/A, PA/A e SR/A.

Para 120 dias de armazenamento, nenhum tratamento é recomendado para se obter um bom enraizamento e desenvolvimento de parte aérea. Para o desenvolvimento de rizomas, apenas PV/R, SP/R e PV/A podem recomendados, por manterem suas características fisiológicas.

\section{2 Estacas de C. rubra obtidas no outono}

Para 30 dias de armazenamento, os tratamentos FE/R, SP/R e SP/A são indicados para se obter um bom enraizamento, enquanto que para um bom desenvolvimento de parte aérea $\mathrm{e}$ formação de rizomas são indicados apenas SP/R e SP/A.

Para 60 dias de armazenamento, apenas PV/R e SP/R são recomendados para um bom enraizamento e para um bom desenvolvimento de parte aérea e de rizomas, indica-se PV/R e SP/R. 
Para 90 dias, recomenda-se PV/R e SP/R para um bom desenvolvimento de parte aérea e um bom enraizamento. Por apresentarem boa formação de rizomas o tratamento $S R / R$ é recomendado.

Em 120 dias de armazenamento, somente os tratamentos PV/R e SP/R são recomendados para se obter bons enraizamentos e bom desenvolvimento de parte aérea. Para o desenvolvimento de rizomas, apenas SP/R é satisfatório.

\section{3 Conclusões gerais}

As estacas de C. rubra, coletadas na primavera apresentaram maiores porcentagens de enraizamento do que quando coletadas no outono.

O emprego da película a base de fécula de mandioca se mostrou viável apenas para conservação das estacas por no máximo 30 dias, não importando a temperatura de armazenamento. Os melhores resultados foram sempre obtidos com o emprego de sacos plásticos ou parafina no ápice e vermiculita umedecida na base das estacas. Nesses tipos de recobrimento, a qualidade das estacas foi mantida por mais tempo.

A utilização do ambiente refrigerado como método de conservação de estacas de $C$. rubra é válida para as duas épocas estudadas (primavera e outono) por manter por mais tempo a viabilidade de enraizamento das estacas.

As porcentagens de enraizamento, desenvolvimento de parte aérea e rizomas bem como produção de matéria fresca e seca de parte aérea, raízes e rizomas diminuíram com o aumento do tempo de armazenamento em ambas as épocas de coleta.

Vale ressaltar que para fins práticos, a embalagem das estacas em saco plástico se mostrou mais fácil do que os outros tipos de recobrimento, que no caso da aplicação da película amilácea e a aplicação de parafina, era necessário o uso de uma fonte de calor, e a vermiculita umedecida se mostrou muito trabalhosa no processo de embalagem individual.

Com a utilização dos tipos de recobrimento acima citados, aliados ao acondicionamento em baixas temperaturas, é possível transportar as estacas de C. rubra por outros modais que não o aéreo, como é realizado atualmente em sua exportação, reduzindo custos, mantendo suas características e atendendo o consumidor da melhor forma possível. 


\section{REFERÊNCIAS BIBLIOGRÁFICAS}

AKI, A. Y. O sistema Veiling na comercialização de hortifrutigranjeiros. Holambra: Primon, 1996. 80p.

ANEFALOS, L. C. Modelo insumo-produto como instrumento de avaliação econômica da cadeia de suprimentos: $O$ caso da exportação de flores de corte. Piracicaba, 2004. 210p. Tese (Doutorado) - Escola Superior de Agricultura "Luiz de Queiróz”, Universidade de São Paulo.

ARRUDA, S. T. Diagnóstico da floricultura do Estado de São Paulo. Revista Brasileira de Horticultura Ornamental, v.2, n.2, p.1-18, 1996.

AWORH, O. C.; NWANKWO, C. F.; OLORUNDA, A. O. Control of post-harvest losses in citrus fruits under tropical conditions: effects of wax and fungicide. Tropical Science, v.31, n.2, p.177-182, 1991.

BONGERS, F. A economia das flores. Agroanalysis, v.15, p.1-4, 1995.

CARDOSO, M. Conservação de hastes de seringueira destinadas a enxertia. Bragantia, v.20, p.53-56, ago., 1961.

CHITARRA, M. I. F; CHITARRA, A. B. Pós-Colheita de Frutos e Hortaliças: Fisiologia e Manuseio. Lavras: ESAL/FAEP, 1990. 320p.

CHUN, D.; MILLER, W. R.; RISSE, L. A. Benefits of post-harvest applications of a biocide (thiabendazole) and coatings on the storage of "Minneola" tangelos. Tropical Science, v.30, n.3, p.241-248, 1990.

DARVAS, J. M.; KOTZE, J. M.; WEHNER, F. C. Effect of treatment after picking on the incidence of post-harvest fruit diseases of avocado. Phytophylactica, v.22, n.1, p.93-96, 1990. 
EDWARDS, M. E.; BLENNERHASSETT, R. M. The use of postharvest treatments to extend storage life and to control postharvest wastage of honeydew melons (Cucumis melo L. var inodorus Naud.) in cool storage. Australian Journal of Experimental Agriculture, v.30, n.5, p.693-697, 1990.

FERRAZ, M. V. Avaliação da utilização de películas amiláceas na conservação pós-colheita de rosa (Rosa hybrida var. Grand Galla). Botucatu, 2000. 77p. Dissertação (M.S.) - Faculdade de Ciências Agronômicas, Universidade Estadual Paulista “Júlio de Mesquita Filho".

FLINT, H. L.; McGUIRE. Overwinter refrigerated storage of rooted cuttings. Rhode Island Nurseryman's Newsletter, n.3, p.5-8, 1960.

GRAF, A. B. Tropica: color cyclopedia of exotic plants and trees. 4.ed. East Rutherford: Roehrs, 1992. 1152p.

GROOT, E. Avaliação econômica da produção de rosa de corte (Rosa sp.), em campo e em estufa, sob condições de risco, no município de Holambra - SP: Estudo de casos. Piracicaba, 2003. 78p. Dissertação (Mestrado) - Escola Superior de Agricultura "Luiz de Queiróz", Universidade de São Paulo.

GUPTA, S. K.; GUPTA, G. K. Role of pre-harvest fungicidal sprays and post-harvest wax coating against sooty blotch, fly speck and storage rots of apple. Plant Disease Research, v.7, n.2, p.161-164, 1992.

HAMRICK, D. A produção de flores no mercado. Ibraflor. Boletim Informativo, n.11, p.4-5, Jun. 1996.

HATA, T. Y.; HARA, A. H.; NAGAO, M. A.; HU, B. K. S. Hot-water treatment and indole-3-butyric acid stimulates rooting and shoot development of tropical ornamental cuttings. HortTechnology, v.4, n.2, p.159-162, 1994.

HENRIQUE, C. M. Utilização de ethephon e película de fécula de mandioca na conservação pós-colheita de limão siciliano (Citrus limon (Linn) Burn). Botucatu, 1999. 161p. Dissertação (M.S.) - Faculdade de Ciências Agronômicas, Universidade Estadual Paulista "Júlio de Mesquita Filho".

JUQUIÁ: Informações. http://www.valedoribeira.com.br/juquia/informacoes/index.asp (23 mar. 2005) 
JUNQUEIRA, A. H.; PEETZ, M. S. Os pólos de produção de flores e plantas ornamentais no Brasil: Uma análise do potencial exportador. Revista Brasileira de Horticultura Ornamental, v.8, n.1/2, p.25-47, 2002.

KAVAMURA, H. E.; SAKAMOTO, N. M.; OLIVEIRA, M. J. G.; RIBEIRO, R. C. S.; CEREDA, M. P. Películas flexíveis e seus efeitos na conservação pós-colheita de hastes florais de rosa armazenadas sob diferentes períodos de refrigeração. Piracicaba, 2002. 32p. Relatório (Estágio Supervisionado) - Escola Superior de Agricultura "Luiz de Queiroz". Universidade de São Paulo.

LAMAS, A. M. Floricultura tropical: técnicas de cultivo. Recife: SEBRAE/PE, 2001. 87p.

LAWS, N. Colômbia e o mercado americano. Ibraflor. Boletim Informativo, n.15, p.6, Mar. 1997.

LORENZI, H.; SOUZA, H. M. Plantas ornamentais no Brasil: arbustivas, herbáceas e trepadeiras. Nova Odessa: Editora Plantarum, 1999. 1088p.

MATSUNAGA, M. Floricultura como alternativa econômica na agricultura. Informações Econômicas, v.25, p.94-98, 1995.

OLIVEIRA, M. A. Utilização de película de fécula de mandioca como alternativa à cera comercial na conservação pós-colheita de frutos de goiaba (Psidium guajava). Piracicaba, 1996. 73p. Dissertação (Mestrado) - Escola Superior de Agricultura "Luiz de Queiroz", Universidade de São Paulo.

OLIVETTI, M. P. A.; TAKAES, M.; MATSUNAGA, M. Perfil da produção das principais flores de corte no Estado de São Paulo. Informações Econômicas, v.24, n.7, p.31-54, 1994.

PEROSA, J. M. Y. Participação brasileira no mercado internacional de flores e plantas ornamentais. Revista Brasileira de Horticultura Ornamental, v.8, n.1/2, p.1-11, 2002.

POOLE, R. T.; CONOVER, C. A. Effect of storage position on growth of Dracaena fragans "Massangeana" cane. Proceedings of the Interamerican Society for Tropical Horticulture, v.36, p.118-122, 1992.

PRYOR, R. L.; STEWART, R. L. Storage of unrooted azalea cuttings. American Society for Horticultural Science, v.82, p.483-484, 1963. 
REIS, S. D. A. Efeitos dos tratamentos e do armazenamento no enraizamento de estacas de Polyscias guilfoylei Bailey (Árvore da felicidade) e de Bougainvillea spectabilis Willd. (Primavera). Ilha Solteira, 1998. 92p. Monografia (Graduação) - Universidade Estadual Paulista "Júlio de Mesquita Filho".

REIS, S. D. A.; RIBEIRO, R. C. S.; FABRI, E. G.; BOLIANI, A. C.; SOUZA, M. A. L. B. Armazenamento de estacas de árvore da felicidade (Polyscias guilfoylei). /Apresentado ao XI Congresso Brasileiro de Floricultura e Plantas Ornamentais, Pará, 1997/

SOUZA, L. H. Armazenamento de hastes de porta-enxerto de seringueiras (Hevea brasiliensis, Muell \& Arg.) "clone RRIM 600". Lavras, 1990. 43p. Dissertação (Mestrado) - Escola Superior de Agricultura de Lavras.

SILVA, J. B. C.; LOPES, C. A. Uso de parafina na conservação de ramas de batata-doce. Horticultura Brasileira, v.11, n.1,p.25-26, 1993.

SNYDER, W. E.; HESS, C. E. Low temperature storage of rooted cuttings of nursery crops. American Society for Horticultural Science, v.67, p.545-548, 1956.

TARKASE, B. G.; DESAI, U. T. Effects of packaging and chemicals on storage of orange cv. Mosambi. Journal of Maharshtra Agricultural Universities, v.14, n.1, p.10-13, 1989.

TEIXEIRA, S. L.; ANDERSEN, O.; CARDINALLI, L. R. Influência do período pós-colheita das hastes de citrus, sobre a qualidade das borbulhas para a exertia. Revista CERES, v.18, n.99, p.406-417, 1971.

VICENTINI, N. M. Utilização de películas de fécula de mandioca para a conservação póscolheita de couve-flor (Brassica oleraceae var. botrytis). Botucatu, 1999. 85p. Dissertação (Mestrado) - Faculdade de Ciências Agronômicas, Universidade Estadual Paulista "Júlio de Mesquita Filho".

VIETES, R. L.; DAUTO, A. R.; BONASSI, I. A. Efeito da utilização de cera e películas de amido e fécula em condições de refrigeração na conservação do tomate. In: CONGRESSO BRASILEIRO DE CIÊNCIA E TECNOLOGIA DE ALIMENTO, 15., Poços de Caldas, 1996. Resumos. Poços de Caldas, sbCTA. 1996, p.157.

ZAFALON, M. Temporada de flores trás empregos e renda. Folha de São Paulo. Agrofolha, São Paulo, 09 set. 2003. p.B-10. 